\title{
Stream Salamander And Benthic Macroinvertebrate Community Responses To Imidacloprid Exposure
}

\author{
Sara M. Crayton \\ WVU, sc0038@mix.wvu.edu
}

Follow this and additional works at: https://researchrepository.wvu.edu/etd

Part of the Environmental Sciences Commons

\section{Recommended Citation}

Crayton, Sara M., "Stream Salamander And Benthic Macroinvertebrate Community Responses To Imidacloprid Exposure" (2019). Graduate Theses, Dissertations, and Problem Reports. 4015.

https://researchrepository.wvu.edu/etd/4015

This Thesis is protected by copyright and/or related rights. It has been brought to you by the The Research Repository @ WVU with permission from the rights-holder(s). You are free to use this Thesis in any way that is permitted by the copyright and related rights legislation that applies to your use. For other uses you must obtain permission from the rights-holder(s) directly, unless additional rights are indicated by a Creative Commons license in the record and/ or on the work itself. This Thesis has been accepted for inclusion in WVU Graduate Theses, Dissertations, and Problem Reports collection by an authorized administrator of The Research Repository @ WVU. For more information, please contact researchrepository@mail.wvu.edu. 


\title{
STREAM SALAMANDER AND BENTHIC MACROINVERTEBRATE COMMUNITY RESPONSES TO IMIDACLOPRID EXPOSURE
}

\author{
Sara M. Crayton \\ Thesis submitted \\ to the Davis College of Agriculture, Natural Resources and Design \\ at West Virginia University \\ in partial fulfillment of the requirements for the degree of \\ Master of Science \\ in Wildlife and Fisheries Resources
}

\author{
Petra B. Wood, Ph.D., chair \\ Donald J. Brown, Ph.D., co-chair \\ Yong-Lak Park, Ph.D. \\ Division of Forestry and Natural Resources, \\ Wildlife and Fisheries Resources Program
}
Morgantown, West Virginia
2019

Keywords: Imidacloprid, neonicotinoid, headwater stream communities, bioaccumulation, hemlock woolly adelgid, benthic macroinvertebrates, stream salamanders

(C) Sara Crayton 2019 


\begin{abstract}
Stream Salamander and Benthic Macroinvertebrate Community Responses to Imidacloprid Exposure
\end{abstract}

Sara M. Crayton

In this study, I investigated whether the usage of a common insecticide for forest conservation has non-target effects on stream organisms. Hemlock woolly adelgid (HWA; Adelges tsugae) is an invasive insect that has caused wide-spread loss of hemlock trees in the eastern United States. Imidacloprid is a neonicotinoid insecticide and is the most widely used treatment to mitigate hemlock mortality from HWA infestations, but application of imidacloprid can result in lethal and sublethal effects on non-target taxa. I assessed non-target effects of HWA treatments using imidacloprid on benthic macroinvertebrates and stream salamanders in central West Virginia.

In Chapter 1, I provide a literature review of the impact of HWA on forest systems and known non-target effects of HWA treatments on benthic macroinvertebrates and amphibians. I also review studies that investigated bioaccumulation of imidacloprid in amphibians and other taxa.

In Chapter 2, I assess whether stream salamanders or benthic macroinvertebrates bioaccumulate imidacloprid or imidacloprid metabolites through exposure to HWA treatments. I also evaluate relationships between imidacloprid bioaccumulation and exposure and sublethal effects in salamanders, including corticosterone hormone levels and body condition indices. Of 107 stream salamanders, 29 individuals had detectable levels of imidacloprid $(n=14)$ and/or imidacloprid-olefin $(n=19)$ in their tissues. Of 15 stream invertebrate samples, 15 had detectable levels of imidacloprid and 13 had detectable levels of imidacloprid-urea in their tissues.

Corticosterone levels increased with increasing numbers of imidacloprid applications and body condition decreased as water imidacloprid concentration increased. Our study demonstrates that stream salamanders and invertebrates can bioaccumulate imidacloprid from HWA treatments and imidacloprid exposure likely has sublethal effects on stream salamanders.

In Chapter 3, I evaluate whether abundances of five stream salamander species are affected by imidacloprid presence. We surveyed stream salamanders 5-7 times at 48 sites, 27 of 
which were directly adjacent to HWA treatments. We used $N$-mixture models and a model selection approach to identify important predictors of abundance for Desmognathus fuscus, D. monticola, D. ochrophaeus, Eurycea spp., and Gyrinophilus porphyriticus. We identified influential detection and habitat variables for each species and then tested models containing imidacloprid predictors. For all species, there was support for models containing predictors of imidacloprid exposure. Number of imidacloprid treatments and presence of environmental imidacloprid had a negative relationship with Desmognathus spp. abundances, but we did not detect negative effects of imidacloprid exposure on Eurycea spp. or G. porphyriticus.

In Chapter 4, I evaluate whether imidacloprid exposure affects benthic macroinvertebrate communities in the Monongahela National Forest and two units of the National Park Service in West Virginia. We sampled benthic macroinvertebrates from 47 sites, 26 of which were directly adjacent to HWA treatments. We calculated seven benthic macroinvertebrate community metrics and then compared those indices to four imidacloprid predictors with linear or beta regressions. There was support for effects of imidacloprid exposure on all community metrics, and the relationship between community metrics and imidacloprid differed by locality with GLIMPSS and WVSCI being lower in the Monongahela National Forest in sites with imidacloprid exposure. Additionally, we compared functional traits of benthic macroinvertebrate communities to metrics of imidacloprid exposure. Functional traits analysis showed no significant differences in community functional traits composition between sites with or without imidacloprid presence, and with or without treated trees. Variation in functional traits was higher in sites in MNF with environmental imidacloprid exposure, indicating that some functional traits may be lost from streams with imidacloprid. We conclude that usage of imidacloprid is likely negatively impacting benthic macroinvertebrate communities in MNF.

The goal of this thesis was to inform forest managers about potential non-target concerns in stream organisms exposed to HWA treatments. We detected sublethal effects and population effects in Desmognathus spp. and effects on benthic macroinvertebrate communities in MNF. Overall, this study has demonstrated that stream organisms in West Virginia may be at risk from HWA treatments. 


\section{ACKNOWLEDGMENTS}

I firstly would like to acknowledge the support and guidance of my advisor Dr. Wood, my cochair Dr. Brown, and my committee member Dr. Park over the past 2+ years. I am thankful to the U.S. Geological Survey-National Park Service Water Quality Partnership Program, the West Virginia University Program to Stimulate Competitive Research, and the Foundation for the Conservation of Salamanders for providing funding and support for this project. I also appreciate the West Virginia Department of Natural Resources, National Park Service, and the USGS WV Cooperative Fish and Wildlife Research Unit for supporting this project and providing logistical support. I appreciate Dr. Christine Arnott and John Perez for helping with project development and funding. Many thanks go to John Perez, Layne Strickler, and Lenza Paul for assistance with site selection and information on treatment histories. Alice Millikin was a vital contributor with corticosterone research. Dr. Terrance McManus, Dr. Kang Mo Ku, Dr. Kim, and Tyler Simpson provided important assistance with chemical analyses. Thank you to Kevin Eliason and Dr. Matthew McKinney for their contribution with benthic analyses. Thank you to Brian Carlson for contributing his skills in benthic invertebrate identification and thank you to George Merovich for assistance with biomass calculations. Thank you to Justin Hatcher for allowing us access to his private property. The contributions of my technicians and volunteers, Devin Hoffer, Kait Sudol, Allison Fulcher, Sam Wilson, Zachary Dienes, Eliana Henriquez, Monisha Mahalaha, Tyler Sylvester, Allie Brabham, and Jamie Saunders, are invaluable. Finally, I am exceedingly thankful for the friendship of my labmates and for the loving support of my friends and family over the past several years. 


\section{TABLE OF CONTENTS}

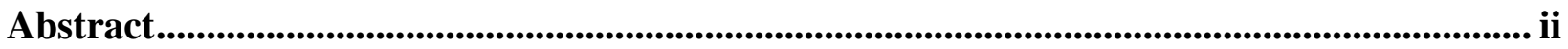

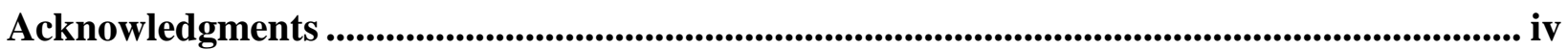

Table of Contents .............................................................................................................................v

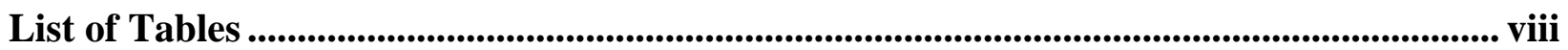

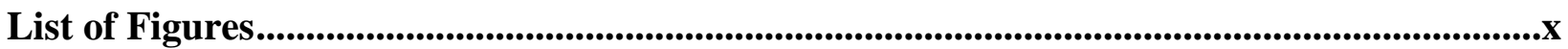

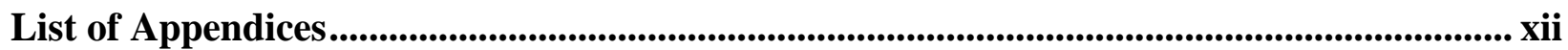

Chapter 1. Introduction and Literature Review.....................................................................................1

1. Impact of hemlock woolly adelgid on hemlock forests .....................................................

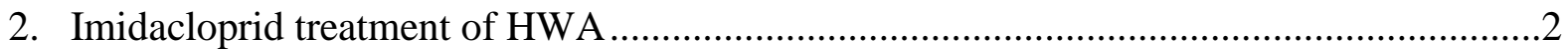

3. Leaching of imidacloprid into aquatic systems ..............................................................

4. Ecological consequences of imidacloprid treatment on

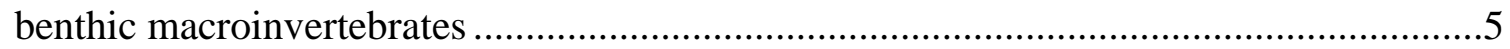

5. Observed and potential impacts of imidacloprid exposure on amphibians .........................6

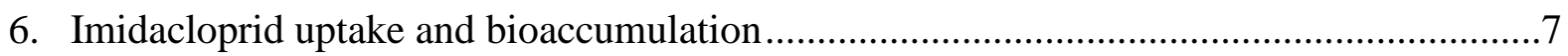

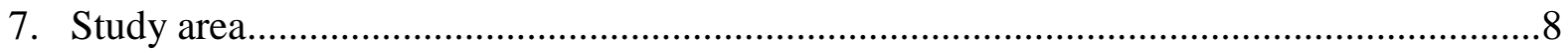

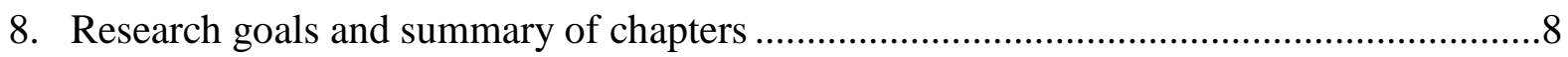

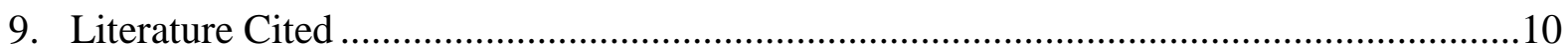

\section{Chapter 2. Bioaccumulation of the Pesticide Imidacloprid in Stream Organisms and}

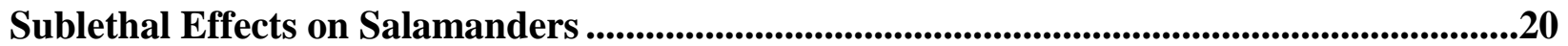

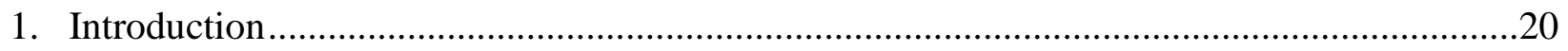

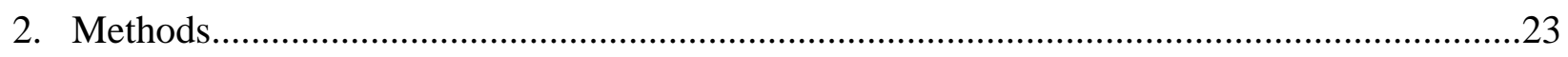

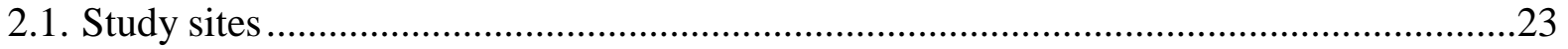

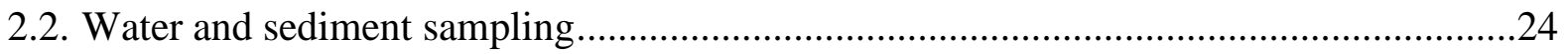

2.3. Water and sediment imidacloprid extraction and quantification ......................................25

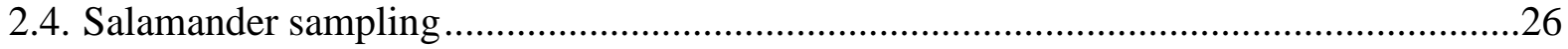

2.5. Salamander sampling for corticosterone concentration

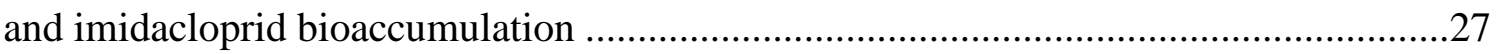


2.6. Benthic macroinvertebrate and crayfish sampling ............................................27

2.7. Salamander and invertebrate imidacloprid extraction and quantification ......................28

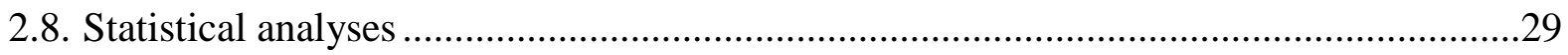

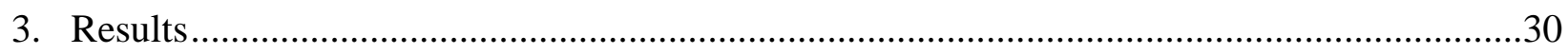

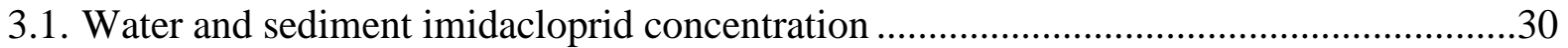

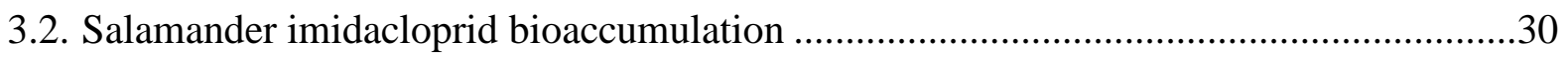

3.3. Benthic macroinvertebrate and crayfish imidacloprid bioaccumulation .........................31

3.4. Sublethal effects of imidacloprid on salamanders .................................................. 31



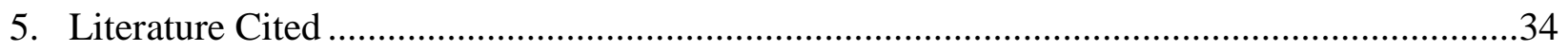

Chapter 3. Effects of Imidacloprid Exposure on Stream Salamander Abundances ..............63

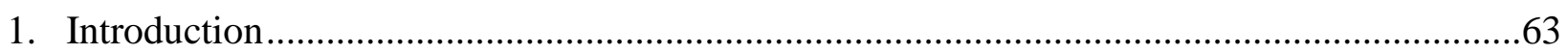

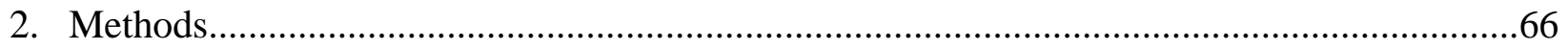

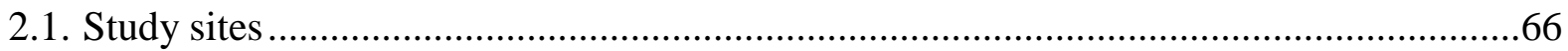

2.2. Water and sediment imidacloprid extraction and quantification ...............................66

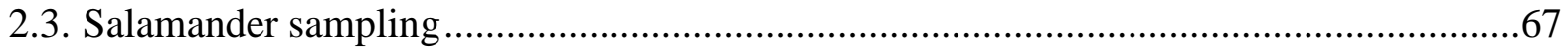

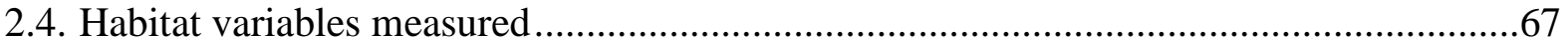

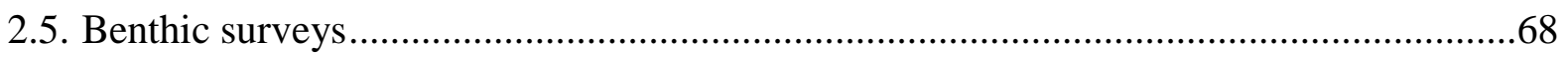

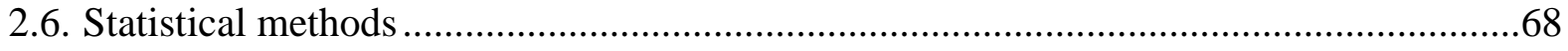

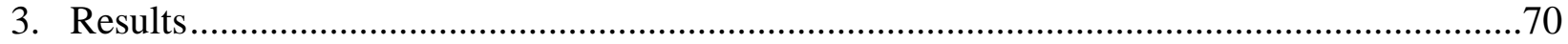

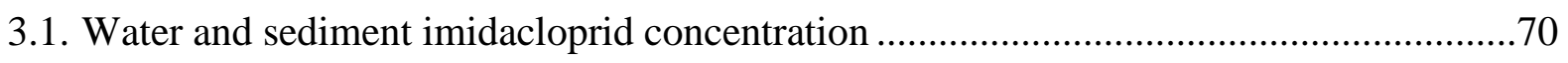

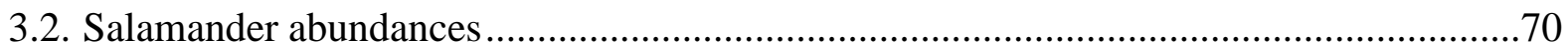

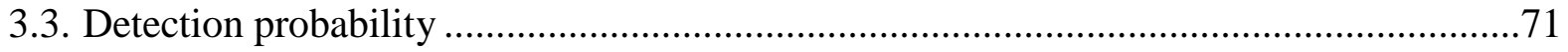

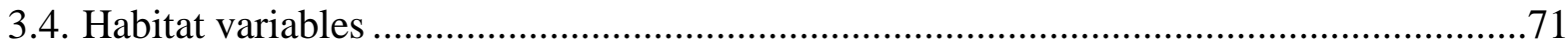

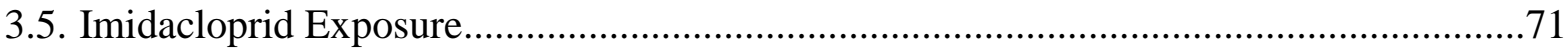

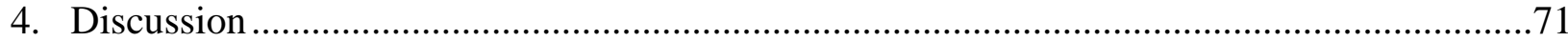

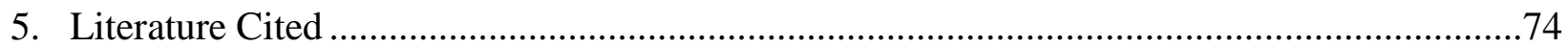




\section{Chapter 4. Benthic Macroinvertebrate Community Responses}

to Imidacloprid Exposure.................................................................................................................................8

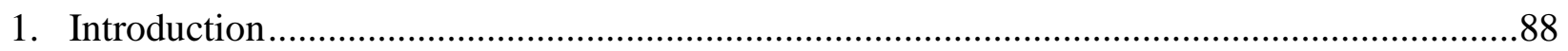

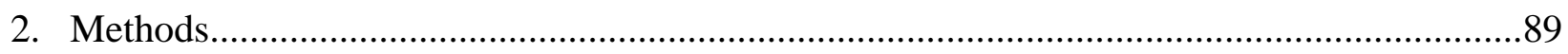

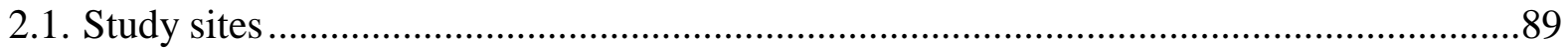

2.2. Water and sediment imidacloprid extraction and quantification ....................................90

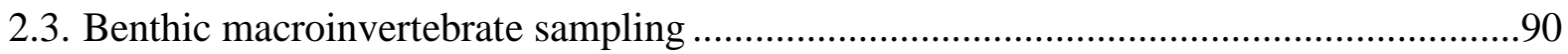

2.4. Benthic macroinvertebrate response metrics .................................................................91

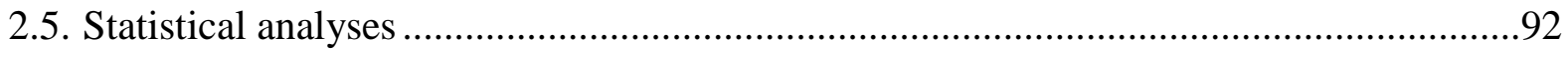

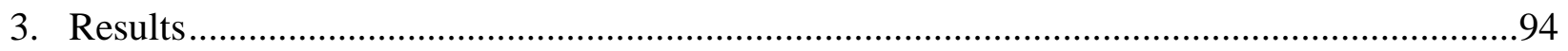

3.1. Water and sediment imidacloprid concentration ........................................................94

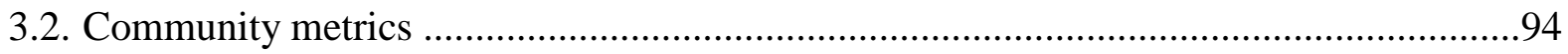

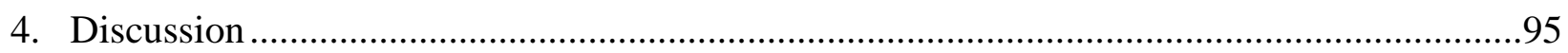

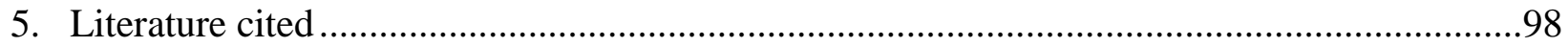




\section{LIST OF TABLES}

\section{Chapter 1.}

Table 1-1. Summary of study sites in New River Gorge National River (NERI), Gauley River National Recreational Area (GARI), and Monongahela National Forest (MNF) in West Virginia, USA, and detection of imidacloprid, imidacloprid-urea, and imidacloprid-olefin in stream water, sediment, invertebrates, and salamanders. We did not detect imidacloprid-urea in water, imidacloprid-urea or imidacloprid-olefin in sediment, imidacloprid-olefin in invertebrates, or imidacloprid-urea in salamanders. NT= not tested.....

\section{Chapter 2.}

Table 2-1. Model selection results for the influence of species (Desmognathus fuscus [northern dusky salamander] and D. monticola [seal salamander]), sex (males, females, and gravid females), and imidacloprid exposure on salamander corticosterone concentration. We sampled 119 salamanders (115 included in the analysis) at Gauley River National Recreational Area (GARI) and New River Gorge National River (NERI) in West Virginia, USA. We tested four predictors of imidacloprid exposure, including whether the site was adjacent to treated trees (Trees), number of applications in adjacent treated stands (Number), whether imidacloprid was detected in the environment (Presence), and concentration in the stream water $(\mathrm{ng} / \mathrm{mL}$; Concentration). We used Akaike's Information Criterion corrected for small sample size (AIC ${ }_{c}$ ) to rank candidate models. The null model is shown as (.) and includes only the intercept. Akaike weights are represented as $w_{i}$

Table 2-2. Model selection results for the influence of species, age (larva or adult/sub-adult), and imidacloprid exposure on salamander body condition index (BCI) score. We standardized BCI scores for each species and thus did not include species as an independent factor in the model selection. Species included Desmognathus fuscus (northern dusky salamander), D. monticola (seal salamander), D. ochrophaeus (Allegheny Mountain dusky salamander), Eurycea spp. (northern and southern two-lined salamanders), and G. porphyriticus (spring salamander). We tested four predictors of imidacloprid exposure, including whether the site was adjacent to treated trees (Trees), number of applications in adjacent treated stands (Number), whether imidacloprid was detected in the environment (Presence), and concentration $(\mathrm{ng} / \mathrm{mL})$ in the stream water (Concentration). We used Akaike's Information Criterion corrected for small sample size $\left(\mathrm{AIC}_{c}\right)$ to rank candidate models. The null model is shown as (.) and includes only the intercept. Akaike weights are represented as $w_{i}$

\section{Chapter 3.}

Table 3-1. Model selection results for detection $(p)$ submodels. Detection predictors tested included relative humidity $(\%)$, number of cover objects flipped, water temperature $\left({ }^{\circ} \mathrm{C}\right.$; linear and quadratic), air temperature $\left({ }^{\circ} \mathrm{C}\right.$; linear and quadratic), and water depth (linear and quadratic). For all species, we also tested one additive model containing the two predictors with the lowest $\mathrm{QAIC}_{c}$. Model selection was based on Quasi Akaike's Information Criterion corrected for small sample size $\left(\mathrm{QAIC}_{c}\right)$. The null model (.) only included the intercept. 
Table 3-2. Model selection results for habitat variables submodels. Habitat predictors tested included water total dissolved solids (TDS; ppm), water $\mathrm{pH}$, hemlock basal area per hectare, total canopy cover $(\%), \%$ of plot covered by boulders or cobble, and benthic macroinvertebrate biomass. We also tested the predictor \% bank leaf cover for D. ochrophaeus. For all species, we also tested one additive model containing the two predictors with the lowest $\mathrm{QAIC}_{c}$. Model selection was based on Quasi Akaike's Information Criterion corrected for small sample size $\left(\mathrm{QAIC}_{c}\right)$. The null model (.) included the most parsimonious detection $(p)$ model.

Table 3-3. Model selection results for imidacloprid predictors. Predictors include imidacloprid concentration in the water ( $\mathrm{ng} / \mathrm{mL}$; Concentration), number of imidacloprid applications (Number), presence of environmental imidacloprid (Presence), presence of treated trees (Trees). Model selection was based on Quasi Akaike's Information Criterion corrected for small sample size $\left(\mathrm{QAIC}_{c}\right)$. The null model included the most parsimonious detection $(p)$ model and the most parsimonious habitat model.

Table 3-4. Parameter estimate $(\beta)$ and standard errors (SE) for imidacloprid predictors. Predictors include imidacloprid concentration in the water $(\mathrm{ng} / \mathrm{mL}$; Concentration), number of imidacloprid applications (Number), presence of environmental imidacloprid (Presence), presence of treated trees (Trees).

\section{Chapter 4.}

Table 4-1. Model selection results for the influence of locality, presence of environmental imidacloprid (Presence), presence of treated trees (Trees), number of imidacloprid applications (Number), and imidacloprid concentration in the water $(\mathrm{ng} / \mathrm{mL}$; Concentration) on benthic macroinvertebrate community metrics. We used Akaike's Information Criterion corrected for small sample size $\left(\mathrm{AIC}_{c}\right)$ to rank candidate models. The null model is shown as (.) and included only the intercept. Akaike weights are represented as $w_{i}$.

Table 4-2. Parameter estimates ( $\beta$ ) and standard errors (SE) for predictor variables for the most parsimonious models (identified in Table 4-2) for each of seven community metrics. 


\section{LIST OF FIGURES}

\section{Chapter 1.}

Figure 1-1. Locations of 48 sampled streams within the Monongahela National Forest, New River Gorge National River, and Gauley River National Recreation Area in West Virginia (inset), USA.

\section{Chapter 2.}

Figure 2-1. Map of study sites to investigate bioaccumulation of imidacloprid and its metabolites in stream salamanders and invertebrates, and sublethal impacts of imidacloprid on salamanders.

West Virginia, USA (insert).

Figure 2-2. Potential sublethal effects of imidacloprid exposure on stream salamanders in West Virginia, USA. (a) Model-estimated relationship between concentration of the hormone corticosterone and total number of imidacloprid applications at the sampling site for male, nongravid female, and gravid female Desmognathus spp. $(\mathrm{n}=115)$. The intercepts represent $D$. fuscus (northern dusky salamander). (b) Model-estimated relationship between salamander body condition index (BCI) score and concentration of imidacloprid in stream water. BCI analyses included 802 individuals representing 5 species. Bars represent model standard errors.

Figure 2-3. Figure 2-3. Boxplot summaries of body condition index (BCI) values used in this study assessing potential sublethal effects of imidacloprid exposure on D. fuscus (DEFU, absent, $\mathrm{n}=54$, present, $\mathrm{n}=153$ ), D. monticola (DEMO, absent, $\mathrm{n}=79$, present, $\mathrm{n}=195), D$. ochrophaeus (DEOC, absent, $\mathrm{n}=43$, present, $\mathrm{n}=98$ ), Eurycea spp. adults (EUSP, absent, $\mathrm{n}=$ 17 , present, $\mathrm{n}=42$ ), and G. porphyriticus (GYPO, absent, $\mathrm{n}=26$, present, $\mathrm{n}=95)$. Mean BCI is indicated with a red circle and generally was lower in streams with imidacloprid present in the environment for each species tested. 45

\section{Chapter 4.}

Figure 4-1. Locations of sampled streams within the Monongahela National Forest, New River Gorge National River, and Gauley River National Recreation Area. West Virginia (inset), USA.103

Figure 4-2. Model-estimated predictions and 95\% confidence intervals (CI) for (a) GLIMPSS, (b) WVSCI, (c) \% Chironomidae + Annelida, (d) \% 5 Dominant Genera, and (e) \% EPT and (f) total biomass. Predictions shown are for sites in the Monongahela National Forest without imidacloprid exposure (MNF-A; $\mathrm{n}=8$ ), Monongahela National Forest with imidacloprid exposure (MNF-P; $\mathrm{n}=16$ ); sites in the National Park Service without imidacloprid exposure (NPS-A; $\mathrm{n}=6$ ); and sites in the National Park Service with imidacloprid exposure (NPS-P; $\mathrm{n}=$ 17).

Figure 4-3. Non-metric multidimensional scaling (NMDS) plot showing differences in functional traits between sites exposed to environmental imidacloprid (present) and not exposed to environmental imidacloprid (absent) in the Monongahela National Forest (a) and two units of NPS in West Virginia (b). The presence and absence groups were not significantly different in 
MNF ( $p=0.93)$ or NPS $(p=0.31)$. Dispersal was significantly different between groups in MNF $(p<0.05)$ but was not different between groups in NPS $(p=0.55)$ 105

Figure 4-4. Non-metric multidimensional scaling (NMDS) plot showing differences in functional traits between sites with treated trees (present) and without treated trees (absent) in the Monongahela National Forest (a) and two units of NPS in West Virginia (b). The presence and absence groups were not significantly different in MNF $(p=0.93)$ or NPS $(p=0.74)$. Dispersal was not significantly different between groups in MNF $(p=0.74)$ or between groups in NPS $(p=$ $0.37)$. 


\section{LIST OF APPENDICES}

\section{Chapter 2.}

Appendix 2-1. Dermal Uptake and Sublethal Effects on Spotted Salamanders (Ambystoma maculatum) from Exposure to Soil Containing High Concentrations of Imidacloprid.....

\section{Chapter 3.}

Appendix 3-1. Salamander sampling subplot layout. Each site had three $3.3 \times 2 \mathrm{~m}$ subplots with $1 \mathrm{~m}$ of the width on the bank and $1 \mathrm{~m}$ of the width in the stream channel.

Appendix 3-2. Summary of means \pm SE for multiple measures of stream habitat for sites without environmental imidacloprid (absent; $\mathrm{n}=14$ ) and with environmental imidacloprid (present; $\mathrm{n}=34$ ). We defined sites as having environmental imidacloprid if imidacloprid or its metabolites were detected in the water or sediment, or if the stream was adjacent to HWA treatments.....

Appendix 3-3. Appendix 3-3. Summary of means \pm SE number of salamanders detected during one survey per site in either the Monongahela National Forest (MNF) or two units of the National Park Service (NPS). Absent = environmental imidacloprid absent; present $=$ environmental imidacloprid present.

\section{Chapter 4.}

Appendix 4-1. Non-metric multidimensional scaling (NMDS) plots of benthic macroinvertebrate genus abundances for each stream site. Abundances differed based on geographic location between the Monongahela National Forest (MNF) and the NPS locations (Gauley River [GARI] and New River Gorge [NERI]). Stress was 0.216. NPS and MNF sites were significantly different $(p=0.002)$....

Appendix 4-2. List of functional traits used to categorize benthic macroinvertebrate taxa for functional traits analysis. Functional traits were assigned to each taxon using Poff et al. (2006), the EPA database (U.S. EPA 2012) when appropriate, or the next most similar known taxa.

Appendix 4-3. Site-level values for imidacloprid and indices of biotic integrity used in analyses.

Site locations are in Table 1-1.

Appendix 4-4. Summary of means \pm SE for seven indicators of benthic macroinvertebrate community integrity for sites without environmental imidacloprid (absent; $n=8$ ) and with environmental imidacloprid (present; $n=16$ ) in the Monongahela National Forest (MNF) and for sites without environmental imidacloprid (absent; $n=6$ ) and with environmental imidacloprid (present; $\mathrm{n}=17$ ) in the National Park Service sites (NPS). 
Appendix 4-5. Scatterplots comparing seven community indices to water imidacloprid concentration $(\mathrm{ng} / \mathrm{mL})$

Appendix 4-6. Scatterplots comparing seven community indices to number of imidacloprid applications for 48 sites sampled on MNF and NPS. 


\section{CHAPTER 1: INTRODUCTION AND LITERATURE REVIEW}

\section{Impact of hemlock woolly adelgid on hemlock forests}

Eastern hemlock (Tsuga canadensis) is a long-lived, late-successional, and ecologically important species that is the predominant species on approximately 931,000 hectares of land in the United States (U.S.; Ellison et al. 2010, McWilliams and Schmidt 2000). Eastern hemlock ranges from as far south as Northern Alabama and Georgia to southern Canada, and reaches its western extent in Wisconsin (Havill et al. 2014). The less common Carolina hemlock ( $T$. caroliniana) is a relict species that exists in several pockets in the Southern U.S. (Havill et al. 2014, Ward et al. 2004). Although hemlocks have low economic value for their timber and pulp, they are recognized for their ecological and aesthetic attributes (Havill et al. 2014). Eastern hemlock is a foundation species in both urban and forested landscapes of the eastern U.S. because it provides critical habitat for diverse plant and animal species (Becker et al. 2008, Ellison 2014, Snyder et al. 2002, Tingley et al. 2002).

In the Appalachian Mountains, hemlocks typically grow near headwater streams and greatly influence stream characteristics such as temperature, nutrient cycling, and the biotic communities within the streams (Ellison et al. 2010, Havill et al. 2014). Hemlock-dominated stands produce deep shade and slowly-decomposing litter, producing damp and cool microclimates (Mathewson 2009). Hemlocks also photosynthesize and store carbon in the spring and fall when deciduous trees are leafless, but fix less carbon and transpire 50\% less water in the summer than deciduous trees, which stabilizes soil moisture levels, stream base-flows, and stream temperatures (Daley et al. 2007, Hadley and Schedlbauer 2002, Snyder et al. 2002). These characteristics enable aquatic macroinvertebrate species that are intolerant of seasonal drying to persist in streams within hemlock forests, resulting in high macroinvertebrate diversity (Snyder et al. 2002). Several macroinvertebrate taxa show strong associations with hemlock forests (Snyder et al. 2002). In addition, streams that drain hemlock forests often have unique communities of birds, salamanders, fish, and macroinvertebrates (Becker et al. 2008, Mathewson 2009, Snyder et al. 2002, Tingley et al. 2002, Ward et al. 2004). Hemlock stands provide the moist conditions that salamanders require for the deposition and development of eggs and for cutaneous respiration (Harper and Guynn 1999, Petranka 1998). 
The most significant threat to eastern hemlock and Carolina hemlock is the non-native insect hemlock woolly adelgid (HWA; Adelges tsugae) (Havill et al. 2014). HWA was first reported in the eastern U.S. in 1951 in Virginia. This population originated from central Japan where the insects feed on southern Japanese hemlocks (T. sieboldii) (Preisser et al. 2014), and was likely introduced to the U.S. on live plant material imported from Japan (Havill et al. 2014). HWA infests hemlock trees in Japan in high numbers without causing substantial injury or tree mortality, likely due to host resistance, host tolerance, and natural enemies of HWA (Havill et al. 2014).

HWA presents an important and immediate threat to eastern hemlock populations and has expanded to ca. $50 \%$ of the eastern hemlock's range (Havill et al. 2014). The threat posed by HWA led the International Union for Conservation of Nature (IUCN) to list eastern hemlock as "Near Threatened" and place it on the Red List of Threatened Species (Farjon 2013). HWA causes hemlock mortality by inducing a systemic hypersensitive response in the hemlock tree which causes localized cell death in the tree and dieback of branches (Havill et al. 2014, Radville et al. 2011). Hemlock mortality occurs more rapidly in the southern U.S. because warmer winter air temperatures can support larger HWA populations (Ellison et al. 2010, Ford et al. 2012). In one study in Connecticut, $80 \%$ of hemlock mortality occurred 15 years after infestation (Small et al. 2005), while in North Carolina, $80 \%$ mortality occurred six years after infestation (Ford et al. 2012). Hemlock generally does not repopulate after HWA-induced death and is instead replaced by hardwood species such as birches (Betula spp.), oaks (Quercus spp.) and maples (Acer spp., Orwig et al. 2002). The loss of hemlock trees throughout the eastern U.S. is expected to cause considerable changes to those ecosystems' functions (Orwig et al. 2008).

\section{Imidacloprid treatment of HWA}

Early treatment of HWA infestations used foliar insecticides, but this approach was replaced in the early 1990s by neonicotinoids because foliar insecticides required frequent reapplication and applications that drenched the foliage (Havill et al. 2014). Neonicotinoids are synthetic derivatives of nicotine which kill insects by acting on their central nervous system and antagonizing the nicotinic acetylcholine receptors (nAChR) (Matsuda et al. 2001, Yamamoto 1999). Neonicotinoids have a greater binding affinity to the $\mathrm{AChR}$ in insect brains than in 
mammalian brains, which makes neonicotinoids more toxic to insects than to mammals (Yamamoto 1999).

There are seven commercially available neonicotinoid compounds (imidacloprid, clothianidin, thiamethoxam, acetamiprid, dinotefuran, thiacloprid, and nitenpyram), of which imidacloprid is the most commonly applied (Elbert et al. 2008). Imidacloprid is a systemic, chloro-nicotinyl insecticide first synthesized in 1985 (Elbert et al. 1998), registered for use in the U.S. in 1994 (Cox 2001), and has become one of the most commonly used insecticides in the world (van Dijk et al. 2013). Imidacloprid is an ingredient in over 400 products and one-fifth of insecticides sold worldwide (Elbert et al. 2008). This pesticide has a wide range of uses, including treating fleas and ticks on domestic animals, controlling termites, and protecting crops from insect pests (Gervais et al. 2010).

Hemlocks are treated with imidacloprid through soil and trunk injections, which control HWA infestations within 1-3 months of application (Havill et al. 2014). Soil injections provide better long-term control of HWA but the risk of leaching imidacloprid from the soil is high. In general, the volume of applied insecticide which reaches its intended target is much smaller than the volume which is released into the environment (Warnhoff and Schneider 1999). Trunk injections reduce the risk of imidacloprid spreading into the surrounding environment, but may only provide protection for HWA for several months (Ward 2004), making re-application necessary for long-term control. Currently, chemical treatments are the most effective method of controlling HWA, although other control options are also being explored, including biological controls such as the predator Laricobius nigrinus (Zilahi-Balogh et al. 2003), silvicultural thinning (Fajvan 2008), and propagating hemlock trees that are putatively resistant to HWA (Caswell et al. 2008).

\section{Leaching of imidacloprid into aquatic systems}

Three previous studies have quantified imidacloprid concentrations in streams associated with HWA treatments. Less than $1.0 \mathrm{ng} / \mathrm{mL}$ of imidacloprid was detected in a stream in Chattahoochee National Forest 720 days after imidacloprid application; no imidacloprid was detected in three other treatment streams (Churchel et al. 2011). Imidacloprid concentrations ranging from $0.053-0.833 \mathrm{ng} / \mathrm{mL}$ were detected in three streams adjacent to HWA treatment areas in Big South Fork National River and Recreational Area during a rain event $(4.7 \mathrm{~cm} / 24$ 
hours) that occurred 184 to 196 days after imidacloprid application, but imidacloprid was not detected in water samples which were collected every month prior to the rain event and for ca. 7 months after the rain event (Wiggins et al. 2018). In the Great Smoky Mountains National Park, water samples were collected 10-100 m downstream of treated areas and 10-100 m upstream of treated areas that each contained 100-1000 hemlock trees treated 1-8 years prior to the study. The samples were analyzed for concentrations of imidacloprid and two of its metabolites (olefin and 5-hydroxy). Imidacloprid was detected in 7 of 10 downstream locations with concentrations ranging from $0.0285-0.3791 \mathrm{ng} / \mathrm{mL}$ but in no upstream locations. All samples were below limit of detection (LOD) for olefin and 5-hydroxy. Concentration of imidacloprid was highly correlated with amount of imidacloprid applied to the treatment area (Benton et al. 2015).

Several characteristics of imidacloprid make it more susceptible to leaching into ground or surface water than many other pesticides. Imidacloprid's high water solubility allows for leaching into groundwater and streams (US EPA 2003). Imidacloprid also has low volatility and a low soil organic water partition coefficient, which is the ratio of the mass of the chemical adsorbed in the soil to the mass of organic carbon in the soil (Ding et al. 2011). These characteristics, in conjunction with the general proximity of hemlock forests to riparian areas, increase the risk of imidacloprid leaching into stream systems (Ding et al. 2011). Imidacloprid is more likely to leach in areas with low organic matter in the soil because it has a high organic binding capacity (Anhalt et al. 2008). Most forests have large quantities of organic matter in the soil, but it is possible that the high doses of imidacloprid applied to the trees saturate the local binding capacity (Anhalt et al. 2008). Imidacloprid in surface water degrades when exposed to sunlight into several photoproducts (Ding et al. 2011), a process known as aqueous photolysis (Colombo et al. 2013), but continual leaching into stream systems may maintain imidacloprid presence in stream systems near treated hemlocks (Benton et al. 2016). Imidacloprid is more likely to leach during rain events (Churchel et al. 2011, Cowles et al. 2009, McGrath et al. 2010). Another route for imidacloprid to enter aquatic systems and negatively impact stream fauna is through the leaves of imidacloprid treated trees falling into streams (Kreutzweiser et al., 2008). Imidacloprid and its metabolites (olefin, 5-hydroxy and dihydroxy) can be detected in hemlock foliage for up to seven years after treatment with a soil drench (Benton et al. 2015). To our knowledge, no studies have directly investigated the persistence of imidacloprid in stream sediment. 


\section{Ecological consequences of imidacloprid treatment on benthic macroinvertebrates}

Several field studies have been conducted to assess whether benthic macroinvertebrates are at risk from HWA treatments. In Great Smoky Mountains National Park, aquatic communities in 9 streams exposed to HWA treatments were compared to upstream reaches without HWA treatment and to pre-treatment data (Benton et al. 2017). Community diversity metrics did not differ between the control and treatment streams or between the pre- and posttreatment data and groups had similar functional feeding groups and life habits (Benton et al. 2017). A study in the Southern Appalachian Mountains surveyed four streams pre- and posttreatment and a reference stream and did not detect differences in community metrics due to imidacloprid exposure (Churchel et al. 2011). These results should be interpreted cautiously because soils at these study sites do not easily leach imidacloprid and imidacloprid was not detected in most study streams (Churchel et al. 2011). An unpublished field study (Devine 2015) conducted in the Monongahela National Forest (MNF) in West Virginia in 2011 compared macroinvertebrates collected upstream and downstream of HWA treatment areas. This study found a weak negative correlation between the amount of imidacloprid applied and the relative abundance of benthic macroinvertebrates. Additionally, this study found that population diversity was significantly lower and there were fewer sensitive taxa in treatment streams (Devine 2015). An additional study conducted in the Netherlands investigated aquatic macroinvertebrate abundances in surface water containing imidacloprid (Van Dijk 2013). Aquatic macroinvertebrate abundance was significantly lower in surface water with higher imidacloprid concentrations for the orders Amphipoda (crustaceans), Diptera (true flies), Ephemeroptera (mayflies), Isopoda (crustaceans) and Basommatophora (snails) (Van Dijk 2013).

Numerous laboratory and microcosm studies have demonstrated negative impacts of imidacloprid on benthic macroinvertebrates. Imidacloprid has been shown to cause substantial mortality at $50 \mu \mathrm{g} / \mathrm{mL}$, and feeding inhibition at $12 \mu \mathrm{g} / \mathrm{mL}$ in stonefly (Pteronarcys dorsata) nymphs and cranefly (Tipula sp.) larvae (Kreutzweiser et al. 2008). Foraging activity was impaired in mayflies at concentrations of $\geq 0.5 \mu \mathrm{g} / \mathrm{mL}$ and immobility in oligochaetes was observed at $5 \mu \mathrm{g} / \mathrm{mL}$ (Alexander et al. 2007). In a microcosm study in which macroinvertebrates were fed imidacloprid-treated maple leaves, macroinvertebrate feeding was inhibited by exposure to imidacloprid concentrations of $1300 \mathrm{mg} / \mathrm{L}$ (Kreutzweiser et al., 2009). Pulses of low 
concentrations of imidacloprid led to decreases in survival and emergence of Ephemeroptera, Tanypodinae, and Orthocladiinae, and an increase in the survival of Radix spp., which is a nonsensitive genus of snail (Columbo et al 2013). This decline occurred despite imidacloprid undergoing aqueous photolysis (Colombo et al. 2013), which is the process in which imidacloprid degrades in sunlight into several photoproducts (Ding et al. 2011). Pulses of imidacloprid treatments in outdoor stream mesocosms to imitate runoff that occurs during rain events caused significant declines in benthic macroinvertebrate abundances and community diversity (Pestana et al. 2009).

Downstream drift of macroinvertebrates is a well-documented reaction to environmental disturbances in which stressors such as toxicants cause invertebrates to become dislodged and move downstream (Beketov and Liess 2008). Imidacloprid triggered downstream drift in a stream microcosm at concentrations which did not cause significant mortality of macroinvertebrates (Beketov and Liess 2008). Interestingly, drift of invertebrates began within only 2 hours of imidacloprid exposure (Beketov and Liess 2008). Similarly, Berghahn et al. (2012) exposed Ephemeroptera larvae, Diptera larvae, and Gammaridae larvae and adults to 3 pulses of imidacloprid in indoor stream mesocosms. The addition of imidacloprid to the mesocosm led to immediate increases in drift in all taxa (Berghahn et al. 2012).

\section{Observed and potential impacts of imidacloprid exposure on amphibians}

North America is a global hotspot for salamander diversity (Yap et al. 2015), and salamanders are particularly abundant in the Appalachian Mountains (Petranka and Murray 2001). One study in the southern Appalachians estimated that salamander density in riparian

habitat was $1.8 / \mathrm{m}^{2}$, which made them the dominant forest predator (Petranka and Murray 2001). However, salamanders, like all amphibian orders, are declining globally. West Virginia has 34 species of salamander, 14 of which are considered to be rare, threatened, or endangered within the state, and 6 of which are considered dependent on headwater streams (WV DNR 2017).

In headwater streams, salamanders are often the dominant vertebrates in terms of abundance and biomass (Burton and Likens 1975, Davic and Welsh 2004). Loss of salamander populations from headwater streams can have ecosystem-wide consequences because salamanders can influence insect population dynamics, regulate detritus food webs, and link stream and terrestrial food webs (Petranka 1998). Thus, salamander occupancy and abundance 
can serve as an indicator of stream quality (Southerland et al. 2004) and ecosystem stress (Lowe and Bolger 2002, Welsh and Ollivier 1998, Wood and Williams 2013).

Although imidacloprid is generally not lethal to adult vertebrates at levels typically found in the environment, studies have found a variety of sublethal impacts to mammals, birds, fish, and frogs, including impacts on reproduction and growth (reviewed by Gibbons et al. 2015). Feng et al. (2004) demonstrated that imidacloprid is genotoxic to the black-spotted pond frog (Pelophylax nigromaculatus) with DNA damage increasing as aquatic concentrations increased. Similarly, imidacloprid exposure led to DNA lesions in Montevideo tree frog (Hypsiboas pulchellus) tadpoles, although this effect was only displayed at concentrations higher than typical field conditions (Pérez-Iglesias et al. 2014). Imidacloprid exposure also decreased survival rates in northern cricket frogs (Acris crepitans) (Ade et al. 2010).

Aquatic salamanders could encounter imidacloprid from ingested invertebrate prey, as well as from direct uptake through their highly permeable skin (Gibbons et al. 2015). Previous studies have not yet evaluated the impact imidacloprid has on wild salamander abundances or whether imidacloprid can have sublethal impacts on salamanders.

\section{Imidacloprid uptake and bioaccumulation}

No previous research has assessed whether salamanders can bio-accumulate imidacloprid, potentially resulting in high concentrations that could have sublethal or lethal effects, and making the chemical available for ingestion by vertebrates that consume salamanders. Several studies have investigated storage and bioaccumulation of imidacloprid in other amphibians. Measurable levels of imidacloprid were detected with liquid chromatography/mass spectrometry (LC/MS) in northern cricket frog, eastern narrowmouth toad (Gastrophryne carolinensis), barking trees frog (Hyla gratiosa), and southern leopard frog (Lithobates sphenocephala) tissues after eight hours of exposure in a laboratory (Glinski et al. 2018, Van Meter et al. 2014, Van Meter et al. 2015).

Several studies have quantified bioaccumulation of imidacloprid in other taxa. The aquatic oligochaete Lumbriculus variegatus is commonly used for evaluating toxicity of freshwater contaminants and was found to biomagnify imidacloprid. Worms exposed to higher concentrations of imidacloprid presented higher levels of imidacloprid in whole body tissues (Sardo and Soares 2010). Imidacloprid concentrations were higher in the liver, gills, gut, and 
muscle of the freshwater fish Australoheros facetus after 48 vs 24 hours of exposure, and imidacloprid was also detected in the blood and brain (Iturburu et al. 2016). A recent study conducted in areas of high-neonicotinoid application in Texas found that $12 \%$ of bobwhite quail had detectable levels of neonicotinoid compounds in the liver, including imidacloprid, acetamiprid, clothianidin, and thiamethoxam (Ertl et al. 2018). All detections were below the limit of quantification, but $20 \%$ of birds displayed tissue degeneration in the liver and testicles (Ertl et al. 2018) which are known secondary targets of neonicotinoids (Yamamoto 1999). However, only one bird with detectable levels of neonicotinoids in the liver also exhibited neonicotinoid-induced tissue damage, suggesting that neonicotinoids may be rapidly metabolized in vivo in birds (Ertl et al. 2018). To our knowledge, no studies have investigated whether benthic macroinvertebrates or crayfish bioaccumulate imidacloprid.

\section{Study Area}

Hemlock trees represent an important natural resource in West Virginia, where they comprise $1 \%$ of forests statewide and are key components to many of the state's tourist attractions (Kish 2007). This study was conducted in the Monongahela National Forest (MNF) and two units of the National Park Service (NPS): Gauley River National Recreational Area (GARI) and New River Gorge National River (NERI) in West Virginia, USA (Figure 1). Hemlock stands in the MNF were treated with a single application of imidacloprid in 2014 or 2015. In NPS units, applications of imidacloprid began in 2006 and re-treatments have occurred annually within the NPS units. Sites in NPS have been treated 1-7 times since 2006 (Table 1-1).

\section{Research goals and summary of chapters}

In aquatic ecosystems, environmental stress typically is first detected at the population level and impacts sensitive species first (Odum 1992). The goal of this research is to use the abundance and diversity of benthic macroinvertebrates and stream salamanders as indicators for the integrity of stream systems. The results of this project will either confirm that the current imidacloprid treatment strategy has minimal non-target impacts, or will inform forest managers that changes in imidacloprid usage may be necessary to minimize environmental impacts. The study will also have broad-scale value, as many agencies use imidacloprid to control a variety of additional insect pests (e.g., emerald ash borer [Agrilus planipennis]; Smitley et al. 2015), and 
because imidacloprid has become a major pesticide for agricultural use (Elbert et al. 2008, Gervais et al. 2010). The specific goals for this thesis are to (1) quantify the concentration of imidacloprid and two of its metabolites (imidacloprid-urea and imidacloprid-olefin) present in stream water and compare these concentrations to hemlock treatment histories; (2) assess the presence/absence of imidacloprid, imidacloprid-urea, and imidacloprid-olefin in stream sediment; (3) compare the concentrations of imidacloprid, imidacloprid-olefin, and imidaclopridurea in stream water with the abundance and health (i.e., body condition) of stream salamanders and community metrics of benthic macroinvertebrate taxa; and (4) investigate whether imidacloprid, imidacloprid-olefin, or imidacloprid-urea are bioaccumulating in stream salamanders and benthic macroinvertebrates.

In the second chapter, I investigate whether stream salamanders and benthic macroinvertebrates bioaccumulate imidacloprid or its metabolites and whether these concentrations are correlated with environmental concentrations of imidacloprid. I also investigate whether imidacloprid exposure and bioaccumulation induce sublethal effects in salamanders, such as changes to the stress hormone corticosterone or body condition.

In the third chapter, I compare the abundances of five stream salamander species to multiple measurements of imidacloprid exposure including the concentration of imidacloprid detected in the water and the presence of environmental imidacloprid.

In the fourth chapter, I compare benthic macroinvertebrate metrics, including Genus Level Index of Most Probably Stream Status (GLIMPSS) and West Virginia Stream Condition Index (WVSCI) to four imidacloprid predictors. I also compare functional traits of benthic macroinvertebrates to the presence of environmental imidacloprid and presence of treated trees.

Eastern hemlocks will continue to decline due to HWA infestation, forcing forest managers to make decisions between the positive impacts of imidacloprid treatment and the effects on non-target species exposed to imidacloprid. The results of this thesis will add to a growing body of literature investigating the influence of HWA treatment and use of neonicotinoid insecticides on non-target species. 


\section{LITERATURE CITED}

Ade, C.M., Boone, M.D., Puglis, H.J. 2010. Effects of an insecticide and potential predators on green frogs and northern cricket frogs. Journal of Herpetology, 44(4): 591-601.

Alexander, A.C., Culp, J.M., Liber, K., Cessna, A.J. 2007. Effects of insecticide exposure on feeding inhibition in mayflies and oligochaetes. Environmental Toxicology and Chemistry, 26(8): 1726-1732.

Anhalt, J.C., Moorman, T.B., Koskinen, W.C. 2008. Degradation and sorption of imidacloprid in dissimilar surface and subsurface soils. Journal of Environmental Science and Health Part B, 43(3): 207-213.

Becker, D.A., Brittingham, M.C., Goguen, C.B. 2008. Effects of hemlock woolly adelgid on breeding birds at Fort Indiantown Gap, Pennsylvania. Northeastern Naturalist, 15(2): $227-240$.

Beketov, M.A., Liess, M. 2008. Potential of 11 pesticides to initiate downstream drift of stream macroinvertebrates. Archives of Environmental Contamination and Toxicology, 55(2): 247-253.

Berghahn, R., Mohr, S., Hübner, V., Schmiediche, R., Schmiedling, I., Svetich-Will, E., Schmidt, R. 2012. Effects of repeated insecticide pulses on macroinvertebrate drift in indoor stream mesocosms. Aquatic Toxicology, 122(2012): 56-66.

Benton, E.P., Grant, J.F., Mueller, T.C., Webster, R.J., Nichols, R.J. 2016. Consequences of imidacloprid treatments for hemlock woolly adelgid on stream water quality in the southern Appalachians. Forest Ecology and Management, 360(2016): 152-158.

Benton, E.P., Grant, J.F., Nichols, R.J., Webster, R.J., Schwartz, J.S., Bailey, J.K. 2017. Risk assessment of imidacloprid use in forest settings on the aquatic macroinvertebrate community. Environmental Toxicology and Chemistry, 36(11): 3108-3119.

Benton, E.P., Grant, J.F., Webster, R.J., Nichols, R.J., Cowles, R.S., Lagalante, A.F., Coots, C.I. 2015. Assessment of imidacloprid and its metabolites in foliage of eastern hemlock multiple years following treatment for hemlock woolly adelgid, Adelges tsugae (Hemiptera: Adelgidae), in forested conditions. Journal of Economic Entomology, 108(6): 2672-2682.

Burton, T.M., Likens, G.E. 1975. Salamander populations and biomass in the Hubbard Brook Experimental Forest, New Hampshire. Copeia, 1975(3): 541-546.

Caswell, T., Casagrande, R., Maynard, B., Preisser, E. 2008. Production and evaluation of eastern hemlocks potentially resistant to the hemlock woolly adelgid, pp. 124-134. In B. Onken and R. Reardon (compilers), Fourth Symposium on Hemlock Woolly Adelgid in the Eastern United States, 12-14 February, 2008.

Churchel, M.A., Hanula, J.L., Berisford, C.W., Vose, J.M., Dalusky, M.J. 2011. Impact of imidacloprid for control of hemlock woolly adelgid on nearby aquatic macroinvertebrate assemblages. Southern Journal of Applied Forestry, 35(1): 26-32. 
Colombo, V., Mohr, S., Berghahn, R., Pettigrove, V. J. 2013. Structural changes in a macrozoobenthos assemblage after imidacloprid pulses in aquatic field-based microcosms. Archives of Environmental Contamination and Toxicology, 65(4): 683-692.

Cowles, R.S. 2009. Optimizing dosage and preventing leaching of imidacloprid for management of hemlock woolly adelgid in forests. Forest Ecology and Management, 257(3): 10261033.

Cox, C. 2001. Insecticide factsheet: imidacloprid. Journal of Pesticide Reform, 21(1):15-21.

Daley, M.J., Phillips, N.G., Pettijohn, C., Hadley, J.L. 2007. Water use by eastern hemlock (Tsuga canadensis) and black birch (Betula lenta): implications of effects of the hemlock woolly adelgid. Canadian Journal of Forest Research, 37(10): 2031-2040.

Davic, R.D., Welsh, H.H. 2004. On the ecological roles of salamanders. Annual Review of Ecology, Evolution, and Systematics, 35(2004): 405-434.

Devine, H. 2015. Long-term effects of hemlock imidacloprid treatments on stream macroinvertebrate assemblages. Unpublished study.

Ding, T., Jacobs, D., Lavine, B.K. 2011. Liquid chromatography-mass spectrometry identification of imidacloprid photolysis products. Microchemical Journal, 99(2): 535541.

Elbert, A., Haas, M., Springer, B., Thielert, W., Nauen, R. 2008. Mini review: applied aspects of neonicotinoid uses in crop protection. Pest Management Science, 64:1099-1105.

Elbert, A., Nauen, R., Leicht, W. 1998. Imidacloprid, a novel chloronicotinyl insecticide: biological activity and agricultural importance. In Insecticides with novel modes of action (pp. 50-73). Springer, Berlin, Heidelberg.

Ellison, A.M. 2014. Experiments are revealing a foundation species: a case study of eastern hemlock (Tsuga canadensis). Advances in Ecology, 2014: article 456904.

Ellison, A.M., Barker-Plotkin, A.A., Foster, D.R., Orwig, D.A. 2010. Experimentally testing the role of foundation species in forests: the Harvard Forest Hemlock Removal Experiment. Methods in Ecology and Evolution, 1(2): 168-179.

Ertl, H.M., Mora, M.A., Boellstorff, D.E., Brightsmith, D., Carson, K. 2018. Potential effects of neonicotinoid insecticides on northern bobwhites. Wildlife Society Bulletin, 42(4): 649655.

Feng, S., Kong, Z., Wang, X., Zhao, L., Peng, P. 2004. Acute toxicity and genotoxicity of two novel pesticides on amphibian, Rana $N$ Hallowell. Chemosphere. 56(5): 457-463.

Ford, C.R., Elliott, K.J., Clinton, B.D., Kloeppel, B.D., Vose, J.M. 2012. Forest dynamics following eastern hemlock mortality in the southern Appalachians. Oikos, 121(4): 523536.

Gervais, J.A., Luukinen, B., Buhl, K., Stone, D. 2010. Imidacloprid technical fact sheet. National Pesticide Information Center, Oregon State University Extension Services. https://web.archive.org/web/20190706153910/http://npic.orst.edu/factsheets/arc hive/imidacloprid.html . Downloaded on 10 July 2017. 
Gibbons, D., Morrissey, C., Mineau, P. 2015. A review of the direct and indirect effects of neonicotinoids and fipronil on vertebrate wildlife. Environmental Science and Pollution Research, 22(1): 103-118.

Glinski, D.A., Henderson, W.M., Van Meter, R.J., Purucker, S.T. 2018. Effect of hydration status on pesticide uptake in anurans following exposure to contaminated soils. Environmental Science and Pollution Research, 2018: 1-10.

Hadley, J.L., Schedlbauer, J.L. 2002. Carbon exchange of an old-growth eastern hemlock (Tsuga canadensis) forest in central New England. Tree Physiology, 22(15-16): 1079-1092.

Harper, C.A., Guynn Jr, D.C. 1999. Factors affecting salamander density and distribution within four forest types in the Southern Appalachian Mountains. Forest Ecology and Management, 114(2-3): 245-252.

Havill, N.P., Vieira, L.C., Salom, S.M. 2014. Biology and control of hemlock woolly adelgid. USDA Forest Service, Forest Health Technology Enterprise Team, Morgantown, West Virginia.

Iturburu, F.G., Zömisch, M., Panzeri, A.M., Crupkin, A.C., Contardo-Jara, V., Pflugmacher, S., Menone, M.L. 2017. Uptake, distribution in different tissues, and genotoxicity of imidacloprid in the freshwater fish Australoheros facetus. Environmental toxicology and chemistry, 36(3): 699-708.

Fajvan, M.A., 2008. The role of silvicultural thinning in eastern forests threatened by hemlock woolly adelgid (Adelges tsugae). In: Deal, R.L. (Tech. Ed.), Integrated restoration of forested ecosystems to achieve multiresource benefits: proceedings of the 2007 national silviculture workshop, Gen. Tech. Rep. PNW733, USDA, Forest Service, Pacific Northwest Research Station, pp. 247-256.

Farjon, A. 2013. Tsuga canadensis. The IUCN Red List of Threatened Species 2013: e.T42431A2979676. https://web.archive.org/web/20190706154026/https://www.iucnredli st.org/species/42431/2979676. Downloaded on 08 April 2017.

Kish, K. 2007. Hemlock Woolly Adelgid Management Plan. West Virginia Department of Agriculture Cooperative Forest Health Protection Plan.

Kreutzweiser, D.P., Thompson, D.G., Scarr, T.A. 2009. Imidacloprid in leaves from systemically treated trees may inhibit litter breakdown by non-target invertebrates. Ecotoxicology and Environmental Safety, 72(4): 1053-1057.

Kreutzweiser, D.P., Good, K.P., Chartrand, D.T., Scarr, T.A., Thompson, D.G. 2008. Toxicity of the systemic insecticide, imidacloprid, to forest stream insects and microbial communities. Bulletin of Environmental Contamination and Toxicology, 80(3): 211-214.

Lowe, W.H., Bolger, D.T. 2002. Local and landscape-scale predictors of salamander abundance in New Hampshire headwater streams. Conservation Biology, 16(1): 183-193.

Matsuda, K., Buckingham, S.D., Kleier, D., Rauh, J.J., Grauso, M., Sattelle, D.B. 2001. Neonicotinoids: insecticides acting on insect nicotinic acetylcholine receptors. Trends in Pharmacological Sciences, 22(11): 573-580. 
Mathewson, B. 2009. The relative abundance of eastern red-backed salamanders in eastern hemlock-dominated and mixed deciduous forests at Harvard Forest. Northeastern Naturalist, 16(1): 1-12.

McGrath, G., Hinz, C., Sivapalan, M. 2010. Assessing the impact of regional rainfall variability on rapid pesticide leaching potential. Journal of contaminant hydrology, 113(1-4): $56-65$.

McWilliams, W.H., Schmidt, T.L. 2000. Composition, structure, and sustainability of hemlock ecosystems in Eastern North America. In: McManus, K.; Shields, K.; Souto, D., eds. Proceedings, Symposium on sustainable management of hemlock ecosystems in Eastern North America; 1999 June 22-24; Durham, NH. Gen. Tech. Rep. NE-267. Newtown Square, PA: U.S. Department of Agriculture, Forest Service, Northeastern Research Station; 5-10.

Odum, E.P. 1992. Great ideas in ecology for the 1990s. BioScience, 42(7): 542-545.

Orwig, D.A., Foster, D.R., Mausel, D.L. 2002. Landscape patterns of hemlock decline in New England due to the introduced hemlock woolly adelgid. Journal of Biogeography, 29(10-11): 1475-1487.

Orwig, D.A., Cobb, R.C., D’Amato, A.W., Kizlinski, M.L., Foster, D.R. 2008. Multi-year ecosystem response to hemlock woolly adelgid infestation in southern New England forests. Canadian Journal of Forest Research, 38(4): 834-843.

Pérez-Iglesias, J.M., de Arcaute, C.R., Nikoloff, N., Dury, L., Soloneski, S., Natale, G.S., Larramendy, M.L. 2014. The genotoxic effects of the imidacloprid-based insecticide formulation Glacoxan Imida on Montevideo tree frog Hypsiboas pulchellus tadpoles (Anura, Hylidae). Ecotoxicology and Environmental Safety, 104(2014): 120-126.

Pestana, J.L.T., Alexander, A.C., Culp, J.M., Baird, D.J., Cessna, A.J., Soares, A.M.V.M. 2009. Structural and functional responses of benthic invertebrates to imidacloprid in outdoor stream mesocosms. Environmental Pollution, 157(8): 2328-2334.

Petranka, J.W. 1998. Salamanders of the United States and Canada. Smithsonian Institute Press, Washington, D.C., USA.

Petranka, J.W., Murray, S.S. 2001. Effectiveness of removal sampling for determining salamander density and biomass: a case study in an Appalachian streamside community. Journal of Herpetology, 35(1): 36-44.

Preisser, E.L, Oten, K.L.F., Hain, F.P. 2014. Hemlock woolly adelgid in the eastern United States: what have we learned? Southeastern Naturalist, 13(6): 1-15

Radville, L., Chaves, A., Preisser, E.L. 2011. Variation in plant defense against invasive herbivores: evidence for a hypersensitive response in eastern hemlocks (Tsuga canadensis). Journal of Chemical Ecology, 37(6): 592-597.

Sardo, A.M., Soares, A.M.V.M. 2010. Assessment of the effects of the pesticide imidacloprid on the behaviour of the aquatic oligochaete Lumbriculus variegatus. Archives of environmental contamination and toxicology, 58(3): 648-656. 
Small, M.J., Small, C.J., Dreyer, G.D. 2005. Changes in a hemlock-dominated forest following woolly adelgid infestation in southern New England. The Journal of the Torrey Botanical Society, 132(3):458-470.

Smitley, D.R., Herms, D.A., Davis, T.W. 2015. Efficacy of soil-applied neonicotinoid insecticides for long-term protection against emerald ash borer (Coleoptera: Buprestidae). Journal of Economic Entomology, 108(2015): 2344-2353.

Snyder, C.D., Young, J.A., Lemarié, D.P., Smith, D.R. 2002. Influence of eastern hemlock (Tsuga canadensis) forests on aquatic invertebrate assemblages in headwater streams. Canadian Journal of Fisheries and Aquatic Sciences, 59(2): 262-275.

Southerland, M.T., Jung, R.E., Baxter, D.P., Chellman, I.C. Mercurio, G., Vølstad, J.H. 2004. Stream salamanders as indicators of stream quality in Maryland, USA. Applied Herpetology, 2(1): 23-46.

Tingley, M.W., Orwig, D.A., Field, R., Motzkin, G. 2002. Avian response to removal of a forest dominant: consequences of hemlock woolly adelgid infestations. Journal of Biogeography, 29(10-11): 1505-1516.

U.S. Environmental Protection Agency. 2003. Imidacloprid; pesticide tolerances. Fed. Regist. 68, 35303-35315 [online]. http://www.epa.gov/fedrgstr/EPA-PEST/ 2003/June/Day13/p14880.htm. U.S. EPA, Washington, DC.

Van Dijk, T.C., Van Staalduinen, M.A., Van der Sluijs, J.P. 2013. Macro-invertebrate decline in surface water polluted with imidacloprid. PLoS ONE, 8(5): e62374.

Van Meter, R.J., Glinski, D.A., Henderson, W.M., Garrison, A.W., Cyterski, M., Purucker, S.T. 2015. Pesticide uptake across the amphibian dermis through soil and overspray exposures. Archives of Environmental Contamination and Toxicology, 69(4): 545-556.

Van Meter, R.J., Glinski, D.A., Hong, T., Cyterski, M., Henderson, W.M., Purucker, S.T. 2014. Estimating terrestrial amphibian pesticide body burden through dermal exposure. Environmental pollution, 193(2013): 262-268.

Ward, J.S., Montgomery, M.E., Cheah, C.A.J., Onken, B.P., Cowles, R.S. 2004. Eastern hemlock forests: guidelines to minimize the impacts of hemlock woolly adelgid. USDA Forest Service.

Wamhoff, H., Schneider, V. 1999. Photodegradation of imidacloprid. Journal of Agricultural and Food Chemistry, 47(4): 1730-1734.

Welsh, Jr., H.H., Ollivier, L.M. 1998. Stream amphibians as indicators of ecosystem stress: a case study from California's redwoods. Ecological Applications, 8(4): 1118-1132.

Wiggins, G., Benton, E., Grant, J., Kerr, M., Lambdin, P. 2018. Short-term detection of imidacloprid in streams after applications in forests. Journal of Environmental Quality, 47(3): 571-578.

Wood, P.B., Williams, J.M. 2013. Impact of valley fills on streamside salamanders in southern West Virginia. Journal of Herpetology, 47(1): 119-125.

Welsh, Jr., H.H., Ollivier, L.M. 1998. Stream amphibians as indicators of ecosystem stress: a case study from California's redwoods. Ecological Applications, 8(4): 1118-1132. 
West Virginia DNR. "Rare, Threatened, and Endangered Species in West Virginia." Web. Accessed 11 July 2017. Available from https://web.archive.org/web/20190706154431/http://www.wvdnr.gov/Wildlife/PDFFiles/ RTE_Animals.pdf.

Yamamoto I, Casida JE, eds. 1999. Nicotinoid insecticides and the Nicotinic Acetylcholine Receptor. SpringerVerlag, Tokyo, Japan.

Yap, T.A., Koo, M.S., Ambrose, R.F., Wake, D.B., Vredenburg, V.T. 2015. Averting a North American biodiversity crisis. Science, 349(6247): 481-482.

Zilahi-Balogh, G.M.G., Salom, S.M., Kok, L.T. 2003. Development and reproductive biology of Laricobius nigrinus, a potential biological control agent of Adelges tsugae. Biocontrol, 48(3): 293-306. 

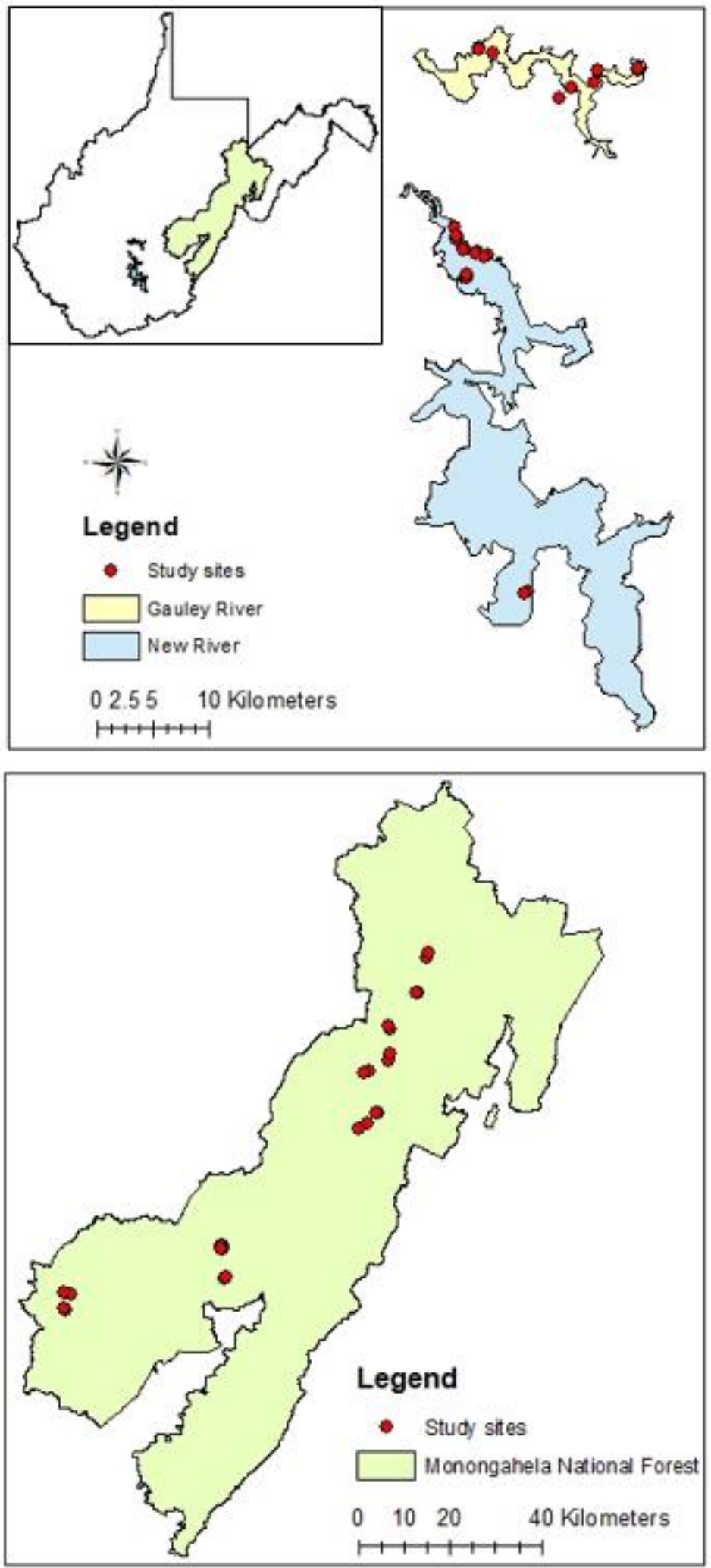

Figure 1-1. Locations of 48 sampled streams within the Monongahela National Forest, New River Gorge National River, and Gauley River National Recreation Area in West Virginia (inset), USA. 
Table 1-1. Summary of study sites in New River Gorge National River (NERI), Gauley River National Recreational Area (GARI), and Monongahela National Forest (MNF) in West Virginia, USA, and detection of imidacloprid, imidacloprid-urea, and imidaclopridolefin in stream water, sediment, invertebrates, and salamanders. We did not detect imidacloprid-urea in water, imidacloprid-urea or imidacloprid-olefin in sediment, imidacloprid-olefin in invertebrates, or imidacloprid-urea in salamanders. NT $=$ not tested.

\begin{tabular}{|c|c|c|c|c|c|c|c|c|c|c|c|c|}
\hline Site & Locality & Latitude & Longitude & $\begin{array}{l}\# \\
\text { Imidacloprid } \\
\text { Applications }\end{array}$ & $\begin{array}{l}\text { \# Years } \\
\text { Treated }\end{array}$ & $\begin{array}{r}\text { Imidacloprid } \\
\text { in water } \\
(\mathrm{ng} / \mathrm{mL})\end{array}$ & $\begin{array}{r}\text { Imidacloprid- } \\
\text { olefin in } \\
\text { water } \\
(\mathrm{ng} / \mathrm{mL})\end{array}$ & $\begin{array}{r}\text { Imidacloprid } \\
\text { in sediment }\end{array}$ & $\begin{array}{r}\text { Imidacloprid } \\
\text { in } \\
\text { invertebrates } \\
(\mathrm{ng} / \mathrm{mL})\end{array}$ & $\begin{array}{r}\text { Imidacloprid- } \\
\text { urea in } \\
\text { invertebrates } \\
(\mathrm{ng} / \mathrm{mL})\end{array}$ & $\begin{array}{r}\text { Mean } \\
\text { Imidacloprid } \\
\text { in } \\
\text { salamanders } \\
(\mathrm{ng} / \mathrm{mL}) \\
\end{array}$ & $\begin{array}{r}\text { Mean } \\
\text { Imidacloprid- } \\
\text { olefin in } \\
\text { salamanders } \\
(\mathrm{ng} / \mathrm{mL}) \\
\end{array}$ \\
\hline 1 & NERI & 38.0724 & -81.07799 & 0 & 0 & 0 & NT & absent & NT & NT & NT & NT \\
\hline 2 & NERI & 38.0757 & -81.07781 & 149 & 3 & 11.28 & NT & absent & 35.67 & 34.72 & 0 & 11.61 \\
\hline 3 & NERI & 38.0829 & -81.07841 & 17 & 1 & 0 & NT & absent & NT & NT & 0 & 4.94 \\
\hline 4 & NERI & 38.0757 & -81.07781 & 138 & 2 & 121.43 & NT & present & 31.64 & 41.89 & 31.8 & 9.47 \\
\hline 5 & GARI & 38.2108 & -80.93223 & 0 & 0 & 0 & NT & absent & NT & NT & NT & NT \\
\hline 6 & GARI & 38.2007 & -80.93565 & 214 & 3 & 17.38 & NT & absent & 14.66 & 50.81 & 22.57 & 6.7 \\
\hline 7 & MNF & 38.3318 & -80.12669 & 5 & 1 & 20.21 & 0 & absent & NT & NT & NT & NT \\
\hline 8 & MNF & 38.3325 & -80.12062 & 66 & 1 & 0 & 0 & absent & NT & NT & NT & NT \\
\hline 9 & GARI & 38.1885 & -80.97104 & 0 & 0 & 0 & NT & present & NT & NT & 15.97 & 8.26 \\
\hline 10 & GARI & 38.1968 & -80.95945 & 494 & 3 & 61.54 & NT & present & NT & NT & 21.5 & 7.38 \\
\hline 11 & NERI & 38.0673 & -81.07002 & 0 & 0 & 0 & NT & absent & NT & NT & 6.36 & 6.32 \\
\hline 12 & NERI & 38.065 & -81.07016 & 76 & 1 & 12.79 & NT & absent & 25.17 & 57.74 & NT & NT \\
\hline 13 & NERI & 38.0633 & -81.05567 & 0 & 0 & 0 & NT & absent & NT & NT & NT & NT \\
\hline 14 & NERI & 38.0622 & -81.05681 & 3993 & 7 & 0 & NT & absent & 23.82 & 34.2 & NT & NT \\
\hline 15 & GARI & 38.2286 & -81.05421 & 0 & 0 & 0 & NT & absent & NT & NT & NT & NT \\
\hline 16 & GARI & 38.227 & -81.05398 & 23 & 1 & 6.52 & NT & absent & NT & NT & 0 & 9.45 \\
\hline 17 & MNF & 38.3003 & -80.51005 & 0 & 0 & 0 & 0 & absent & NT & NT & NT & NT \\
\hline
\end{tabular}




\begin{tabular}{|c|c|c|c|c|}
\hline 18 & MNF & 38.3057 & -80.52673 & 52 \\
\hline 19 & MNF & 38.7583 & -79.70806 & 5 \\
\hline 20 & MNF & 38.7698 & -79.70422 & 60 \\
\hline 21 & MNF & 38.8196 & -79.70385 & 0 \\
\hline 22 & MNF & 38.8245 & -79.70469 & 60 \\
\hline 23 & MNF & 38.3943 & -80.13086 & 0 \\
\hline 24 & MNF & 38.3889 & -80.13067 & 120 \\
\hline 25 & MNF & 38.3946 & -80.13295 & 0 \\
\hline 26 & MNF & 38.3883 & -80.13607 & 82 \\
\hline 27 & MNF & 38.8895 & -79.62868 & 0 \\
\hline 28 & MNF & 38.8893 & -79.63266 & 60 \\
\hline 29 & NERI & 38.0417 & -81.06611 & 0 \\
\hline 30 & NERI & 38.0443 & -81.06623 & 169 \\
\hline 31 & GARI & 38.2239 & -81.03972 & 0 \\
\hline 32 & GARI & 38.2247 & -81.04007 & 675 \\
\hline 33 & MNF & 38.2706 & -80.52364 & 0 \\
\hline 34 & MNF & 38.2749 & -80.52707 & 34 \\
\hline 35 & MNF & 38.6536 & -79.73735 & 0 \\
\hline 36 & MNF & 38.6331 & -79.75985 & 56 \\
\hline 37 & MNF & 38.6533 & -79.73853 & 0 \\
\hline 38 & MNF & 38.6237 & -79.78591 & 47 \\
\hline 39 & NERI & 38.0598 & -81.04568 & 0 \\
\hline
\end{tabular}

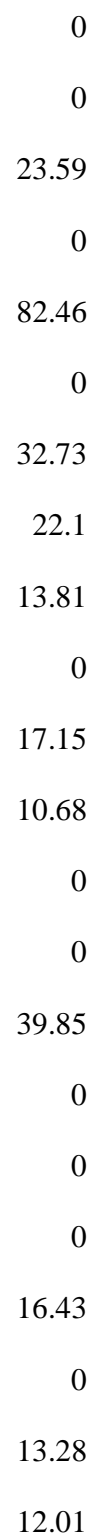

\begin{tabular}{|c|c|c|c|c|c|}
\hline 0 & absent & 35.55 & 119.35 & NT & NT \\
\hline 0 & absent & NT & NT & NT & NT \\
\hline 40.67 & absent & 25.69 & 146.93 & NT & NT \\
\hline 0 & absent & NT & NT & NT & NT \\
\hline 0 & present & 68.38 & 19.96 & NT & NT \\
\hline 0 & absent & NT & NT & NT & NT \\
\hline 0 & absent & 14.05 & 81.66 & NT & NT \\
\hline 0 & absent & NT & NT & NT & NT \\
\hline 0 & absent & 15.7 & 201.44 & NT & NT \\
\hline 0 & present & NT & NT & NT & NT \\
\hline 0 & absent & 38.51 & 77.6 & NT & NT \\
\hline NT & absent & NT & NT & NT & NT \\
\hline NT & absent & NT & NT & NT & NT \\
\hline NT & absent & NT & NT & 0 & 10.97 \\
\hline NT & absent & 22.17 & 78.92 & 33.81 & 7.22 \\
\hline 0 & absent & NT & NT & NT & NT \\
\hline 0 & absent & 18.87 & 179.27 & NT & NT \\
\hline 0 & absent & NT & NT & NT & NT \\
\hline 0 & absent & NT & NT & NT & NT \\
\hline 0 & absent & NT & NT & NT & NT \\
\hline 0 & absent & 13.5 & 0 & NT & NT \\
\hline NT & absent & NT & NT & NT & NT \\
\hline
\end{tabular}




\begin{tabular}{|c|c|c|c|c|c|c|c|c|c|c|c|c|}
\hline 40 & NERI & 38.0591 & -81.04772 & 42 & 2 & 15.68 & NT & absent & 12.05 & 123.6 & NT & NT \\
\hline 41 & NERI & 37.7862 & -81.00425 & 0 & 0 & 10.93 & NT & present & NT & NT & NT & NT \\
\hline 42 & NERI & 37.7854 & -81.00735 & 762 & 2 & 20.31 & NT & absent & NT & NT & NT & NT \\
\hline 43 & GARI & 38.2109 & -80.89195 & 0 & 0 & 8.12 & NT & absent & NT & NT & NT & NT \\
\hline 44 & GARI & 38.2113 & -80.8906 & 237 & 2 & 489.55 & NT & present & NT & NT & NT & NT \\
\hline 45 & MNF & 38.9606 & -79.60808 & 0 & 0 & 0 & 0 & absent & NT & NT & NT & NT \\
\hline 46 & MNF & 38.9685 & -79.60256 & 60 & 1 & 0 & 0 & absent & NT & NT & NT & NT \\
\hline 47 & $\mathrm{MNF}$ & 38.7381 & -79.75739 & 0 & 0 & 0 & 0 & absent & NT & NT & NT & NT \\
\hline 48 & MNF & 38.7318 & -7.76892 & 120 & 1 & 116.04 & 5.11 & present & NT & NT & NT & NT \\
\hline
\end{tabular}




\title{
CHAPTER 2: BIOACCUMULATION OF THE PESTICIDE IMIDACLOPRID IN STREAM ORGANISMS AND SUBLETHAL EFFECTS ON SALAMANDERS
}

\begin{abstract}
The insecticide imidacloprid is widely used to mitigate hemlock (Tsuga spp.) mortality resulting from the invasive hemlock woolly adelgid (HWA; Adelges tsugae), but evidence suggests that imidacloprid can have negative impacts on adjacent stream systems. Laboratory studies have shown that imidacloprid bioaccumulates in anurans and spotted salamanders and causes sublethal effects, but no studies have investigated whether salamanders or invertebrates in streams adjacent to HWA treatments can bioaccumulate imidacloprid. We collected Desmognathus spp. from seven streams directly adjacent to HWA treatments and four streams not adjacent to HWA treatments in West Virginia. We also collected benthic invertebrates from 15 streams adjacent to HWA treatments. We assessed the effect of imidacloprid exposure and imidacloprid bioaccumulation on levels of the stress hormone, corticosterone, and body condition indices (BCI). Of 107 tested salamanders, we detected imidacloprid bioaccumulation in the tissues of 14 Desmognathus spp. and the metabolite imidacloprid-olefin in the tissues of 19 Desmognathus spp. for a total of 29 individuals with one or both chemicals. Of 15 tested benthic invertebrate samples, we detected imidacloprid bioaccumulation in 15 samples and imidaclopridurea in 13 samples. The top model for corticosterone included additive effects of species, sex, and number of imidacloprid applications in adjacent treated stands, and corticosterone levels increased with an increasing number of imidacloprid applications adjacent to the stream. The top model for BCI contained concentration of imidacloprid in stream water as a predictor, and BCI decreased with increasing imidacloprid concentration. This study provides strong evidence that salamanders and stream invertebrates bioaccumulate imidacloprid which leaches from HWA treatments and that imidacloprid is associated with sublethal effects in salamanders.
\end{abstract}

\section{INTRODUCTION}

Eastern hemlock (Tsuga canadensis) and Carolina hemlock (T. caroliniana) are ecologically important tree species in eastern North America that provide unique microhabitat conditions used by diverse invertebrate and vertebrate taxa (Becker et al. 2008, Ellison 2014, Snyder et al. 2002, Tingley et al. 2002). Hemlock trees exert a strong influence on the abiotic environment by creating deep shade that reduces ground and stream temperatures, and by 
producing litter with a slow rate of decomposition, which stabilizes soil moisture levels (Daley et al. 2007, Hadley and Schedlbauer 2002, Mathewson 2009, Snyder et al. 2002). Hemlock populations are currently being impacted by the non-native insect hemlock woolly adelgid (HWA; Adelges tsugae), which has spread to ca. 50\% of the geographic distribution of Eastern hemlock (Havill et al. 2014). In response to substantial mortality observed in infested hemlock stands (e.g., Krapfl et al. 2011), HWA control programs have been widely implemented on public lands in the United States (Vose et al. 2013). The most common and effective method of preventing HWA-induced tree death is application of the neonicotinic insecticide imidacloprid (Webb et al. 2003). Although neonicotinoids are highly selective for insect nicotinic acetylcholine receptors (nAChR), many studies have documented effects to health and survival of vertebrates exposed to this class of insecticides (Gibbons et al. 2015, Hallman et al. 2014, Matsuda et al. 2001, Yamamoto 1999). Imidacloprid is generally not lethal to adult vertebrates at concentrations typically found in the environment, but studies have found a variety of sublethal effects to mammals, birds, fish, and frogs, including effects on reproduction and growth (reviewed by Gibbons et al. 2015).

North America is a global hotspot for salamander diversity (Yap et al. 2015), particularly the Appalachian Mountains in the eastern United States (Petranka and Murray 2001). In headwater streams, salamanders are often the dominant vertebrates in terms of abundance and biomass (Burton and Likens 1975, Davic and Welsh 2004). Several studies have shown that imidacloprid can leach from HWA treatments into adjacent streams (Benton et al. 2017, Churchel et al. 2011, Wiggins et al. 2018), thus potentially exposing stream salamanders to the insecticide. Research investigating the physiological and ecological consequences of imidacloprid on salamanders is lacking, but in anurans, exposure to imidacloprid can cause DNA damage and increased mortality rates (Ade et al. 2010, Feng et al. 2004, Pérez-Iglesias et al. 2014). Additionally, laboratory studies have documented sublethal and lethal effects of imidacloprid exposure on benthic macroinvertebrates (Alexander et al. 2007, Columbo et al. 2013, Kreutzweiser et al. 2008, Kreutzweiser et al. 2009), which are a major food resource for stream salamanders (Petranka 1998).

One potential result of exposure to imidacloprid is bioaccumulation of the pesticide. In a concurrent study, we found that terrestrial spotted salamanders (Ambystoma maculatum) are capable of uptaking imidacloprid dermally through exposure to contaminated soil, and that 
exposure time and concentration were associated with reduced body condition and prey consumption (Appendix 2-1). Measurable levels of imidacloprid were detected in northern cricket frog (Acris crepitans), eastern narrowmouth toad (Gastrophryne carolinensis), barking tree frog (Hyla gratiosa), and southern leopard frog (Lithobates sphenocephala) tissues after 8 hours of exposure to imidacloprid in a laboratory (Glinski et al. 2018, Van Meter et al. 2014, Van Meter et al. 2015). To our knowledge, no studies have investigated whether HWA control programs are resulting in imidacloprid bioaccumulation in stream salamanders. Additionally, stream salamanders prey on crayfish and benthic macroinvertebrates (reviewed by Petranka 1998), and thus bioaccumulation of imidacloprid in stream invertebrates is a potential route of pesticide exposure for salamanders and other vertebrates.

Sublethal effects of environmental stressors have been associated with hormone level changes in amphibians, particularly the hormone corticosterone. Corticosterone is a glucocorticoid hormone produced by the hypothalamus-pituitary-interrenal (HPI) axis that is associated with reproduction, development, growth, and stress in amphibians (Romero et al. 2004). Corticosterone enables an animal to maintain allostasis when exposed to a stressor by increasing available energy or causing behavioral changes (McEwen and Wingfield 2003). Longterm elevation of corticosterone levels induced by chronic stressors can have negative effects, including suppression of the immune system and growth (Romero et al. 2004). Multiple studies have documented increases in corticosterone levels in salamanders due to environmental stressors such as competition for habitat (Cooperman et al. 2004), increased temperature (Novarro et al. 2018), low moisture (Charbonnier et al. 2018), higher acidity (Chambers et al. 2013), and vernal pool size (Millikin et al. 2019). Similar associations were found in anurans where corticosterone was elevated in environments with limited food (Glennemeier and Denver 2002), higher anthropogenic disturbance like traffic noise (Troïanowski et al 2017), and presence of environmental contaminants (Hopkins et al. 1997).

In addition to influencing hormone levels, exposure to contaminants can negatively impact the size, growth rate, and body condition of individuals. For example, exposure to the herbicide atrazine was associated with smaller sizes and lower weights in Tiger Salamander (Ambystoma tigrinum) larvae (Larson et al. 1998), reduced Cuban tree frog (Osteopilus septentrionalis) tadpole snout-vent length (SVL) and mass (Gabor et al. 2018), and decreased growth rate in Southern Leopard Frogs (Lithobates sphenocephala; Adelizzi 2019). Negative 
effects on the health of individuals can ultimately result in population-level declines if they affect growth, reproduction, or survival rates (Hayes et al. 2010, Willson et al. 2012).

The purpose of this study was to determine if salamanders inhabiting streams adjacent to HWA treatments are bioaccumulating imidacloprid, and if there are detectable sublethal effects on individuals. In addition, we assessed bioaccumulation of imidacloprid and its metabolites in benthic macroinvertebrates at a subset of the study sites. We used corticosterone levels and body condition indices (BCI) to assess sublethal effects and tested whether they are correlated with imidacloprid concentration in salamander tissues and stream water at the time of sampling. We hypothesized that salamanders in streams with imidacloprid would have the chemical in their body, and that salamander imidacloprid concentration would be positively correlated with environmental concentration. We also hypothesized that salamanders with higher levels of imidacloprid in their tissues and salamanders collected from streams with higher imidacloprid concentrations would have higher levels of corticosterone and lower BCI scores, indicative of sublethal effects from imidacloprid exposure.

\section{METHODS}

\subsection{Study Sites}

This study was conducted in the Monongahela National Forest (MNF) and two units of the National Park Service (NPS): Gauley River National Recreational Area (GARI) and New River Gorge National River (NERI) in West Virginia, USA (Fig. 2-1). Hemlock stands in the MNF were treated with a single application of imidacloprid in 2014 or 2015. Hemlock stand treatments in NPS units began in 2006 and have continued annually, including repeated applications at 10 of the sampling locations. We did not select NPS treatment sites if the last treatment occurred prior to 2011. We used ArcGIS 10.4 to identify candidate streams based on proximity to HWA treatments. Candidate streams were visited to determine whether the stream depth, stream substrate, and water flow speeds were suitable for sampling salamanders and stream invertebrates. Final study sites were selected based on the suitability of the streams for sampling, the proximity of treated trees, or the absence of known treatments for non-impacted sites. Sites adjacent to HWA treatments had on average $306 \pm 158.7$ occurrences of imidacloprid applications (range $=$ 5-3993 applications), with applications representing individual tree treatments. 
We sampled headwater streams for stream salamanders in 24 sites in MNF, 14 sites in NERI, and ten sites in GARI. Of these 48 sites, 27 were directly adjacent to HWA treatments and 21 were not adjacent to HWA treatments. Sites that were not adjacent to HWA treatments were either a minimum of $100 \mathrm{~m}$ upstream of imidacloprid application or were in a watershed without known HWA treatments. We selected $100 \mathrm{~m}$ as a minimum distance because Benton et al. (2015) did not detect imidacloprid in stream sites that were 10-100 m upstream of treated trees, and because Desmognathus spp. typically have home ranges smaller than $100 \mathrm{~m}$ (reviewed by Petranka 1998).

We collected and euthanized adult individuals of the salamander genus Desmognathus to quantify imidacloprid bioaccumulation and corticosterone levels from 11 of the 48 sampled sites, including seven sites in GARI and four sites in NERI. For salamander collection, we selected sites that had high densities of large adult seal salamanders (D. monticola) and northern dusky salamanders (D. fuscus). Seven sites that were sampled for stream salamanders were directly adjacent to HWA treatments and four were not. For this subset of sites, sites adjacent to HWA treatments had an average of $244.3 \pm 93.8$ occurrences of imidacloprid application (range = 17675 applications).

We also sampled benthic macroinvertebrates from 15 of the 48 sites used for salamander sampling. This subset of sites was comprised of five sites in NERI, two sites in GARI, and eight sites in MNF. For benthic macroinvertebrate collection, we selected sites with abundant riffles. All sites that were sampled for benthic macroinvertebrates were adjacent to HWA treatments.

\subsection{Water and Sediment Sampling}

We collected two liters of water from each stream in $1 \mathrm{~L}$ plastic bottles (Thermo Scientific Nalgene ${ }^{\mathrm{TM}}$ labware, Rochester, NY) without disturbing the stream sediment. Stream sediment was collected from the bottom of the stream using a trowel and enough sediment was collected to fill one quart-sized plastic bag. If the stream bottom did not have any sediment, we collected sediment from the sides of the stream bank. The trowel was wiped with $70 \%$ ethanol between each use to prevent contamination. The bottles of water and bags of sediment were placed in black bags and a backpack to prevent light exposure from metabolizing imidacloprid until the samples could be placed in a cooler with ice. The samples were stored at $4{ }^{\circ} \mathrm{C}$ from the day of collection until extraction procedures began. 


\subsection{Water and Sediment Imidacloprid Extraction and Quantification}

We adapted water and sediment extraction procedures from Baskaran et al. (1997). We filtered $1 \mathrm{~L}$ of water from each site through $0.22-\mu \mathrm{m}$ filters. We then filtered the water samples through pre-conditioned C18 solid-phase extraction (SPE) cartridges on a vacuum manifold. We eluted the imidacloprid from the cartridges with $5 \mathrm{~mL}$ acetone into $15-\mathrm{mL}$ glass test tubes and dried the eluent under nitrogen at $100^{\circ} \mathrm{C}$ and reconstituted the residue in $0.5 \mathrm{~mL}$ of acetonitrile. We then filtered the reconstituted samples through $0.20-\mu \mathrm{m}$ filters into liquid chromatography (LC) vials.

We dried sediment samples at $100^{\circ} \mathrm{C}$ for 3 days in an oven before crushing and sieving the samples. We then weighed the sediment samples to $30 \mathrm{~g}$, added $100 \mathrm{~mL}$ of deionized (DI) water, and stirred for $1 \mathrm{~min}$. We sonicated the samples for $15 \mathrm{~min}$ at room temperature and filtered the samples through cheese cloth and a $0.22-\mu \mathrm{m}$ filter. We completed the process of adding DI water and filtering twice before adjusting the final sample volume to $250 \mathrm{~mL}$ with DI water. We transferred the extract to a separatory funnel and added $25 \mathrm{~mL}$ of chloroform. We mixed the solution vigorously and extracted the chloroform layer through anhydrous sodium sulfate. We repeated this process twice before drying the solution under nitrogen at $100^{\circ} \mathrm{C}$ and reconstituting the residue in $0.5 \mathrm{~mL}$ of acetonitrile. We filtered the reconstituted samples through pre-conditioned florisil cartridges, eluted the imidacloprid using $5 \mathrm{~mL}$ of acetonitrile, and dried the eluent under nitrogen at $100^{\circ} \mathrm{C}$. We reconstituted the residue in $0.5 \mathrm{~mL}$ of acetonitrile and filtered the reconstituted samples through $0.20 \mu \mathrm{m}$ filters into LC vials

We quantified the concentration of imidacloprid in the stream sediment and water using ultra-performance liquid chromatography-tandem mass spectrometry ([UP] LC-MS/MS). We adapted the chromatographic and mass spectrometry conditions from Galeano et al. (2013). We used the Exion LC AD UHPLC system coupled with AB Sciex Qtrap 5500 triple quadrupole AcQuRate CEM detector. We separated the compounds imidacloprid, imidacloprid-urea, and imidacloprid-olefin and external standards on a Kromasil C-18 (M05CLD05) column (2.1 x 50 $\mathrm{mm}$ ) maintained at an oven temperature of $40^{\circ} \mathrm{C}$ using a mobile phase gradient of (A) $0.1 \%$ formic acid in water and (B) $0.1 \%$ formic acid in acetonitrile. We programmed the elution gradient as follows: $0-1.0 \mathrm{~min}$, isocratic $\mathrm{A}$ to $\mathrm{B}(80: 20, \mathrm{v} / \mathrm{v}) ; 1.0-1.3 \mathrm{~min}$, from A to $\mathrm{B}(80: 20$, $\mathrm{v} / \mathrm{v})$ to $\mathrm{A}-\mathrm{B}(0: 100, \mathrm{v} / \mathrm{v}) ; 1.3-2.3 \mathrm{~min}$, isocratic $\mathrm{A}$ to $\mathrm{B}(0: 100, \mathrm{v} / \mathrm{v})$; at $2.3 \mathrm{~min}$, from A-B $(0: 100$, 
$\mathrm{v} / \mathrm{v})$ to $A$ to $\mathrm{B}(80: 20, \mathrm{v} / \mathrm{v}) ; 2.3-6.0 \mathrm{~min}$, isocratic A to B $(80: 20, \mathrm{v} / \mathrm{v})$. We maintained the autosampler temperature at $10^{\circ} \mathrm{C}$ and the injection volume was $2 \mu \mathrm{L}$. The MS/MS detection of the compounds was performed by electrospray ionization (ESI) source operated in positive ion mode.

We used multiple reaction monitoring (MRM) for the detection and quantification of imidacloprid and metabolites. MRM parameters were as follows: imidacloprid, Q1 mass 256.000 Da, Q3 mass 209.000 Da, 50.0 msec; imidacloprid urea, Q1 mass 213.200 Da, Q3 mass 129.000, 50.0 msec; imidacloprid olefin, Q1 mass 254.100 Da, Q3 mass 171.000 Da, 50 msec. We maintained the IonSpray voltage and source temperature at $4.50 \mathrm{kV}$ and $450^{\circ} \mathrm{C}$, respectively. We used the LC-MS/MS software Analyst (Sciex, Version 1.6.3) for data acquisition and processing. Due to project constraints, we were unable to quantify recovery success of imidacloprid from sediment, and thus we treated sediment data as presence-absence only for this study. We note that estimated imidacloprid concentrations in sediment were minor compared to estimated concentrations in stream water (i.e., typically $<15 \%$ of the concentration in stream water). We were not able to test for presence/absence of metabolites in water for sites at NERI and GARI.

\subsection{Salamander Sampling}

Within each of the 48 sites, we established three $3.3 \times 2$ meter subplots for a total plot area of $10 \times 2$ meter. One meter of the subplot width was on the bank and one meter was within the wetted stream channel. We primarily placed subplots in riffles, but occasionally placed subplots in runs or pools if the site did not have riffle habitat. We chose subplots which were similar in terms of stream depth, substrate, canopy cover, vegetative community, and flow regime. We completed salamander sampling in the NPS sites between April and July of 2017 and in the MNF sites between April and July of 2018, sampling each site 6-7 times during the year. We conducted surveys during baseflow conditions. While moving upstream to prevent stream sediment from flowing downstream and obscuring our view, we flipped every cover object greater than $50 \mathrm{~mm}$ in diameter and searched through leaf packs.

We removed all captured salamanders and placed them in plastic bags. We identified all salamanders to species, or genus when identification to species was not possible. We weighed all captured salamanders to the nearest $0.1 \mathrm{~g}$ with a spring scale (Pesola Precision Scales, Schindellegi, Switzerland) and measured snout-vent length (SVL) and total length to the nearest 
$0.1 \mathrm{~mm}$ with dial calipers (Wiha Tools, Monticello, Minnesota, USA). We measured salamanders using a salamander stick to maximize accuracy (Margenau et al. 2018). We took note of any missing limbs or tails and if salamanders were gravid. After processing, we returned salamanders to their point of capture.

\subsection{Salamander Sampling for Corticosterone Concentration and Imidacloprid Bioaccumulation}

We hand captured 175 D. monticola and D. fuscus salamanders by flipping rocks and other cover objects in the stream between 8 July and 24 November 2017. We selectively collected large salamanders because of a minimum tissue sample requirement for imidacloprid extraction and quantification. We measured and weighed the salamanders, placed them in individual plastic bags and transferred them to the laboratory, and humanely euthanized them through exposure to carbon dioxide followed by decapitation. Salamanders were then frozen until processing for imidacloprid extraction.

We quantified plasma levels of corticosterone for a subset of the salamanders $(n=126)$. For these samples, we decapitated salamanders in the field and collected a blood sample within three minutes of initial disturbance of the salamander to minimize the influence of capture stress on corticosterone level (Romero and Reed 2005). We then transported salamanders to the laboratory, measured and weighed them, and froze them until processing for imidacloprid extraction. We centrifuged blood samples for $5 \mathrm{~min}$ and plasma was collected and stored at $20^{\circ} \mathrm{C}$ until analysis. Plasma samples packed in a cooler on dry ice and sent to the Endocrine Technology Laboratory at the Oregon National Primate Research Center (ONPRC) and assayed for corticosterone using radioimmunoassay (RIA; Thomas and Woodley 2017). Recovery was $98.8 \%$ and intra-assay coefficient of variation (CV) was $8.1 \%$.

\subsection{Benthic Macroinvertebrate and Crayfish Sampling}

We collected benthic macroinvertebrates and crayfish between 17 September and 20 November 2018. We collected individuals by placing a D-net flush with the stream bottom and disturbing the substrate upstream or by sweeping the D-net under stream overhangs. Only crayfish smaller than $2.5 \mathrm{~cm}$ were collected to ensure that they were of a size that could be consumed by a salamander. Benthic macroinvertebrates and crayfish from each site were stored 
together in a tube containing $75 \%$ ethanol and covered with foil to prevent light exposure until imidacloprid extraction.

\subsection{Salamander and Invertebrate Imidacloprid Extraction and Quantification}

We quantified imidacloprid concentrations in 164 Desmognathus salamanders (62 D. fuscus and 102 D. monticola). We adapted pesticide extraction and chromatographic and mass spectrometry conditions from procedures developed by Lehotay (2006) and Galeano et al. (2013). We placed individual salamanders and the composite invertebrate samples from each site into 50-mL tubes. We flash froze samples in liquid nitrogen and placed them in a freeze dryer for 3 days. We placed $35-\mathrm{mm}$ steel beads into each 50-mL tube and ground the salamanders and invertebrates in a Retsch MixerMill (MM 400, Haan, Germany) for 3 mins at $30 \mathrm{rep} / \mathrm{min}$. We then removed the steel beads and added $10 \mathrm{~mL}$ of deionized water and $10 \mathrm{~mL}$ of acetonitrile. Samples were briefly vortexed then sonicated for $20 \mathrm{~min}$ at room temperature in a sonication bath. We then added Quick Easy Cheap Effective Rugged Safe (QuEChERS) Mylar salt pouches (UCT, ECQUEU7-MP) to each sample, and the samples were vortexed for $10 \mathrm{sec}$ and shaken by hand for $1 \mathrm{~min}$. We centrifuged the samples at 2,200 relative centrifugal force for $5 \mathrm{~min}$. We assembled a high-throughput vacuum apparatus with clean-up cartridges (UCT, ECPSAC1856) and conditioned with $5 \mathrm{~mL}$ of acetonitrile. Eight $\mathrm{mL}$ of the organic layer (acetonitrile) of each sample was collected and cleaned through the cartridges, and deposited in 15 -mL glass test tubes. We then dried the test tubes under nitrogen at $50^{\circ} \mathrm{C}$, reconstituted them in $0.5 \mathrm{~mL}$ of acetonitrile, and filtered the samples through PTFE Whatman Mini-UniPrep Syringeless Filter vials. We followed the same procedure to quantify imidacloprid concentration as described above for water and sediment.

We calculated limit of detection (LOD) values from an external standard solution containing imidacloprid, imidacloprid-urea, and imidacloprid-olefin ranging from 5-300 ng/mL in LC-MS grade acetonitrile. We performed a linear regression on the data points in the concentration range $(n=7)$ and used the formula $3 *\left[(\mathrm{SE}) /\left(\mathrm{R}^{2}\right)\right]\left(\mathrm{SE}=\right.$ standard error, $\mathrm{R}^{2}=$ coefficient of determination) to calculate the LOD. In all sample types, the LOD values were $5.98 \mathrm{ng} / \mathrm{mL}, 33.7 \mathrm{ng} / \mathrm{mL}$, and $4.15 \mathrm{ng} / \mathrm{mL}$ for imidacloprid, imidacloprid-urea, and imidaclopridolefin, respectively. 


\subsection{Statistical Analyses}

We assessed relationships between exposure to imidacloprid and the following response variables: bioaccumulation in salamanders, bioaccumulation in invertebrates (benthic macroinvertebrates and crayfish combined), salamander corticosterone concentration, and salamander BCI score. For bioaccumulation, we assessed the influence of imidacloprid concentration in stream water on imidacloprid concentration in the salamanders and invertebrates. For salamanders, we only included individuals with detectable levels of imidacloprid or one of its metabolites. For both salamanders and invertebrates, we used the total estimated concentration of imidacloprid and its metabolites as the response variable. For sublethal effects, we assessed the influence of imidacloprid concentration in stream water and three additional predictors of imidacloprid exposure, including whether the site was adjacent to treated trees, number of applications in adjacent treated stands (a measure of treatment intensity), and whether imidacloprid was detected in the environment. We considered a site to be present for imidacloprid if imidacloprid, imidacloprid-urea, or imidacloprid-olefin was detected in either stream water or sediment, or the sampling site was located adjacent to imidacloprid-treated trees.

We created a BCI by regressing (log) SVL on (log) weight (Schulte-Hostedde et al. 2005). Positive residuals indicate a higher-than-average weight for a given SVL, and vice versa. We did not include salamanders missing portions of their tails or legs in BCI analyses. We created separate BCIs for each salamander species, and for gravid females within-species, including D. fuscus $(\mathrm{n}=207)$, D. monticola $(\mathrm{n}=274)$, D. ochrophaeus (Allegheny Mountain dusky salamander; $\mathrm{n}=141$ ), Eurycea spp. (northern and southern two-lined salamanders; $\mathrm{n}=$ 59), and Gyrinophilus porphyriticus (spring salamander; $\mathrm{n}=121$ ). We did not include larval salamanders that weighed $\leq 0.1 \mathrm{~g}$, larval Eurycea spp. because SVL was not a strong predictor of weight, or additional salamander species captured because sample sizes were small $(<20$ captures). For each BCI, we z-score transformed the data so that standard deviations were equal across species (Legendre and Legendre 2012).

We used linear regressions and a model selection approach using Akaike's Information Criterion corrected for small sample size $\left(\mathrm{AIC}_{c}\right)$ to assess the influence of imidacloprid predictors on our response variables (Burnham et al. 2011, Zuur et al. 2009). For all analyses, we assessed assumptions of normality using quantile-quantile plots and homoscedasticity using residual plots (Zuur et al. 2009, 2010). For the invertebrate bioaccumulation data set, we 
removed the two highest water concentration samples to satisfy the assumption of homoscedasticity. For the corticosterone data set, we removed the four highest corticosterone concentration samples to satisfy the assumption of normality. For the corticosterone model selection, we accounted for inherent differences in corticosterone concentration among species and sex (i.e., males, females, gravid females; Dickens and Romero 2013, Gormally et al. 2019, Scott and Ellis 2007) by including these factors in all imidacloprid models. For the BCI model selection, we did not include sex as a predictor because we did not identify sex for many of the captures, but we did include life stage (i.e., larva or adult/sub-adult). We created linear regressions using the GLS function with a constant variance structure in the package nlme (Pinheiro et al. 2016; version 3.1-137) in program R (R Core Team 2019; version 3.4.1). We gauged model support based on $\Delta \mathrm{AIC}_{c}$ and Akaike weight $\left(w_{i}\right)$, and considered candidate models to have support when $\Delta \mathrm{AIC}_{c}<7$ (Burnham et al. 2011).

\section{RESULTS}

\subsection{Water and Sediment Imidacloprid Concentration}

Of the 48 sampled sites, 27 were directly adjacent to HWA treatments (Table 1-1). Imidacloprid was detected in the stream water at 24 sites, with a mean concentration of $49.83 \pm$ $20.22 \mathrm{ng} / \mathrm{mL}$ (range $=6.52-489.56 \mathrm{ng} / \mathrm{mL}$ ). Imidacloprid-urea was not detected in the stream water at any site. We detected imidacloprid-olefin in the water at two sites, both of which had detectable levels of imidacloprid. Imidacloprid was detected in sediment at eight sites, five of which were adjacent to HWA treatments. We did not detect imidacloprid-olefin or imidaclopridurea in the sediment at any site.

\subsection{Salamander Imidacloprid Bioaccumulation}

Of the 107 salamanders tested for bioaccumulation, 29 had detectable levels of imidacloprid or imidacloprid-olefin. We detected imidacloprid in the tissues of $10 \mathrm{D}$. monticola and 4 D. fuscus, with a mean concentration of $24.63 \pm 3.55 \mathrm{ng} / \mathrm{mL}$ (range $=6.36-51.27 \mathrm{ng} / \mathrm{mL}$ ). We detected imidacloprid-olefin in the tissues of 13 D. monticola and $6 \mathrm{D}$. fuscus, with a mean concentration of $8.33 \pm 0.80 \mathrm{ng} / \mathrm{mL}$ (range $=4.16-19.78 \mathrm{ng} / \mathrm{mL}$ ). Three $D$. monticola and one $D$. fuscus had detectable levels of both imidacloprid and imidacloprid-olefin. We did not detect imidacloprid-urea in the tissues of any salamanders. We detected imidacloprid or imidacloprid- 
olefin in the tissue of three salamanders collected from sites that were not adjacent to treated trees (sites 9, 11, 32; Table 1-1). The model containing concentration of imidacloprid in stream water received higher support than the null model $\left(w_{i}=0.60\right)$. Imidacloprid concentration in salamanders increased with concentration in stream water, but the $95 \%$ confidence interval (CI) overlapped 0 ( $\beta=0.093,95 \%$ CI: $-0.013-0.199)$.

\subsection{Benthic Macroinvertebrate and Crayfish Imidacloprid Bioaccumulation}

We detected imidacloprid in all 15 benthic macroinvertebrate/crayfish samples, with a mean concentration of $26.36 \pm 3.76 \mathrm{ng} / \mathrm{mL}$ (range $=12.05-68.38 \mathrm{ng} / \mathrm{mL}$ ). We also detected imidacloprid-urea in 13 of these samples. We did not detect imidacloprid-olefin in any samples. For three sites adjacent to HWA treatments, imidacloprid was not detected in the water or sediment, but was detected in the invertebrate samples (mean concentration of these samples $=$ $26.08 \pm 4.94 \mathrm{ng} / \mathrm{mL}$; Table 1-1). The null model received higher support than the model containing concentration of imidacloprid in stream water $\left(w_{i}=0.71\right)$.

\subsection{Sublethal Effects of Imidacloprid on Salamanders}

For the corticosterone model selection, the model with the strongest support contained additive effects of species, sex, and number of imidacloprid applications in adjacent treated stands $\left(w_{i}=0.39\right.$; Table 2-1). Corticosterone concentration increased with increasing number of applications ( $\beta=0.0010,95 \%$ CI: $0.0003-0.0017)$. The second most supported model contained an interaction effect between sex and number of applications $\left(w_{i}=0.28\right)$, and indicated that effects were stronger for non-gravid females than for males and gravid females (Fig. 2-2a). Concentration of imidacloprid in stream water $\left(\Delta \mathrm{AIC}_{c}=2.77\right)$ and presence of treated trees $\left(\Delta \mathrm{AIC}_{c}=6.68\right)$ also had some support as predictors of corticosterone concentration (Table 2-1), and both estimated positive relationships.

For the BCI model selection, the model with the strongest support contained concentration of imidacloprid in stream water as a predictor $\left(w_{i}=0.44\right.$; Table 2-2). BCI decreased as concentration of imidacloprid in stream water increased $(\beta=-0.0009,95 \% \mathrm{CI}$ : $0.0017-0.0001$; Fig. 2-2b). The null model also had some support $\left(\Delta \mathrm{AIC}_{c}=2.62, w_{i}=0.12\right)$. There was no support for an interaction between species and concentration of imidacloprid in stream water $\left(\Delta \mathrm{AIC}_{c}=12.35\right)$. For all 5 species, mean BCI score was lower at sites with presence 
of imidacloprid in the environment, and median BCI score was lower for 4 of the species (Fig. 23).

\section{DISCUSSION}

This study provides strong evidence that salamanders and stream invertebrates uptake imidacloprid that leaches into their environment from treated hemlock stands. Our concurrent research demonstrated that terrestrial spotted salamanders uptake imidacloprid dermally (Appendix 2-1). In this study, we found that benthic macroinvertebrates and crayfish, which are both important prey sources of stream salamanders, can also bioaccumulate imidacloprid. Thus, prey consumption may represent an additional route of imidacloprid exposure for salamanders. However, additional research is needed to confirm if salamanders bioaccumulate imidacloprid after consuming contaminated prey.

Corticosterone in D. monticola and D. fuscus was positively associated with number of imidacloprid applications, and this effect was the strongest for non-gravid females. Conclusions from previous studies investigating pesticide-associated changes in corticosterone levels are conflicted. For example, larval western tiger salamanders (Ambystoma mavortium) had higher corticosterone levels in agricultural wetlands with elevated levels of neonicotinoid insecticides, compared to reference wetlands (Davis et al. In Press). In contrast, wood frog (Lithobates sylvaticus) tadpoles experimentally exposed to environmentally relevant concentrations of the neonicotinoid thiamethoxam had lower corticosterone concentrations, and there was no difference in corticosterone concentrations in juveniles (Gavel et al. 2019). Male African clawed frogs (Xenopus laevis) had elevated corticosterone concentrations when exposed to the pesticide concoction (Hayes et al. 2006). Additional studies are needed to determine if corticosterone responses to imidacloprid exposure are predictable based on species, sex, and life stage.

We found that salamander BCI was negatively associated with imidacloprid concentration in stream water, and BCI was lower in streams with environmental imidacloprid for all five species. Body condition is an important indicator of amphibian health and correlates with survival, productivity, and movement dynamics (e.g., Lowe et al. 2006, Reading 2007, Roznik et al. 2015). For example, body condition is correlated to territory size and number of prey within territories (Gabor 1995) and larger body size is advantageous in mate competition 
(Howard et al. 1997). Our results suggest that HWA treatments can negatively effect the health of individual salamanders.

Interestingly, we found imidacloprid in the tissues of invertebrates from three sites where we did not detect imidacloprid in the stream water or sediment. Presence of imidacloprid in stream water varies temporally and increases after rain events (Churchel et al. 2011, Cowles et al. 2009, McGrath et al. 2010). Grab sampling of stream water for pesticide runoff research does not account for spatial and temporal variation and can lead to underestimates of pesticide residues (Xing et al. 2013). Our results suggest that sampling stream invertebrates may be more reliable than sampling stream water to confirm presence of imidacloprid in streams. However, we recognize that our sample size was small, and we were unable to assess temporal dynamics in our data sets. Additional research on this topic is warranted.

Three sites that were not directly adjacent to HWA treatments contained salamanders with detectable levels of imidacloprid or imidacloprid-olefin. One of these sites was located downstream of farmland and we did detect imidacloprid in the stream sediment. Imidacloprid is commonly used in agriculture (Elbert et al. 2008), and thus leaching from upstream farmland may explain presence of imidacloprid at this site. Similarly, another site was near private homes, and imidacloprid is used in residential areas for treating ornamental trees and for termite control (McCullough et al. 2005, Parman and Vargo 2010). However, we did not detect imidacloprid in the stream water or sediment at this site. The third site was located $100 \mathrm{~m}$ upstream of a known treatment site, and we speculate that the salamander traveled upstream following exposure to imidacloprid.

In summary, this research indicates that treating hemlock stands adjacent to streams with imidacloprid can result in the pesticide entering aquatic food webs, and can result in sublethal effects on salamanders. Imidacloprid is one of the world's most widely used pesticides, with heavy application in agricultural, urban, and forest systems. Given the widespread use of imidacloprid and documented bioaccumulation in invertebrate and vertebrate organisms, additional studies investigating potential biomagnification in food webs are warranted.

\section{ACKNOWLEDGMENTS}

Funding for this research was provided by the U.S. Geological Survey-National Park Service Water Quality Partnership Program, the Foundation for the Conservation of Salamanders, and 
the West Virginia University Program to Stimulate Competitive Research. The West Virginia Division of Natural Resources and National Park Service provided field housing. The WV Cooperative Fish and Wildlife Research Unit provided field vehicles. We thank Dr. Terrance McManus, Dr. Kang Mo Ku, and Tyler Simpson for assistance with chemical analyses. We thank Allison Fulcher and Sam Wilson for assistance with water and sediment collection, Zachary Dienes and Jaewon Kim for assistance with collecting benthic macroinvertebrates, and Devin Hoffer and Iris Allen for assistance with collecting salamanders. Donald Brown was supported by the USDA National Institute of Food and Agriculture, McIntire Stennis project WVA00122, and the West Virginia Agricultural and Forestry Experiment Station. Capture and handling methods were approved by the West Virginia Division of Natural Resources (Permit \#: 2017.073, 2017.096), National Park Service (Permit \#: NERI-2017-SCI-0002 and GARI-2017SCI-0001), and West Virginia University Institutional Animal Care Use Committee (Protocol \#: 1602000309_R1). Any use of trade, product, or firm names is for descriptive purposes only and does not imply endorsement by the U.S. Government.

\section{LITERATURE CITED}

Ade, C.M., Boone, M.D., Puglis, H.J. 2010. Effects of an insecticide and potential predators on green frogs and northern cricket frogs. Journal of Herpetology, 44(4): 591-601.

Adelizzi, R., Portmann, J., Van Meter, R. 2019. Effect of individual and combined treatments of pesticide, fertilizer, and salt on growth and corticosterone levels of larval southern leopard frogs (Lithobates sphenocephala). Archives of Environmental Contamination and Toxicology, 2019: 1-11.

Alexander, A.C., Culp, J.M., Liber, K., Cessna, A.J. 2007. Effects of insecticide exposure on feeding inhibition in mayflies and oligochaetes. Environmental Toxicology and Chemistry, 26(8): 1726-1732.

Baskaran, S., Kookana, R.S., Naidu, R. 1997. Determination of the insecticide imidacloprid in water and soil using high-performance liquid chromatography. Journal of Chromatography A, 787(1-2): 271-275.

Becker, D.A., Brittingham, M.C., Goguen, C.B. 2008. Effects of hemlock woolly adelgid on breeding birds at Fort Indiantown Gap, Pennsylvania. Northeastern Naturalist, 15(2): $227-240$.

Benton, E.P., Grant, J.F., Mueller, T.C., Webster, R.J., Nichols, R.J. 2016. Consequences of imidacloprid treatments for hemlock woolly adelgid on stream water quality in the southern Appalachians. Forest Ecology and Management, 360(2016): 152-158. 
Benton, E.P., Grant, J.F., Nichols, R.J., Webster, R.J., Schwartz, J.S., Bailey, J.K. 2017. Risk assessment of imidacloprid use in forest settings on the aquatic macroinvertebrate community. Environmental Toxicology and Chemistry, 36(11): 3108-3119.

Benton, E.P., Grant, J.F., Webster, R.J., Nichols, R.J., Cowles, R.S., Lagalante, A.F., Coots, C.I. 2015. Assessment of imidacloprid and its metabolites in foliage of eastern hemlock multiple years following treatment for hemlock woolly adelgid, Adelges tsugae (Hemiptera: Adelgidae), in forested conditions. Journal of Economic Entomology, 108(6): 2672-2682.

Burnham, K.P., Anderson, D.R., Huyvaert, K.P. 2011. AIC model selection and multimodel inference in behavioral ecology: some background, observations, and comparisons. Behavioral Ecology and Sociobiology 65: 23-35.

Burton, T.M., Likens, G.E. 1975. Salamander populations and biomass in the Hubbard Brook Experimental Forest, New Hampshire. Copeia, 1975(3): 541-546.

Chambers, D.L., Wojdak, J.M., Du, P., Belden, L.K. 2013. Pond acidification may explain differences in corticosterone among salamander populations. Physiological and Biochemical Zoology, 86(2): 224-232.

Charbonnier, J.F., Pearlmutter, J., Vonesh, J.R., Gabor, C.R, Forsburg, Z.R., Grayson, K.L. 2018. Cross-life stage effects of aquatic larval density and terrestrial moisture on growth and corticosterone in the spotted salamander. Diversity, 10(3): 68.

Churchel, M.A., Hanula, J.L., Berisford, C.W., Vose, J.M., Dalusky, M.J. 2011. Impact of imidacloprid for control of hemlock woolly adelgid on nearby aquatic macroinvertebrate assemblages. Southern Journal of Applied Forestry, 35(1): 26-32.

Colombo, V., Mohr, S., Berghahn, R., Pettigrove, V.J. 2013. Structural changes in a macrozoobenthos assemblage after imidacloprid pulses in aquatic field-based microcosms. Archives of Environmental Contamination and Toxicology, 65(4): 683-692.

Cooperman, M.D., Reed, J.M., Romero, L.M. 2004. The effects of terrestrial and breeding densities on corticosterone and testosterone levels in spotted salamanders, Ambystoma maculatum. Canadian Journal of Zoology, 82(11): 1795-1803.

Cowles, R.S. 2009. Optimizing dosage and preventing leaching of imidacloprid for management of hemlock woolly adelgid in forests. Forest Ecology and Management, 257(3): 10261033.

Daley, M.J., Phillips, N.G., Pettijohn, C., Hadley, J.L. 2007. Water use by eastern hemlock (Tsuga canadensis) and black birch (Betula lenta): implications of effects of the hemlock woolly adelgid. Canadian Journal of Forest Research, 37(10): 2031-2040.

Davic, R.D., Welsh, H.H. 2004. On the ecological roles of salamanders. Annual Review of Ecology, Evolution, and Systematics, 35(2004): 405-434.

Davis, D.R., Ferguson, K.J., Schwarz, M.S., Kerby, J.L. In press. Effects of agricultural pollutants on stress hormones and viral infection in larval salamanders. Wetlands.

Dickens, M.J., Romero, L.M. 2013. A consensus endocrine profile for chronically stressed wild animals does not exist. General and Comparative Endocrinology, 191(2013): 177-189. 
Elbert, A., Haas, M., Springer, B., Thielert, W., Nauen, R. 2008. Applied aspects of neonicotinoid uses in crop protection. Pest Management Science, 64(11): 1099-1105.

Elbert, A., Nauen, R., Leicht, W. 1998. Imidacloprid, a novel chloronicotinyl insecticide: biological activity and agricultural importance. In Insecticides with novel modes of action (pp. 50-73). Springer, Berlin, Heidelberg.

Ellison, A.M. 2014. Experiments are revealing a foundation species: a case study of eastern hemlock (Tsuga canadensis). Advances in Ecology, 2014: article 456904.

Feng, S., Kong, Z., Wang, X., Zhao, L., Peng, P. 2004. Acute toxicity and genotoxicity of two novel pesticides on amphibian, Rana N. Hallowell. Chemosphere, 56(5): 457-463.

Gabor, C.R. 1995. Correlational test of Mathis' hypothesis that bigger salamanders have better territories. Copeia, 729-729.

Gabor, C.R., Knutie, S.A., Roznik, E.A., Rohr, J.R. 2018. Are the adverse effects of stressors on amphibians mediated by their effects on stress hormones? Oecologia, 186(2): 393-404.

Galeano, M., Scordino, M., Sabatino, L., Pantò, V., Morabito, G., Chiappara, E., Traulo, P., Gagliano, G. 2013. UHPLC/MS-MS analysis of six neonicotinoids in honey by modified QuEChERS: method development, validation, and uncertainty measurement. International Journal of Food Science, 2013: 1-7.

Gavel, M.J., Richardson, S.D., Dalton, R.L., Soos, C.E., Ashby, B., McPhee, L., Forbes, M.R. and Robinson, S.A. 2019. Effects of two neonicotinoid insecticides on blood cell profiles and corticosterone concentrations of wood frogs (Lithobates sylvaticus). Environmental toxicology and chemistry, 2019(38): 1273-1284.

Gibbons, D., Morrissey, C., Mineau, P. 2015. A review of the direct and indirect effects of neonicotinoids and fipronil on vertebrate wildlife. Environmental Science and Pollution Research, 22(1): 103-118.

Glennemeier, K.A., Denver, R.J. 2002. Role for corticoids in mediating the response of Rana pipiens tadpoles in intraspecific competition. Journal of Experimental Zoology, 292(1): $32-40$.

Glinski, D.A., Henderson, W.M., Van Meter, R.J., Purucker, S.T. 2018. Effect of hydration status on pesticide uptake in anurans following exposure to contaminated soils. Environmental Science and Pollution Research, 2018: 1-10.

Gormally, B.M., Fuller, R., McVey, M., Romero, L.M. 2019. DNA damage as an indicator of chronic stress: correlations with corticosterone and uric acid. Comparative Biochemistry and Physiology Part A: Molecular \& Integrative Physiology, 227: 116-122.

Hadley, J.L., Schedlbauer, J.L. 2002. Carbon exchange of an old-growth eastern hemlock (Tsuga canadensis) forest in central New England. Tree Physiology, 22(15-16): 1079-1092.

Hallmann, C.A., Foppen, R.P., van Turnhout, C.A., de Kroon, H., Jongejans, E. 2014. Declines in insectivorous birds are associated with high neonicotinoid concentrations. Nature, 511 (7509): 341-343. 
Havill, N.P., Vieira, L.C., Salom, S.M. 2014. Biology and control of hemlock woolly adelgid. USDA Forest Service, Forest Health Technology Enterprise Team, Morgantown, West Virginia.

Hayes, T.B., Case, P., Chui, S., Chung, D., Haeffele, C., Haston, K., Lee, M., Mai, V.P., Marjuoa, Y., Parker, J., Tsui, M. 2006. Pesticide mixtures, endocrine disruption, and amphibian declines: are we underestimating the impact? Environmental Health Perspectives, 114(Suppl 1): 40-50.

Hayes, T.B., Falso, P., Gallipeau, S., Stice, M. 2010. The cause of global amphibian declines: a developmental endocrinologist's perspective. Journal of Experimental Biology, 213(6): 921-933.

Hopkins, W.A., Mendonça, M.T., Congdon, J.D. 1997. Increased circulating levels of testosterone and corticosterone in southern toads, Bufo terrestris, exposed to coal combustion waste. General and Comparative Endocrinology, 108(2): 237-246.

Howard, R.D., Moorman, R.S., Whiteman, H.H. 1997. Differential effects of mate competition and mate choice on eastern tiger salamanders. Animal Behaviour, 53(6): 1345-1356.

Krapfl, K.J., Holzmueller, E.J., Jenkins, M.A. 2011. Early impacts of hemlock woolly adelgid in Tsuga canadensis forest communities of the southern Appalachian Mountains. Journal of the Torrey Botanical Society 138(1): 93-106.

Kreutzweiser, D.P., Good, K.P., Chartrand, D.T., Scarr, T.A., Thompson, D.G. 2008. Toxicity of the systemic insecticide, imidacloprid, to forest stream insects and microbial communities. Bulletin of Environmental Contamination and Toxicology, 80(3): 211-214.

Kreutzweiser, D.P., Thompson, D.G., Scarr, T.A. 2009. Imidacloprid in leaves from systemically treated trees may inhibit litter breakdown by non-target invertebrates. Ecotoxicology and Environmental Safety, 72(4): 1053-1057.

Larson, D.L., McDonald, S., Hamilton, S.J., Fivizzani, A.J., Newton, W.E. 1998. Effects of the herbicide atrazine on Ambystoma tigrinum metamorphosis: duration, larval growth, and hormonal response. Physiological Zoology, 71(6): 671-679.

Legendre, P., Legendre, L. 2012. Numerical Ecology. Third edition. Elsevier, Amsterdam, The Netherlands.

Lehotay, S. 2006. Quick, easy, cheap, effective, rugged, and safe approach for determining pesticide residues. Pages 239-261 in J. L. Martínez Vidal and A. Garrido Frenich, editors. Pesticide protocols, Humana Press, New York, New York, USA.

Lowe, W.H., Likens, G.E., Cosentino, B.J. 2006. Self-organization in streams: the relationship between movement behaviour and body condition in a headwater salamander. Freshwater Biology, 51(11): 2052-2062.

Margenau, E.L., Crayton, S.M., Rucker, L.E., Jacobsen, C.D., Brown, D.J. 2018. Modified salamander stick to facilitate accurate measurement of small individuals. Herpetological Review, 49(2): 243-246.

Mathewson, B. 2009. The relative abundance of eastern red-backed salamanders in eastern hemlock-dominated and mixed deciduous forests at Harvard Forest. Northeastern Naturalist, 16(1): 1-12. 
Matsuda, K., Buckingham, S.D., Kleier, D., Rauh, J.J., Grauso, M., Sattelle, D.B. 2001. Neonicotinoids: insecticides acting on insect nicotinic acetylcholine receptors. Trends in Pharmacological Sciences, 22(11): 573-580.

McCullough, D.G., Cappaert, D., Poland, T.M., Lewis, P., Molongoski, J. 2005. Long-term (three-year) results of truck injections for emerald ash borer control in landscape ash trees. Emerald Ash Borer Research and Technology Development, 2005: 31.

McEwen, B.S., Wingfield, J.C. 2003. The concept of allostasis in biology and biomedicine. Hormones and Behavior, 43(1): 2-15.

McGrath, G., Hinz, C., Sivapalan, M. 2010. Assessing the impact of regional rainfall variability on rapid pesticide leaching potential. Journal of Contaminant Hydrology, 113(1-4): 5665.

Millikin, A.R., Woodley, S.K., Davis, D.R., Anderson, J.T. 2019. Habitat characteristics in created vernal pools impact spotted salamander water-borne corticosterone levels. Wetlands, 2019: 1-12.

Novarro, A.J., Gabor, C.R., Goff, C.B., Mezebish, T.D., Thompson, L.M., Grayson, K.L. 2018. Physiological responses to elevated temperature across the geographic range of a terrestrial salamander. Journal of Experimental Biology, 221: jeb178236.

Parman, V., Vargo, E.L. 2010. Colony-level effects of imidacloprid in subterranean termites (Isoptera: Rhinotermitidae). Journal of Economic Entomology, 103(3): 791-798.

Pérez-Iglesias, J.M., de Arcaute, C.R., Nikoloff, N., Dury, L., Soloneski, S., Natale, G.S., Larramendy, M.L. 2014. The genotoxic effects of the imidacloprid-based insecticide formulation Glacoxan Imida on Montevideo tree frog Hypsiboas pulchellus tadpoles (Anura, Hylidae). Ecotoxicology and Environmental Safety, 104(2014): 120-126.

Petranka, J.W. 1998. Salamanders of the United States and Canada. Smithsonian Institute Press, Washington, D.C., USA.

Petranka, J. W., Murray, S. S. 2001. Effectiveness of removal sampling for determining salamander density and biomass: a case study in an Appalachian streamside community. Journal of Herpetology, 35(1): 36-44.

Pinheiro, J., Bates, D., DebRoy, S., Heisterkamp, S., Van Willigen, B. 2016. Package “nlme.” Fit and compare Gaussian linear and nonlinear mixed-effects models. Available at https://web.archive.org/web/20190706154601/https://cran.rproject.org/web/packages/nlme/nlme.pdf.

R Core Team. 2019. R: a language and environment for statistical computing. R Foundation for Statistical Computing, Vienna, Austria. URL https://web.archive.org/web/20190706154601/https://cran.rproject.org/web/packages/nlme/nlme.pdf

Reading, C.J. 2007. Linking global warming to amphibian declines through its effects on female body condition and survivorship. Oecologia, 151(1): 125-131.

Romero, L.M. 2004. Physiological stress in ecology: lessons from biomedical research. Trends in Ecology and Evolution, 19(5): 249-255. 
Romero, L.M., Reed, J.M. 2005. Collecting baseline corticosterone samples in the field: is under 3 min good enough? Comparative Biochemistry and Physiology, Part A 140(1): 73-79.

Roznik, E.A., Sapsford, S.J., Pike, D.A., Schwarzkopf, L., Alford, R.A. 2015. Conditiondependent reproductive effort in frogs infected by a widespread pathogen. Proceedings of the Royal Society B: Biological Sciences, 282(1810): 20150694.

Schulte-Hostedde, A. I., Zinner, B., Millar, J.S., Hickling, G.J. 2005. Restitution of mass-size residuals: validating body condition indices. Ecology, 86(1): 155-163.

Scott A.P., Ellis T. 2007. Measurement of fish steroids in water-a review. General and Comparative Endocrinology, 153(1-3): 392-400.

Snyder, C.D., Young, J.A., Lemarié, D.P., Smith, D.R. 2002. Influence of eastern hemlock (Tsuga canadensis) forests on aquatic invertebrate assemblages in headwater streams. Canadian Journal of Fisheries and Aquatic Sciences, 59(2): 262-275.

Thomas, J.R., Woodley, S.K. 2017. Testing the immunocompetence handicap hypothesis: testosterone manipulation does not affect wound healing in male salamanders. General and Comparative Endocrinology, 247(2017): 8-15.

Tingley, M.W., Orwig, D.A., Field, R., Motzkin, G. 2002. Avian response to removal of a forest dominant: consequences of hemlock woolly adelgid infestations. Journal of Biogeography, 29(10-11): 1505-1516.

Troïanowski, M., Mondy, N., Dumet, A., Arcanjo, C., Lengagne, T. 2017. Effects of traffic noise on tree frog stress levels, immunity, and color signaling. Conservation Biology 31(5): $1132-1140$.

Van Meter, R.J., Adelizzi, R., Glinski, D.A. and Henderson, W.M., 2019. Agrochemical mixtures and amphibians: the combined effects of pesticides and fertilizer on stress, acetylcholinesterase activity and bioaccumulation in a terrestrial environment. Environmental Toxicology and Chemistry, 38(5): 1052-1061.

Van Meter, R.J., Glinski, D.A., Henderson, W.M., Garrison, A.W., Cyterski, M., Purucker, S.T. 2015. Pesticide uptake across the amphibian dermis through soil and overspray exposures. Archives of Environmental Contamination and Toxicology, 69(4): 545-556.

Van Meter, R.J., Glinski, D.A., Hong, T., Cyterski, M., Henderson, W.M., Purucker, S.T. 2014. Estimating terrestrial amphibian pesticide body burden through dermal exposure. Environmental Pollution, 193(2013): 262-268.

Vose, J.M., Wear, D.N., Mayfield III, A.E., Nelson. C.D. 2013. Hemlock woolly adelgid in the southern Appalachians: control strategies, ecological impacts, and potential management responses. Forest Ecology and Management, 291(2013): 209-219.

Webb, R.E., Frank, J.R., Raupp, M.J. 2003. Eastern hemlock recovery from hemlock woolly adelgid damage following imidacloprid therapy. Journal of Arboriculture, 29(5): 298302.

Wiggins, G., Benton, E., Grant, J., Kerr, M., Lambdin, P. 2018. Short-term detection of imidacloprid in streams after applications in forests. Journal of Environmental Quality, 47(3): 571-578. 
Willson, J.D., Hopkins, W.A., Bergeron, C.M., Todd, B.D. 2012. Making leaps in amphibian ecotoxicology: translating individual-level effects of contaminants to population viability. Ecological Applications, 22(2012): 1791-1802.

Xing, Z., Chow, L., Rees, H., Meng, F., Li, S., Ernst, B., Benoy, G., Zha, T., Hewitt, L.M. 2013. Influences of sampling methodologies on pesticide-residue detection in stream water. Archives of Environmental Contamination and Toxicology, 64(2): 208-218.

Yamamoto, I., Casida, J.E., eds. 1999. Nicotinoid insecticides and the nicotinic acetylcholine receptor. Springer Verlag, Tokyo, Japan.

Yap, T.A., Koo, M.S., Ambrose, R.F., Wake, D.B., Vredenburg, V.T. 2015. Averting a North American biodiversity crisis. Science, 349(6247): 481-482.

Zuur, A.F., Ieno, E.N., Elphick, C.S. 2010. A protocol for data exploration to avoid common statistical problems. Methods in Ecology and Evolution, 2010(1): 3-14.

Zuur, A.F., Ieno, E.N., Walker, N.J., Saveliev, A.A., Smith, G.M. 2009. Mixed effects models and extensions in ecology with R. Springer, New York, New York, USA. 
Table 2-1. Model selection results for the influence of species (Desmognathus fuscus [northern dusky salamander] and D. monticola [seal salamander]), sex (males, females, and gravid females), and imidacloprid exposure on salamander corticosterone concentration. We sampled 119 salamanders (115 included in the analysis) at Gauley River National Recreational Area (GARI) and New River Gorge National River (NERI) in West Virginia, USA. We tested four predictors of imidacloprid exposure, including whether the site was adjacent to treated trees (Trees), number of applications in adjacent treated stands (Number), whether imidacloprid was detected in the environment (Presence), and concentration in the stream water $(\mathrm{ng} / \mathrm{mL}$; Concentration). We used Akaike's Information Criterion corrected for small sample size ( $\left.\mathrm{AIC}_{c}\right)$ to rank candidate models. The null model is shown as (.) and includes only the intercept. Akaike weights are represented as $w_{i}$.

\begin{tabular}{|l|c|r|r|r|r|}
\hline Model & Parameters & AIC $_{\boldsymbol{c}}$ & $\Delta \mathbf{A I C}_{\boldsymbol{c}}$ & $\mathbf{A d j}^{2} \mathbf{R}^{2}$ & $\mathbf{w}_{\mathbf{i}}$ \\
\hline Species + Sex + Number & 6 & 311.55 & 0.00 & 0.15 & 0.39 \\
\hline Species + Sex $\times$ Number & 8 & 312.20 & 0.65 & 0.16 & 0.28 \\
\hline Sex + Species $\times$ Number & 7 & 313.82 & 2.27 & 0.14 & 0.13 \\
\hline Species + Sex + Concentration & 6 & 314.32 & 2.77 & 0.13 & 0.10 \\
\hline Species $\times$ Sex & 7 & 315.19 & 3.64 & 0.13 & 0.06 \\
\hline Species + Sex & 5 & 317.93 & 6.38 & 0.09 & 0.02 \\
\hline Species + Sex + Trees & 6 & 318.23 & 6.68 & 0.10 & 0.01 \\
\hline Species + Sex + Presence & 6 & 319.94 & 8.39 & 0.09 & 0.01 \\
\hline Species & 3 & 321.46 & 9.91 & 0.05 & 0.00 \\
\hline Sex & 4 & 321.93 & 10.38 & 0.05 & 0.00 \\
\hline$()$. & 2 & 325.90 & 14.35 & NA & 0.00 \\
\hline
\end{tabular}


Table 2-2. Model selection results for the influence of species, age (larva or adult/sub-adult), and imidacloprid exposure on salamander body condition index (BCI) score. We standardized BCI scores for each species and thus did not include species as an independent factor in the model selection. Species included Desmognathus fuscus (northern dusky salamander), D. monticola (seal salamander), D. ochrophaeus (Allegheny Mountain dusky salamander), Eurycea spp. (northern and southern two-lined salamanders), and G. porphyriticus (spring salamander). We tested four predictors of imidacloprid exposure, including whether the site was adjacent to treated trees (Trees), number of applications in adjacent treated stands (Number), whether imidacloprid was detected in the environment (Presence), and concentration $(\mathrm{ng} / \mathrm{mL})$ in the stream water (Concentration). We used Akaike's Information Criterion corrected for small sample size $\left(\mathrm{AIC}_{c}\right)$ to rank candidate models. The null model is shown as (.) and includes only the intercept. Akaike weights are represented as $w_{i}$.

\begin{tabular}{|l|c|r|r|r|r|}
\hline Model & Parameters & AIC $_{\boldsymbol{c}}$ & $\Delta \mathbf{A I C}_{\boldsymbol{c}}$ & $\mathbf{A d j}^{\mathbf{2}}$ & $\boldsymbol{w}_{\boldsymbol{i}}$ \\
\hline Concentration & 3 & 2269.34 & 0.00 & 0.005 & 0.44 \\
\hline$()$. & 2 & 2271.95 & 2.62 & $\mathrm{NA}$ & 0.12 \\
\hline Presence & 3 & 2272.00 & 2.67 & 0.001 & 0.12 \\
\hline Number & 3 & 2272.18 & 2.84 & 0.001 & 0.11 \\
\hline Trees & 3 & 2272.44 & 3.10 & 0.001 & 0.09 \\
\hline Life Stage $\times$ Concentration & 5 & 2273.15 & 3.81 & 0.002 & 0.07 \\
\hline Life Stage & 3 & 2273.77 & 4.43 & -0.001 & 0.05 \\
\hline Species $\times$ Concentration & 11 & 2281.69 & 12.35 & -0.001 & 0.00 \\
\hline
\end{tabular}



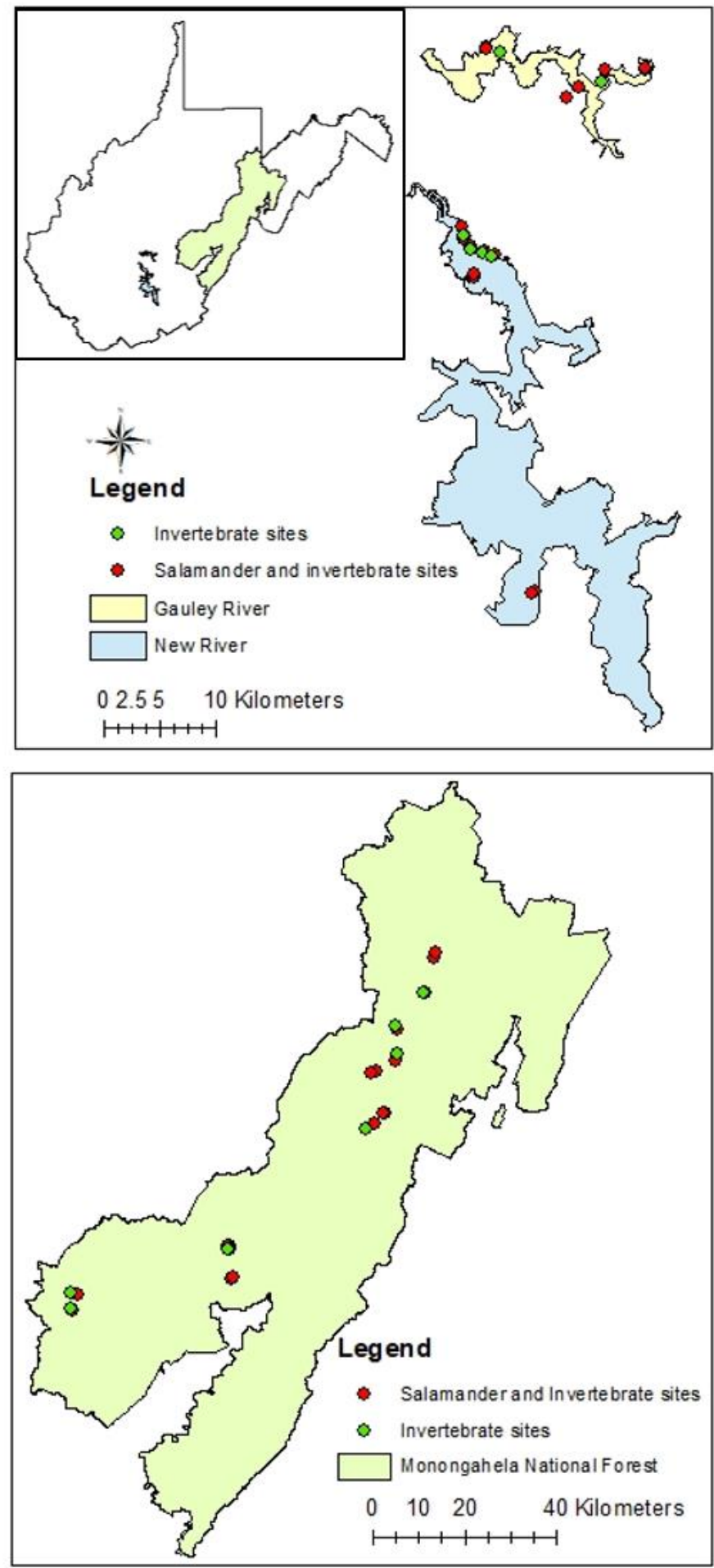

Figure 2-1. Map of study sites to investigate bioaccumulation of imidacloprid and its metabolites in stream salamanders and invertebrates, and sublethal impacts of imidacloprid on salamanders. West Virginia, USA (insert). 

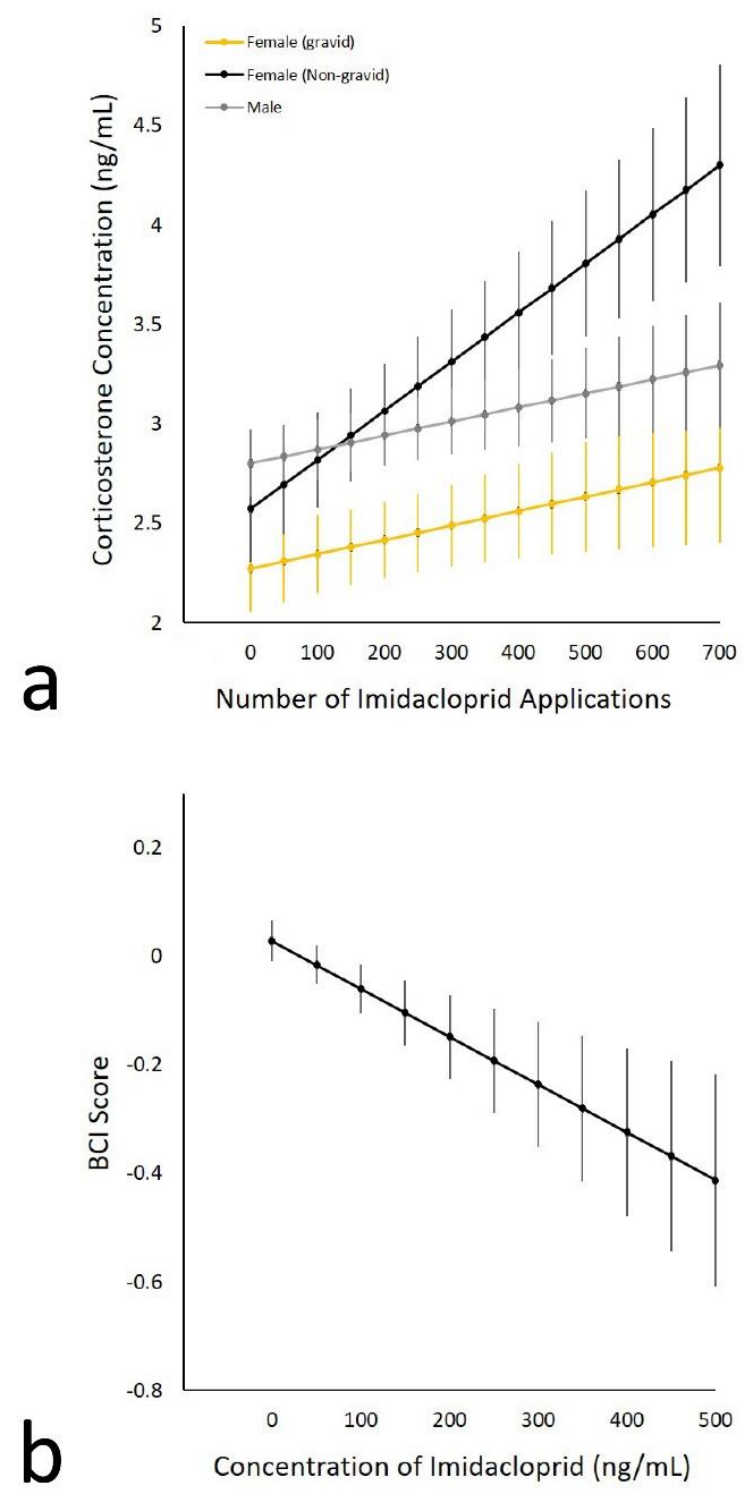

Figure 2-2. Potential sublethal effects of imidacloprid exposure on stream salamanders in West Virginia, USA. (a) Model-estimated relationship between concentration of the hormone corticosterone and total number of imidacloprid applications at the sampling site for male, nongravid female, and gravid female Desmognathus spp. $(\mathrm{n}=115)$. The intercepts represent $D$. fuscus (northern dusky salamander). (b) Model-estimated relationship between salamander body condition index (BCI) score and concentration of imidacloprid in stream water. BCI analyses included 802 individuals representing 5 species. Bars represent model standard errors. 


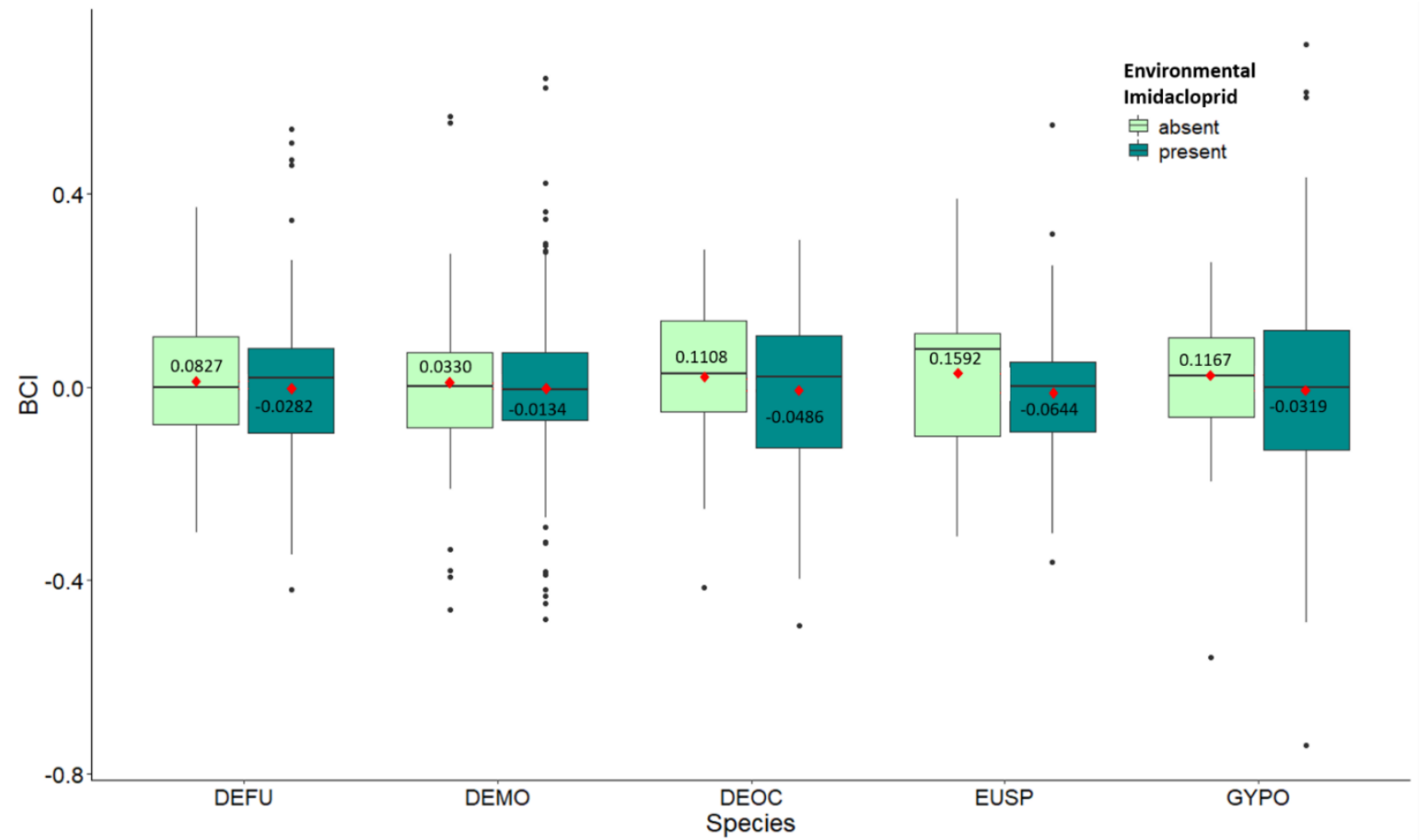

Figure 2-3. Boxplot summaries of body condition index (BCI) values used in this study assessing potential sublethal effects of imidacloprid exposure on D. fuscus (DEFU, absent, $\mathrm{n}=54$, present, $\mathrm{n}=153)$, D. monticola (DEMO, absent, $\mathrm{n}=79$, present, $\mathrm{n}=195)$, D. ochrophaeus $(\mathrm{DEOC}$, absent, $\mathrm{n}=43$, present, $\mathrm{n}=98$ ), Eurycea spp. adults (EUSP, absent, $\mathrm{n}=17$, present, $\mathrm{n}=42$ ), and G. porphyriticus (GYPO, absent, $\mathrm{n}=26$, present, $\mathrm{n}=95$ ). Mean BCI is indicated with a red circle and generally was lower in streams with imidacloprid present in the environment for each species tested. 
Appendix 2-1. Dermal Uptake and Sublethal Effects on Spotted Salamanders (Ambystoma maculatum) from Exposure to Soil Containing High Concentrations of Imidacloprid

\begin{abstract}
The neonicotinoid pesticide imidacloprid is widely applied in natural systems to manage the spread and impact of nonnative forest insects, such as the hemlock woolly adelgid (Adelges tsugae). While application of this pesticide is an effective management tool for native tree preservation, previous research has identified negative impacts on non-target invertebrates and vertebrates. However, few studies have assessed vulnerability of amphibians to imidacloprid exposure, particularly in the terrestrial environment. We conducted a laboratory experiment using terrestrial juvenile spotted salamanders (Ambystoma maculatum) to determine if exposure of salamanders to soil contaminated with high concentrations of imidacloprid resulted in bioaccumulation of the pesticide and detectable sublethal effects. We assessed two soil imidacloprid concentrations and exposed salamanders for 1-18 days. We found that terrestrial spotted salamanders were capable of uptaking imidacloprid through dermal exposure, and that soil imidacloprid concentration and number of days of exposure were positively correlated with the concentration of imidacloprid in salamanders. We also found that soil imidacloprid concentration and number of days of exposure were negatively associated with salamander body condition and prey consumption. The results of this study indicate that salamanders inhabiting forest soil with high levels of imidacloprid, such as soil drench or injection application points, could be negatively impacted by the pesticide. However, soil drench and injection zones represent a small proportion of total forest surfaces, and soil imidacloprid concentration decreases with time since application and distance from application. Additional research is needed to assess impacts of long-term exposure to low soil imidacloprid concentrations on terrestrial salamanders.
\end{abstract}

\title{
1. INTRODUCTION
}

Many forest ecosystems in the United States are being impacted by nonnative insects that damage or kill native trees, such as the emerald ash borer (Agrilus planipennis), European gypsy moth (Lymantria dispar dispar), and hemlock woolly adelgid (Adelges tsugae; Lovett et al. 2016). A variety of biological, chemical, silvicultural, and cultural management approaches have 
been implemented to manage the spread and impacts of nonnative forest insects (e.g., Webb et al. 2003, Lamb et al. 2006, Muzika 2017). One of the most common approaches is application of systemic insecticides through soil drenches, injections, or tablets (Kovacs et al. 2010, Meng et al. 2015), with imidacloprid being the most widely used insecticide for management of hemlock woolly adelgid infestations (Dilling et al. 2010, Turcotte et al. 2017). Soil treatments are substantially more effective than trunk injections, and are thus recommended (Cowles et al. 2006, Cowles and Lagalante 2009).

While the use of imidacloprid is an effective management tool for hemlock (Tsuga spp.) preservation (Webb et al. 2003), a thorough understanding of the potential non-target impacts of using the pesticide is needed. Imidacloprid is a neonicotinoid, a group of pesticides that act as neurotoxicants in insects (Jeschke and Nauen 2008). Neonicotinoids are generally considered low-risk pesticides for vertebrates because they are highly selective for insect nicotinic acetylcholine receptors (Jeschke et al. 2011, Simon-Delso et al. 2015). However, previous studies have documented lethal and sublethal effects when exposing vertebrates to environmentally-relevant concentrations of imidacloprid (reviewed by Gibbons et al. 2015). In an agricultural system, surface water concentrations of just $0.02 \mathrm{ng} / \mathrm{mL}$ were associated with local declines in insectivorous birds (Hallmann et al. 2014). Adult red-legged partridges (Alectoris rufa) that were fed seeds coated with imidacloprid at the dose recommended for cereal seed coating exhibited reduced body condition, fertility, and chick survival rates (Lopez-Antia et al. 2013). In an extreme case, 26 American Goldfinches (Spinus tristis) died from consuming seeds contaminated with imidacloprid following soil drench applications in a California suburb (Rogers et al. 2019). Importantly, several metabolites of imidacloprid may have higher toxicity to vertebrates than imidacloprid (reviewed by Wang et al. 2018).

Few studies have investigated non-target impacts of imidacloprid on amphibians, and most previous research focused on assessing lethal concentrations and genotoxicity to anuran tadpoles (e.g., Feng et al. 2004, Pérez-Iglesias et al. 2014, Ruiz de Arcaute et al. 2014). The Appalachian region is a global biodiversity hotspot for salamanders (Buckley and Jetz 2007, Rissler and Smith 2010), and imidacloprid is widely used to preserve hemlock stands in the region (Turcotte et al. 2017). Imidacloprid applied to soil in forest systems can leach into surrounding aquatic habitats (Benton et al. 2016), and thus assessing potential impacts on aquatic and aquatic-stage amphibians is relevant in these systems. However, vulnerability may be 
highest for terrestrial amphibians that are chronically exposed to comparatively high concentrations of the pesticide in soil, particularly for amphibians occupying soil in imidacloprid drench or injection zones. Van Meter et al. (2014) confirmed that anurans can uptake imidacloprid through dermal exposure, but to our knowledge this has not been tested in terrestrial salamanders, and no studies have assessed sublethal effects of imidacloprid on salamanders.

The purpose of this study was to determine if exposure of salamanders to soil contaminated with high concentrations of imidacloprid results in uptake and bioaccumulation of the pesticide, and if detectable sublethal effects occur. We used terrestrial juvenile spotted salamanders (Ambystoma maculatum) as our focal species. We tested the influence of imidacloprid soil concentration and number of days of exposure (hereafter exposure time) on salamander bioaccumulation, body condition, and prey consumption to better understand how application concentration and chronic exposure could impact salamanders.

\section{MATERIALS AND METHODS}

\subsection{Salamander collection and husbandry}

We collected larval spotted salamanders on 1 July 2018 from 2 created vernal pools (distance between pools $=1.5 \mathrm{~km}$ ) in the Monongahela National Forest, West Virginia, USA, that were located ca. $12 \mathrm{~km}$ from the nearest hemlock stands treated with imidacloprid based on U.S. Forest Service records. We transferred the larvae to an indoor laboratory at West Virginia University, and maintained them in three 38-L aquatic tanks until metamorphosis. We separated larvae by size class to reduce cannibalism, and fed them blood worms ad libitum until metamorphosis. We placed floating islands in the aquatic tanks to minimize drowning of individuals undergoing metamorphosis. When salamanders lost their gills and tail fins (20 July 29 August), we transferred them to individual terrestrial tanks $(4.5 \mathrm{~cm} \mathrm{x} 7 \mathrm{~cm})$. We lined the terrestrial tanks with a moist paper towel and provided salamanders with an additional moist paper towel as a cover object. We fed terrestrial salamanders small crickets, earthworms, and waxworms ad libitum until initiation of the experiment on 31 October 2018. Mean weight at experiment initiation was $2.98 \mathrm{~g}$ (range $=1.49-4.23 \mathrm{~g}, \mathrm{~N}=49$ ). 


\subsection{Soils and pesticides}

We collected soil from an untreated eastern hemlock (Tsuga canadensis) stand in the West Virginia Botanic Garden, Morgantown, West Virginia. We restricted our collection to the organic layer because imidacloprid binds to organic matter in soil (Liu et al. 2006), and thus we would expect long-term persistence of the pesticide to be highest in this layer. During active periods, Ambystoma salamanders typically use subterranean refuges that are close to the surface

(Faccio 2003), providing the opportunity for chronic exposure to pesticides present in the organic layer. We autoclaved the soil at $121^{\circ} \mathrm{C}$ for 45 minutes to minimize microbial degradation of imidacloprid during the study (Sabourmoghaddam et al. 2015). We also neutralized the soil to ca. $\mathrm{pH} 7$ using sodium bicarbonate because previous research found that low $\mathrm{pH}(\leq 5)$ negatively impacted growth and survivorship of juvenile Marbled Salamanders (Ambystoma opacum; Anderson and Johnson 2018).

We used Merit ${ }^{\circledR} 75 \mathrm{WSP}$, a commercially available imidacloprid treatment that is commonly used by land management agencies for application in hemlock systems, including by the National Park Service in West Virginia (Strickler 2014). The product instructions recommend applying $0.75 \mathrm{~g}$ and $1.5 \mathrm{~g}$ of active ingredient per $2.54 \mathrm{~cm}$ trunk diameter at breast height for trees $<38.1 \mathrm{~cm}$ and $\geq 38.1 \mathrm{~cm}$ in diameter, respectively (Cowles 2009, Benton and Cowles 2017). The diameter of hemlock trees can exceed $100 \mathrm{~cm}$ (Godman and Lancaster 1990), and thus the amount of active ingredient (AI) used can exceed $60 \mathrm{~g}$ for very large trees. We tested two soil imidacloprid concentrations for this study, including 'moderate' and 'high' concentration treatments consisting of $0.15 \mathrm{~g}$ and $1 \mathrm{~g}$ of dissolved imidacloprid, respectively, mixed in $70 \mathrm{~g}$ of soil (i.e., 2,143,000 $\mathrm{ng} / \mathrm{mL}$ and 12,286,000 $\mathrm{ng} / \mathrm{mL}$, respectively). Once soil was treated with the imidacloprid, we minimized soil exposure to light to restrict photodegradation of imidacloprid prior to, and during, the experiment (Liu et al. 2006).

\subsection{Experimental design}

We reared 49 spotted salamanders for inclusion in the experiment, and began the experiment on 31 Oct 2018. We housed experimental salamanders in individual $4.5 \mathrm{~cm} \mathrm{x} 7 \mathrm{~cm}$ containers containing $70 \mathrm{~g}$ of soil and no cover object. We kept soil moist throughout the experiment by misting the soil with non-chlorinated $\mathrm{H}_{2} \mathrm{O}$. We randomly placed 42 of the salamanders into the 2 imidacloprid treatments and 7 exposure times, with 3 individuals used per 
treatment-exposure time combination. Exposure time included 1, 3, 6, 9, 12, 15, and 18 days of pesticide exposure. We used the remaining 7 salamanders as controls. We measured and weighed all salamanders at initiation of the experiment, and remeasured control salamanders at each exposure time to provide comparative data for body condition. We used a salamander stick to maximize accuracy of salamander length measurements (Margenau et al. 2018). We measured salamanders to the nearest $0.1 \mathrm{~mm}$ using dial calipers (Wiha Tools, Monticello, Minnesota, USA), and weighed salamanders to the nearest $1 \mathrm{mg}$ using a precision balance (Ohaus SPX123, Parsippany, New Jersey, USA). Every 3 days, we removed the remaining salamanders from experimental tanks for ca. 24 hours to allow them to feed on non-contaminated prey. During this time, we kept the salamanders in individual tanks lined with a moist paper towel and provided them with a single waxworm weighing ca. $0.2 \mathrm{~g}$. We recorded prey consumption by each salamander throughout the experiment.

\subsection{Salamander processing and pesticide extraction}

At the conclusion of each exposure time category, we placed salamanders assigned to that time in individual holding bags and euthanized them through exposure to carbon dioxide. We then handwashed each salamander under running tap water for two minutes to remove all soil and minimize presence of imidacloprid residue on the epidermis, and transferred salamanders to clean holding bags. We measured and weighed the salamanders, and then froze them until conclusion of the experiment and subsequent processing for imidacloprid extraction.

We quantified the concentration of imidacloprid in salamanders using ultra-performance liquid chromatography-tandem mass spectrometry ([UP] LC-MS/MS). Pesticide extraction and chromatographic and mass spectrometry conditions were adapted from procedures developed by Lehotay (2006) and Galeano et al. (2013). We placed salamanders in individual $50 \mathrm{ml}$ tubes, flash froze them in liquid nitrogen, and then placed them in a freeze dryer for 3 days. We placed $35-\mathrm{mm}$ steel beads into each $50 \mathrm{ml}$ tube and ground the salamanders in a Retsch MixerMill (MM 400, Haan, Germany) for 3 mins at $30 \mathrm{reps} / \mathrm{min}$. We then removed the steel beads and added $10 \mathrm{ml}$ of deionized water and $10 \mathrm{ml}$ of acetonitrile. Samples were briefly vortexed then sonicated for 20 mins at room temperature in a sonication bath. We added Quick Easy Cheap Effective Rugged Safe (QuEChERS) Mylar salt pouches (UCT, ECQUEU7-MP) to each sample, and the samples were vortexed for 10 secs and shaken by hand for $1 \mathrm{~min}$. We centrifuged the 
samples at 2,200 relative centrifugal force for 5 mins. We assembled a high-throughput vacuum apparatus with clean-up cartridges (UCT, ECPSAC1856) and conditioned with $5 \mathrm{~mL}$ of acetonitrile. Eight $\mathrm{ml}$ of the organic layer (acetonitrile) of each sample was collected and cleaned through the cartridges, and deposited in $15 \mathrm{ml}$ glass test tubes. We then dried the test tubes under nitrogen at $50{ }^{\circ} \mathrm{C}$, reconstituted them in $0.5 \mathrm{ml}$ of acetonitrile, and filtered the samples through PTFE Whatman Mini-UniPrep Syringeless Filter vials.

We used an Exion LC AD UHPLC system coupled with an AB Sciex Qtrap 5500 triple quadrupole AcQuRate CEM detector. We separated the compounds imidacloprid, imidaclopridurea, and imidacloprid-olefin, as well as external standards, on a Kromasil $\mathrm{C}_{-18}$ column (2.1 x 50 $\mathrm{mm}$ ) maintained at an oven temperature of $40{ }^{\circ} \mathrm{C}$ using a mobile phase gradient of (A) $0.1 \%$ formic acid in water and (B) $0.1 \%$ formic acid in acetonitrile. We programmed the elution gradient as follows: $0-1.0 \mathrm{~min}$, isocratic $\mathrm{A}$ to $\mathrm{B}(80: 20, \mathrm{v} / \mathrm{v}) ; 1.0-1.3 \mathrm{~min}$, from A to $\mathrm{B}(80: 20$, $\mathrm{v} / \mathrm{v})$ to $(0: 100, \mathrm{v} / \mathrm{v}) ; 1.3-2.3 \mathrm{~min}$, isocratic $\mathrm{A}$ to $\mathrm{B}(0: 100, \mathrm{v} / \mathrm{v})$; at $2.3 \mathrm{~min}$, from $\mathrm{A}$ to $\mathrm{B}(0: 100$, $\mathrm{v} / \mathrm{v})$ to $(80: 20, \mathrm{v} / \mathrm{v}) ; 2.3-6.0 \mathrm{~min}$, isocratic $\mathrm{A}$ to $\mathrm{B}(80: 20, \mathrm{v} / \mathrm{v})$. We maintained the autosampler temperature at $10^{\circ} \mathrm{C}$; the injection volume was $2 \mu 1$.

The LC-MS/MS detection of the compounds was performed by electrospray ionization (ESI) source operated in positive ion mode. We used multiple reaction monitoring (MRM) for the detection and quantification of imidacloprid and metabolites. MRM parameters were as follows: imidacloprid, Q1 mass 256.000 Da, Q3 mass 209.000 Da, 50.0 msec; imidacloprid-urea, Q1 mass 213.200 Da, Q3 mass 129.000 Da, 50.0 msec; imidacloprid-olefin, Q1 mass 254.100 Da, Q3 mass 171.000 Da, $50 \mathrm{msec}$. We maintained the IonSpray voltage and source temperature at $4.50 \mathrm{kV}$ and $450{ }^{\circ} \mathrm{C}$, respectively. We performed data acquisition and processing using the software Analyst ${ }^{\circledR}$ (Sciex, Version 1.6.3).

We assessed recovery of imidacloprid and metabolites from salamanders by spiking nonstudy salamander tissues with known concentrations of the chemicals. We used tissue from wildcaught dusky salamanders (Desmognathus spp.) that had been previously analyzed via LCMS/MS to confirm concentrations lower than $0.5 \mathrm{ng} / \mathrm{mL}$ for the targeted compounds. We homogenized a total of $10 \mathrm{~g}$ of salamander tissue in a mixer mill and used $0.5 \mathrm{~g}$ of the tissue for each spike. We conducted tissue spikes by adding $1 \mathrm{ml}$ of a mixed standard solution containing imidacloprid, imidacloprid-urea, and imidacloprid-olefin at 10,000 ng/mL, 1,000 ng/mL, and 100 
$\mathrm{ng} / \mathrm{mL}$ in acetonitrile. The average recovery of salamanders spiked with imidacloprid, imidacloprid-urea, and imidacloprid-olefin was $73.5 \%, 65.1 \%$, and $49.2 \%$, respectively.

\subsection{Statistical analyses}

We assessed and quantified the influence of soil imidacloprid concentration (control, moderate, high) and exposure time on salamander bioaccumulation, body condition, and prey consumption. We used concentration of imidacloprid in each salamander as the bioaccumulation response variable. We created a body condition index (BCI) by regressing (log) body length on (log) weight (Schulte-Hostedde et al. 2005). Positive residuals indicate a higher-than-average weight for a given length, and vice versa. For each salamander, we computed the difference in these residual values between the initial and end measurement and used this difference as our BCI. This allowed us to control for individual differences in body condition at initiation of the experiment without adding an additional model covariate. For prey consumption, we used a binary response variable that represented if prey was consumed each feeding day.

We used a generalized least squares model to assess soil imidacloprid concentration and exposure time effects on salamander bioaccumulation for the 42 individuals in the high and low treatments (Zuur et al. 2009). The body condition and prey consumption data sets included repeated measurements of the 49 individuals from all three treatments, and thus we used mixed effects models, treating individuals as an intercept random effect (Zuur et al. 2009). We used a Gaussian distribution for the bioaccumulation and body condition analyses, and a binomial distribution for the prey consumption analysis. We assessed model fit and determined the most appropriate model structures using residual plots and Akaike Information Criterion (AIC) scores (Zuur et al. 2009). For the body condition model, examination of residuals indicated that variance increased with increasing exposure time. To address this, we used a fixed variance structure based on exposure time, which provided a better model fit than a constant variance structure.

For each data set, we used a model selection approach with AIC corrected for small sample size $\left(\mathrm{AIC}_{c}\right)$ to determine the optimal fixed effect covariate structure (Burnham et al. 2011). Specifically, we compared interaction, additive, and main effects models to a null model that contained no fixed effects (Table 1). For the body condition and prey consumption model selections, all models included individuals as an intercept random effect. We performed all 
statistical analyses using program R (version 3.5.3; The R Foundation for Statistical Computing, Vienna, Austria). We used the package nlme (version 3.1-137) for the bioaccumulation and body condition analyses, package lme4 (version 1.1-21) for the prey consumption analysis, and package AICcmodavg (version 2.2-1) for model selection.

\section{RESULTS}

No imidacloprid, imidacloprid-olefin, or imidacloprid-urea was detected in the 7 control salamanders. Imidacloprid concentration in all treatment salamanders exceeded the limit of detection and quantification (1731 and $5770.1 \mathrm{ng} / \mathrm{mL}$, respectively). Mean salamander imidacloprid concentration in the moderate and high soil concentration groups was 18782.8 $\mathrm{ng} / \mathrm{mL}$ and $27562.4 \mathrm{ng} / \mathrm{mL}$, respectively (Figure 1a). The top model for imidacloprid bioaccumulation included an additive effect for soil concentration and exposure time (Akaike weight $=0.45$; Table 1$)$. Mean salamander imidacloprid concentration increased by $129.7( \pm$ 79.4) ng/mL per day. Salamander imidacloprid concentration per soil imidacloprid concentration and exposure time is shown in Figure 1b, c. All treatment salamanders contained detectable levels of imidacloprid-olefin and imidacloprid-urea. Mean concentration of imidacloprid-olefin was 1097.7 (range $=262-3282.1)$ and $2445($ range $=604-5002.6) \mathrm{ng} / \mathrm{mL}$ in the moderate and high soil concentration groups, respectively. Mean concentration of imidacloprid-urea was 260.5 $($ range $=77.4-713.8)$ and $523.7($ range $=198.7-1086.5) \mathrm{ng} / \mathrm{mL}$ in the moderate and high soil concentration groups, respectively.

The top model for salamander BCI included an interaction effect between soil imidacloprid concentration and exposure time (Akaike weight $=0.48$; Table 1). Predicted BCI had a minimal positive association with exposure time for control salamanders (slope $=$ 0.0003/exposure day; Figure 2a). Predicted BCI was negatively associated with exposure time for moderate and high soil concentration salamanders, with a ca. 3 times stronger relationship for high soil concentration salamanders (slope $=-0.0019$ vs $-0.0064 /$ exposure day for moderate and high soil concentration salamanders, respectively; Figure 2a).

The top model for prey consumption included an additive effect between soil imidacloprid concentration and exposure time (Akaike weight $=0.56$; Table 1 ). Probability of prey consumption at exposure day 3 was $0.989,0.724$, and 0.494 for control, moderate, and high soil concentration salamanders, respectively. At exposure day 15, probability of prey 
consumption declined to $0.669,0.383$, and 0.005 for control, moderate, and high soil concentration salamanders, respectively (Figure 2b). No high soil concentration salamander consumed prey after 9 days of imidacloprid exposure.

\section{DISCUSSION}

The results of this study indicate that terrestrial salamanders can uptake the pesticide imidacloprid through dermal exposure, consistent with the findings of Van Meter et al. (2014, 2015) for terrestrial anurans. We also found that while exposure to high imidacloprid soil concentrations did not result in mortality during the time-span of our study, it did negatively impact body condition, likely related to the decreased prey consumption rates that we also observed. However, we were unable to explicitly quantify the relationship between BCI and prey consumption because body condition was only measured at the beginning and end of the experiment, and the number of prey consumption events for most salamanders was too small to reliably estimate proportion of prey consumed. Amphibian body condition correlates with survival, productivity, and movement dynamics (e.g., Lowe et al. 2006, Reading 2007, Roznik et al. 2015) and these individual-level effects can scale up to impact population-level vital rates (Ozgul et al. 2010, Willson et al. 2012).

We recognize that the presence of very high imidacloprid concentrations in forest systems is limited to initial applications at soil drench and injection points, and these are both spatially and temporally limited. However, pesticide degradation can take years in forest soils with high organic matter content, such as hemlock systems (Anhalt et al. 2008, Bonmatin et al. 2015). Terrestrial salamanders have long life-spans and generally have restricted movement outside of the breeding period (reviewed by Petranka et al. 1998), and thus could be exposed to lower concentrations of imidacloprid in the environment for many years and potentially their entire lifespan. In addition, lower concentrations of imidacloprid can be present in the broader environment, primarily through deposition and movement of tree needles or leaves containing the pesticide (Cowles et al. 2006), and leaching of the pesticide into groundwater and subsequent transport to streams (Benton et al. 2016).

Our study examined bioaccumulation strictly through dermal uptake. Salamanders in the wild could also acquire imidacloprid through consumption of contaminated invertebrate prey (Pisa et al. 2015). Further, predators of salamanders, including mammals, birds, reptiles, other 
amphibians, fish, and macroinvertebrates (Petranka 1998), could potentially acquire the chemical through consumption of contaminated salamanders. Additional research is needed to assess potential impacts to salamanders and other vertebrates from chronic exposure to low pesticide concentrations in forest systems, as well as to assess the potential for bioaccumulation of imidacloprid through prey consumption.

Eastern hemlock is a foundation species in both urban and forested landscapes of the eastern United States because it creates critical and stable conditions required by many species (Ellison 2014). Many plants and animals that depend on hemlock systems would be negatively impacted by extensive mortality of hemlock forests, thus, control of hemlock woolly adelgid is critical. However, our laboratory study confirms that imidacloprid can have measurable sublethal effects on salamanders, at least at high concentrations. Additional research is needed to assess both individual-level and population-level impacts to salamanders in real-world systems.

\section{ACKNOWLEDGMENTS}

Funding for this study was supported by the U.S. Geological Survey-National Park Service Water Quality Partnership Program, Foundation for the Conservation of Salamanders, West Virginia University Program to Stimulate Competitive Research, and U.S. Forest Service Northern Research Station. Donald Brown was supported by the USDA National Institute of Food and Agriculture, McIntire Stennis project WVA00122, and the West Virginia Agricultural and Forestry Experiment Station. We thank the U.S. Forest Service for access and permission to collect wild salamander larvae. We thank Alice Millikin, Yvette Halley, Eliana Henriquez, Lacy Rucker, and Carl Jacobsen for assistance with salamander collection and husbandry. We thank Terry McManus for imidacloprid extraction guidance and assistance. Capture and handling methods were approved by the West Virginia Division of Natural Resources (Permit \#2018.105) and West Virginia University Institutional Animal Care Use Committee (Protocol \#1804013867). Any use of trade, product, or firm names is for descriptive purposes only and does not imply endorsement by the U.S. Government.

\section{LITERATURE CITED}

Anderson, K.J., Johnson, J.R. 2018. The effects of substrate $\mathrm{pH}$ on growth and survival of recently metamorphosed marbled salamanders (Ambystoma opacum). Herpetological Conservation and Biology, 13(1): 70-79. 
Anhalt, J.C., Moorman, T.B., Koskinen, W.C. 2008. Degradation and sorption of imidacloprid in dissimilar surface and subsurface soils. Journal of Environmental Science and Health Part B, 43(3): 207-213.

Benton, E.P., Cowles, R.S. 2017. Optimized insectide dosage for hemlock woolly adelgid control in hemlock trees. University of Georgia, Warnell School of Forestry and Natural Resources Outreach Report WSFNR-17-01, Tifton, Georgia, USA.

Benton, E.P., Grant, J.F., Mueller, T.C., Webster, R.J., Nichols, R.J. 2016. Consequences of imidacloprid treatments for hemlock woolly adelgid on stream water quality in the southern Appalachians. Forest Ecology and Management, 360(2016): 152-158.

Bonmatin, J.-M., Giorio, C., Girolami, V., Goulson, D., Kreutzweiser, D.P., Krupke, C., Liess, M., Long, E., Marzaro, M., Mitchell, E.A.D., Noome, D.A., Simon-Delso, N., Tapparo, A. 2015. Environmental fate and exposure; neonicotinoids and fipronil. Environmental Science and Pollution Research, 22(1): 35-67.

Buckley, L.B., Jetz, W. 2007. Environmental and historical constraints on global patterns of amphibian richness. Proceedings of the Royal Society B: Biological Sciences, 274(1614): 1167-1173.

Burnham, K.P., Anderson, D.R., Huyvaert, K.P. 2011. AIC model selection and multimodel inference in behavioral ecology: some background, observations, and comparisons. Behavioral Ecology and Sociobiology, 65(1): 23-35.

Cowles, R.S. 2009. Optimizing dosage and preventing leaching of imidacloprid for management of hemlock woolly adelgid in forests. Forest Ecology and Management, 257(3): 10261033.

Cowles, R.S., Lagalante, A.F. 2009. Activity and persistence of systemic insecticides for managing hemlock woolly adelgids. Pages 17-18 in K. A. McManus and K. W. Gottschalk, editors. Proceedings of the $20^{\text {th }}$ U.S. Department of Agriculture interagency research forum on invasive species. U.S. Forest Service Northern Research Station General Technical Report NRS-P-51, Newtown Square, Pennsylvania, USA.

Cowles, R.S., Montgomery, M.E., Cheah, C.A.S.-J. 2006. Activity and residues of imidacloprid applied to soil and tree trunks to control hemlock woolly adelgid (Hemiptera: Adelgidae) in forests. Journal of Economic Entomology, 99(4): 1258-1267.

Dilling, C., Lambdin, P., Grant, J., Rhea, R. 2010. Spatial and temporal distribution of imidacloprid in eastern hemlock in the southern Appalachians. Journal of Economic Entomology, 103(2): 368-373.

Ellison, A.M. 2014. Experiments are revealing a foundation species: a case study of eastern hemlock (Tsuga canadensis). Advances in Ecology 2014:Article ID 456904.

Faccio, S.D. 2003. Postbreeding emigration and habitat use by Jefferson and spotted salamanders in Vermont. Journal of Herpetology, 37(3): 479-489.

Feng, S., Kong, Z., Wang, X., Zhao, L., Peng, P. 2004. Acute toxicity and genotoxicity of two novel pesticides on amphibian, Rana N. Hallowell. Chemosphere, 56(5): 457-463. 
Galeano, M.P., Scordino, M., Sabatino, L., Pantò, V., Morabito, G., Chiappara, E., Traulo, P., Gagliano, G. 2013. UHPLC/MS-MS analysis of six neonicotinoids in honey by modified QuEChERS: method development, validation, and uncertainty measurement. International Journal of Food Science 2013:863904.

Gibbons, D., Morrissey, C., Mineau, P. 2015. A review of the direct and indirect effects of neonicotinoids and fipronil on vertebrate wildlife. Environmental Science and Pollution Research, 22(1): 103-118.

Godman, R.M., Lancaster, K. 1990. Tsuga canadensis (L.) Carr. Eastern hemlock. Pages 604612 in R. M. Burns and B. H. Honkala, editors. Silvics of North America: 1. Conifers. U.S. Forest Service Agricultural Handbook 654, Washington, D.C., USA.

Hallmann, C.A., Foppen, R.P.B., van Turnhout, C.A.M., de Kroon, H., Jongejans, E. 2014. Declines in insectivorous birds are associated with high neonicotinoid concentrations. Nature, 511(7059): 341-344.

Jeschke, P., Nauen, R. 2008. Neonicotinoids - from zero to hero in insecticide chemistry. Pest Management Science, 64(11): 1084-1098.

Jeschke, P., Nauen, R., Schindler, M., Elbert, A. 2011. Overview of the status and global strategy for neonicotinoids. Journal of Agricultural and Food Chemistry, 59(7): 2897-2908.

Kovacs, K.F., Haight, R.G., McCullough, D.G., Mercader, R.J., Siegert, N.W., Liebhold, A.M. 2010. Cost of potential emerald ash borer damage in U.S. communities, 2009-2019. Ecological Economics, 69(3): 569-578.

Lamb, A.B., Salom, S.M., Kok, L.T., Mausel, D.L. 2006. Confined field release of Laricobius nigrinus (Coleoptera: Derodontidae), a predator of the hemlock woolly adelgid, Adelges tsugae (Hemiptera: Adelgidae), in Virginia. Canadian Journal of Forest Research, 36(2): 369-375.

Lehotay, S. 2006. Quick, easy, cheap, effective, rugged, and safe approach for determining pesticide residues. Pages 239-261 in J. L. Martínez Vidal and A. Garrido Frenich, editors. Pesticide protocols, Humana Press, New York, New York, USA.

Liu, W., Zheng, W., Ma, Y., Liu, K. 2006. Sorption and degradation of imidacloprid in soil and water. Journal of Environmental Science and Health Part B: Pesticides, Food Contaminants, and Agricultural Wastes, 41(5): 623-634.

Lopez-Antia, A., Ortiz-Santaliestra, M.E., Mougeot, F., Mateo, R. 2013. Experimental exposure of red-legged partridges (Alectoris rufa) to seeds coated with imidacloprid, thiram and difenoconazole. Ecotoxicology, 22(1): 125-138.

Lovett, G.M., Weiss, M., Liebhold, A.M., Holmes, T.P., Leung, B., Lambert, K.F., Orwig, D.A., Campbell, F.T., Rosenthal, J., McCullough, D.G., Wildova, R., Ayres, M.P., Canham, C.D., Foster, D.R., LaDeau, S.L., Weldy, T. 2016. Nonnative forest insects and pathogens in the United States: impacts and policy options. Ecological Applications, 26(5): 1437-1455.

Lowe, W.H., Likens, G.E., Cosentino, B.J. 2006. Self-organization in streams: the relationship between movement behaviour and body condition in a headwater salamander. Freshwater Biology, 51(11): 2052-2062. 
Margenau, E.L., Crayton, S.M., Rucker, L.E., Jacobsen, C.D., Brown, D.J. 2018. Modified salamander stick to facilitate accurate measurement of small individuals. Herpetological Review, 49(2): 243-246.

Meng, P.S., Hoover, K., Keena, M.A. 2015. Asian longhorned beetle (Coleoptera:

Cerambycidae), an introduced pest of maple and other hardwood trees in North America and Europe. Journal of Integrated Pest Management, 6(1): 4.

Muzika, R.M. 2017. Opportunities for silviculture in management and restoration of forests affected by invasive species. Biological Invasions, 19(11): 3419-3435.

Ozgul, A., Childs, D.Z., Oli, M.K., Armitage, K.B., Blumstein, D.T., Olson, L.E., Tuljapurkar, S., Coulson, T. 2010. Coupled dynamics of body mass and population growth in response to envrionmental change. Nature, 466(7305): 482-485.

Pérez-Iglesias, J.M., Ruiz de Arcaute, C., Nikoloff, N., Dury, L., Soloneski, S., Natale, G.S., Larramendy, M.L. 2014. The genotoxic effects of the imidacloprid-based insecticide formulation Glacoxan Imida on Montevideo tree frog Hypsiboas pulchellus tadpoles (Anura, Hylidae). Ecotoxicology and Environmental Safety, 104(2014): 120-126.

Petranka, J.W. 1998. Salamanders of the United States and Canada. Smithsonian Books, Washington, D.C., USA.

Pisa, L.W., Amaral-Rogers, V., Belzunces, L.P., Bonmatin, J.M., Downs, C.A., Goulson, D., Kreutzweiser, D.P., Krupke, C., Liess, M., McField, M., Morrissey, C.A., Noome, D.A. Settele, J., Simon-Delso, N., Stark, J.D., Van der Sluijs, J.P., Van Dyck, H., Wiemers, M. 2015. Effects of neonicotinoids and fipronil on non-target invertebrates. Environmental Science and Pollution Research, 22(1): 68-102.

Reading, C.J. 2007. Linking global warming to amphibian declines through its effects on female body condition and survivorship. Oecologia, 151(1): 125-131.

Rissler, L.J., Smith, W.H. 2010. Mapping amphibian contact zones and phylogeographical break hotspots across the United States. Molecular Ecology, 19(24): 5404-5416.

Rogers, K.H., McMillin, S., Olstad, K.J., Poppenga, R.H. 2019. Imidacloprid poisoning of songbirds following a drench application of trees in a residential neighborhood in California, USA. Environmental Toxicology, Early View.

Roznik, E.A., Sapsford, S.J., Pike, D.A., Schwarzkopf, L., Alford, R.A. 2015. Conditiondependent reproductive effort in frogs infected by a widespread pathogen. Proceedings of the Royal Society B: Biological Sciences, 282(1810): 20150694.

Ruiz de Arcaute, C., Pérez-Iglesias, J.M., Nikoloff, N., Natale, G.S., Soloneski, S., Larramendy, M.L. 2014. Genotoxicity evaluation of the insecticide imidacloprid on circulating blood cells of Montevideo tree frog Hypsiboas pulchellus tadpoles (Anura, Hylidae) by comet and micronucleus bioassays. Ecological Indicators, 45(2014): 632-639.

Sabourmoghaddam, N., Zakaria, M.P., Omar, D. 2015. Evidence for the microbial degradation of imidacloprid in soils of Cameron Highlands. Journal of the Saudi Society of Agricultural Sciences, 14(2): 182-188.

Schulte-Hostedde, A.I., Zinner, B., Millar, J.S., Hickling, G.J. 2005. Restitution of mass-size residuals: validating body condition indices. Ecology, 86(1): 155-163. 
Simon-Delso, N., Amaral-Rogers, V., Belzunces, L.P., Bonmatin, J.M., Chagnon, M., Downs, C., Furlan, L., Gibbons, D.W., Giorio, C., Girolami, V., Goulson, D., Kreutzweiser, D.P., Krupke, C.H., Liess, M., Long, E., Mcfield, M., Mineau, P., Mitchell, E.A., Morrissey, C.A., Noome, D.A., Pisa, L., Settele, J., Stark, J.D., Tapparo, A., Van Dyck, H., Van Praagh, J., Van Der Sluijs, J.P., Whitehorn, P.R., Wiemers, M. 2015. Systemic insecticides (neonicotinoids and fipronil): trends, uses, mode of action and metabolites. Environmental Science and Pollution Research, 22(1): 5-34.

Strickler, L.K. 2014. Hemlock woolly adelgid control project annual report 2012: New River Gorge National River, Gauley River National Recreation Area, and Bluestone National Scenic River. National Park Service Natural Resource Report NPS/NERI/NRR2014/818, Fort Collins, Colorado, USA.

Turcotte, R.M., Lagalante, A., Jones, J., Cook, F., Elliott, T., Billings, A.A., Park, Y.L. 2017. Spatial and temporal distribution of imidacloprid within the crown of eastern hemlock. Journal of Insect Science, 17(1): Article 22.

Van Meter, R.J., Glinski, D.A., Hong, T., Cyterski, M., Henderson, W.M., Purucker, S.T. 2014. Estimating terrestrial amphibian pesticide body burden through dermal exposure. Environmental Pollution, 193(2014): 262-268.

Van Meter, R.J., Glinski, D.A., Henderson, W.M., Garrison, A.W., Cyterski, M., Purucker, S.T. 2015. Pesticide uptake across the amphibian dermis through soil and overspray exposures. Archives of Environmental Contamination and Toxicology, 69(4): 545-556.

Wang, X., Anadón, A., Wu, Q., Qiao, F., Ares, I., Martínez-Larrañaga, M-R., Yuan, Z., Martínez, M-A. 2018. Mechanism of neonicotinoid toxicity: impact on oxidative stress and metabolism. Annual Review of Pharmacology and Toxicology, 58(2018): 471-507.

Webb, B.R.E., Frank, J.R., Raupp, M.J. 2003. Eastern hemlock recovery from hemlock woolly adelgid damage following imidacloprid therapy. Journal of Arboriculture, 29(5): 298302.

Willson, J.D., Hopkins, W.A., Bergeron, C.M., Todd, B.D. 2012. Making leaps in amphibian ecotoxicology: translating individual-level effects of contaminants to population viability. Ecological Applications, 22(6): 1791-1802.

Zuur, A.F., Ieno, E.N., Walker, N.J., Saveliev, A.A., Smith, G.M. 2009. Mixed effects models and extensions in ecology with R. Springer, New York, New York, USA. 
Table 1. Model selection results to determine the optimal covariate structure for the influence of imidacloprid soil concentration (control [body condition and prey consumption-only], moderate, high) and time of exposure on terrestrial juvenile spotted salamander (Ambystoma maculatum) pesticide bioaccumulation ( $\mathrm{N}=42$ individuals and observations), body condition ( $\mathrm{N}=49$ individuals and 91 total observations), and prey consumption ( $\mathrm{N}=49$ individuals and 125 total observations), using Akaike's Information Criterion corrected for small sample size $\left(\mathrm{AIC}_{c}\right)$. The null model includes no fixed effects and is shown as (.). For the body condition and prey consumption model selections, all models included individuals as an intercept random effect. $w_{i}$ represents Akaike weights.

\begin{tabular}{|l|l|r|r|r|}
\hline Data Set & Model & Parameters & $\Delta \mathbf{A I C}_{\boldsymbol{c}}$ & $\boldsymbol{w}_{\boldsymbol{i}}$ \\
\hline Bioaccumulation & Concentration + Exposure & \multicolumn{1}{|c|}{4} & 0.00 & 0.45 \\
\hline & Concentration & 3 & 0.33 & 0.38 \\
\hline & Concentration x Exposure & 5 & 2.04 & 0.16 \\
\hline & $()$. & 2 & 46.71 & 0.00 \\
\hline & Exposure & 3 & 48.18 & 0.00 \\
\hline & & & & \\
\hline Body condition & Concentration x Exposure & 8 & 0.00 & 0.48 \\
\hline & Exposure & 4 & 1.42 & 0.23 \\
\hline & $()$. & 3 & 1.50 & 0.23 \\
\hline & Concentration & 5 & 5.26 & 0.03 \\
\hline & Concentration + Exposure & 6 & 5.46 & 0.03 \\
\hline & & & & \\
\hline Prey consumption & Concentration + Exposure & 5 & 0.00 & 0.56 \\
\hline & Concentration x Exposure & 7 & 0.52 & 0.43 \\
\hline & Exposure & 3 & 10.08 & 0.00 \\
\hline & Concentration & 4 & 10.22 & 0.00 \\
\hline & (.) & 2 & 16.25 & 0.00 \\
\hline
\end{tabular}



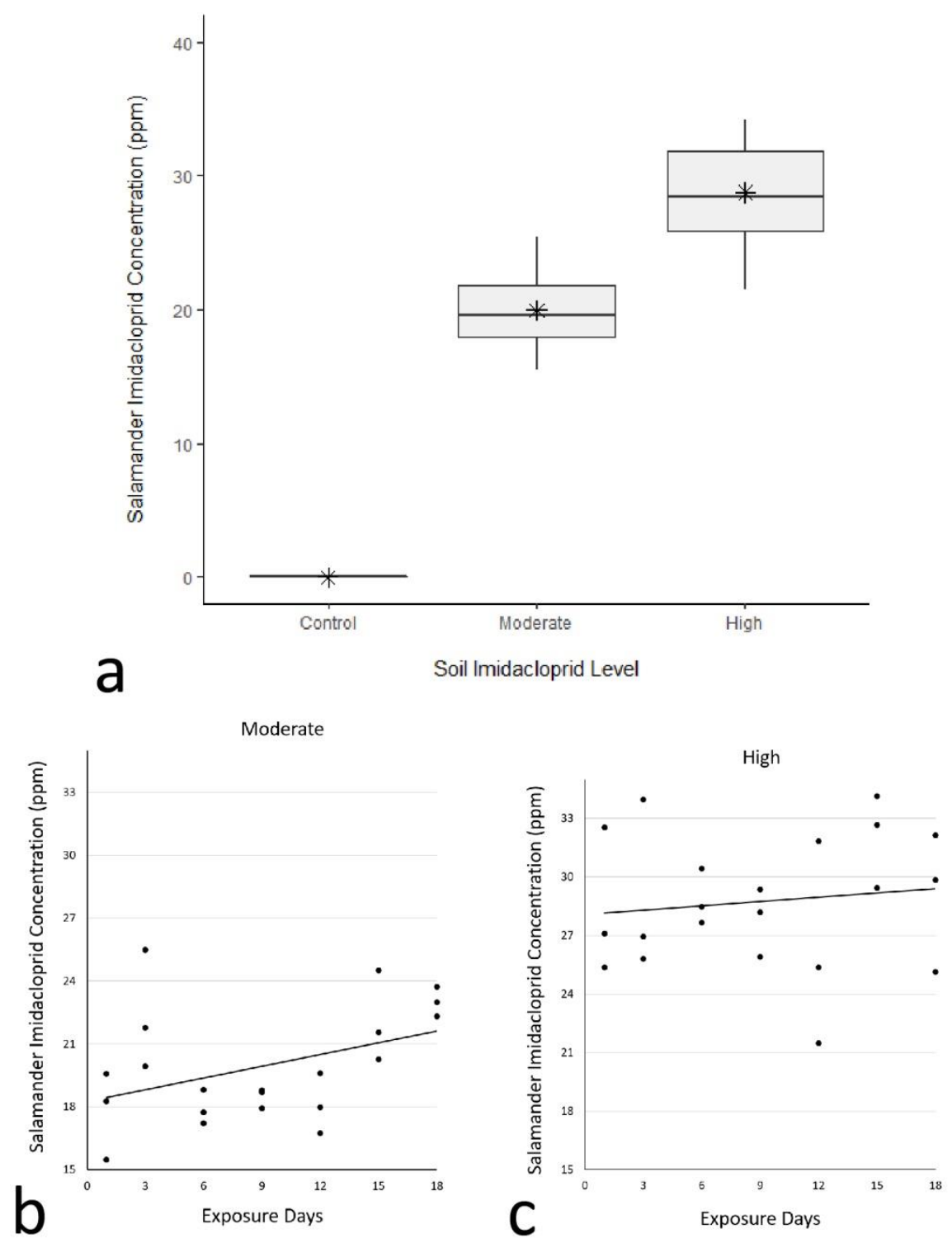

Figure 1. Spotted salamander (Ambystoma maculatum) imidacloprid concentrations for 3 soil imidacloprid treatment levels (control, moderate, high) and days of exposure (1-18). (a) Boxplot summaries of concentrations per treatment. Relationship between salamander imidacloprid concentration and number of days of exposure to moderate (b) and high (c) treatment levels of imidacloprid in soil. Dots represent individual salamander values, and lines represent a least squares line of best fit. 

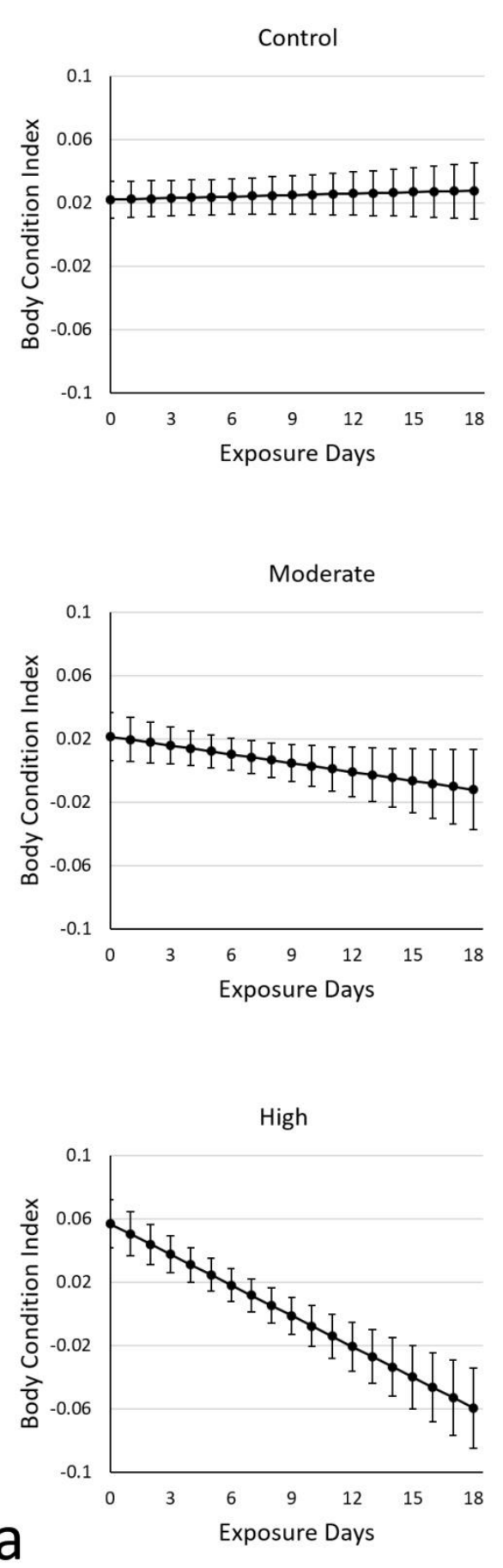
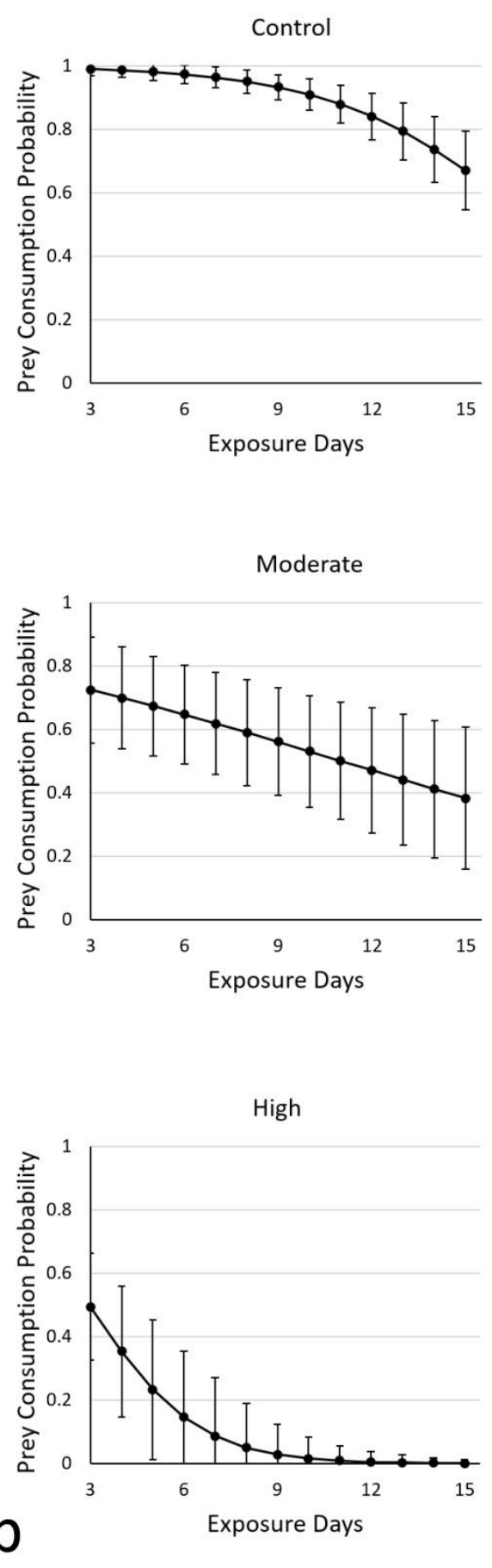

Figure 2. Model-predicted influence of soil imidacloprid concentration (control, moderate, high) and time of exposure (exposure days) on (a) body condition index and (b) prey consumption of terrestrial juvenile spotted salamanders (Ambystoma maculatum). Bars represent model standard errors. 


\title{
CHAPTER 3: EFFECTS OF IMIDACLOPRID EXPOSURE ON STREAM SALAMANDER ABUNDANCES
}

\begin{abstract}
Amphibians are declining globally due to anthropogenic changes in the environment, including exposure to chemical contaminants. Imidacloprid is a neonicotinic pesticide that is used worldwide and is the most effective method of mitigating hemlock tree loss from the invasive hemlock woolly adelgid. Although neonicotinoids are considered generally safe for vertebrates, imidacloprid has been found to decrease survival and have genotoxic effects on anurans. Research on the potential effects of imidacloprid exposure on salamanders is lacking. In this study, we assessed whether imidacloprid exposure affects stream salamander abundances. We surveyed stream salamanders 5-7 times at 48 study sites, 26 of which had been exposed to imidacloprid treatments. We used $N$-mixture models and a model selection approach to identify important predictors of salamander abundance and detection probability $(p)$ for adult Desmognathus fuscus, adult D. monticola, adult D. ochrophaeus, adult Eurycea spp., and Gyrinophilus porphyriticus larvae. We first selected the most parsimonious detection $(p)$ submodels and habitat variables, and then individually tested and ranked four predictors of imidacloprid exposure: imidacloprid water concentration $(\mathrm{ng} / \mathrm{mL})$, number of imidacloprid applications, presence/absence of treated trees, and presence/absence of environmental imidacloprid. There was support for models containing predictors of imidacloprid exposure for all species. Our results suggest that Desmognathus spp. abundances may be negatively affected by HWA treatments, particularly number of imidacloprid applications and presence of treated trees. However, we did not detect negative effects of imidacloprid exposure on Eurycea spp. or G. porphyriticus.
\end{abstract}

\section{INTRODUCTION}

Amphibians are currently facing a global conservation crisis with nearly half of amphibian populations in decline (Houlahan et al. 2000, Stuart et al. 2004). Many of these declines have been directly linked to anthropogenic changes, including exposure to chemical contaminants from human activities (Davidson 2004, Davidson and Knapp 2007, Sparling et al. 2001). Amphibians tend to be more vulnerable to chemical contamination than birds or mammals 
due to amphibian skin being highly permeable because respiration and regulation of water and ions occurs dermally, thereby providing a route of entry for contaminants into amphibian tissues (Quaranta et al. 2009). Additionally, most amphibian species use both aquatic and terrestrial environments and are therefore exposed to contamination in both (Brühl et al. 2011). Most research on the effects of chemical contaminants on amphibians has focused on physiological effects, such as reductions in body size, growth rate, body condition, and development (Gabor et al. 2018, Larson et al. 1998, Relyea and Diecks 2008).

Imidacloprid is a neonicotinoid insecticide that is a common and effective treatment to protect eastern hemlock (Tsuga canadensis) and Carolina hemlock (T. caroliniana) trees from the non-native invasive pest, hemlock woolly adelgid (HWA; Adelges tsugae; Havill et al. 2014). Hemlocks have a large geographical distribution across the eastern United States and provide important habitat for diverse invertebrate and vertebrate species (Becker et al. 2008, Ellison 2014, Havill et al. 2014, Snyder et al. 2002, Tingley et al. 2002). HWA has spread to ca. 50\% of hemlock's geographical range and has caused wide-spread declines in hemlock populations, necessitating chemical mitigation (Havill et al. 2014, Orwig et al. 2008).

Previous studies have documented imidacloprid leaching from HWA treatment areas and being detected in adjacent streams (Benton et al. 2016, Churchel et al. 2011, Wiggins et al. 2018). Its high water solubility allows for leaching into groundwater and streams (US EPA 2003), while its low volatility and a low soil adsorption coefficient makes it highly mobile in soil with low organic matter (Ding et al. 2011, Liu et al. 2002). These characteristics, in conjunction with the general proximity of hemlock forests to riparian areas, increase the risk of imidacloprid leaching into stream systems (Ding et al. 2011). Although imidacloprid begins to break down quickly in surface water when exposed to sunlight, continual leaching may maintain imidacloprid presence in stream systems near treated hemlocks (Benton et al. 2016, Wamhoff and Schneider, 1999).

Neonicotinoids are commonly considered to be non-harmful to vertebrates because they are highly selective for insect nicotinic acetylcholine receptors (nAChR), but concern has been expressed about non-target impacts of these pesticides (Hallman et al. 2014, Matsuda et al. 2001). A variety of sublethal effects of imidacloprid on mammals, birds, fish, and frogs, including impacts on reproduction and growth, have been identified (reviewed by Gibbons et al. 2015). The proximity of stream salamanders to HWA treatments, sensitivity of salamanders to 
chemical contaminants, and the global decline of amphibians all necessitate research investigating potential impacts of imidacloprid exposure on salamanders (Brühl et al. 2011, Stuart et al. 2004). Research on neonicotinoids and salamanders is lacking, but research on the effects of imidacloprid exposure on amphibians has been conducted on anurans (e.g. Ade et al. 2010, Pérez-Iglesias et al. 2014). Several studies have documented physiological changes in anurans from imidacloprid exposure. Feng et al. (2004) demonstrated that imidacloprid is genotoxic to the black-spotted pond frog (Pelophylax nigromaculatus) with DNA damage increasing as aquatic concentrations increased. Similarly, imidacloprid exposure led to DNA lesions in Montevideo tree frog (Hypsiboas pulchellus) tadpoles, although this effect was only displayed at concentrations higher than typical field conditions (Pérez-Iglesias et al. 2014). Imidacloprid exposure also decreased survival rates in northern cricket frogs (Acris crepitans; Ade et al. 2010).

North America is a global hotspot for salamander diversity (Yap et al. 2015), and salamanders are particularly abundant in the Appalachian Mountains (Petranka and Murray 2001). In headwater streams, salamanders are often the dominant vertebrates in terms of abundance and biomass (Burton and Likens 1975, Davic and Welsh 2004). Loss of salamander populations from headwater streams can have ecosystem-wide consequences because salamanders can influence insect population dynamics, regulate detritus food webs, and link stream and terrestrial food webs (Petranka 1998). Thus, salamander occupancy and abundance can serve as an indicator of stream quality (Southerland et al. 2004) and ecosystem stress (Lowe and Bolger 2002, Welsh and Ollivier 1998, Wood and Williams 2013).

The purpose of this study was to assess whether abundances of adult and larval salamanders are associated with stream water imidacloprid concentrations, the presence of imidacloprid or its metabolites in the environment, the presence of treated trees, or the number of imidacloprid applications adjacent to a stream. We hypothesized that salamander abundances would be lower in streams exposed to imidacloprid and would have a negative relationship with water imidacloprid concentration and number of imidacloprid applications. 


\section{METHODS}

\subsection{Study Sites}

This study was conducted in the Monongahela National Forest (MNF) and two units of the National Park Service (NPS): Gauley River National Recreational Area (GARI) and New River Gorge National River (NERI) in West Virginia, USA (Fig. 1-1). Hemlock trees in the MNF were treated with a single application of imidacloprid in 2014 or 2015 . Hemlock stand treatments in NPS units began in 2006 and have continued annually, including multiple applications (2-7 times) at 10 of the sampling locations (Table 1-1). We did not select NPS treatment sites if the last treatment occurred prior to 2011. We used ArcGIS 10.4 to identify candidate streams based on proximity to HWA treatments. Candidate streams were visited to determine whether the stream depth, stream substrate, and water flow speeds were suitable for sampling salamanders and stream invertebrates. Additionally, we selected small streams that generally did not have fish. Final study sites were selected based on the suitability of the streams for sampling, the proximity of treated trees, or the absence of treatments for non-impacted sites. Sites adjacent to HWA treatments had on average $306 \pm 158.7$ occurrences of imidacloprid applications (range $=$ 5-3993 applications), with applications representing individual tree treatments.

We sampled headwater streams for stream salamanders in 24 sites in MNF, 14 sites in NERI, and ten sites in GARI. Of these 48 sites, 26 were directly adjacent to HWA treatments and 22 were not adjacent to HWA treatments. Sites that were not adjacent to HWA treatments were either a minimum of $100 \mathrm{~m}$ upstream of imidacloprid application or were in a watershed without known HWA treatments. We selected $100 \mathrm{~m}$ as a minimum distance because Benton et al. (2015) did not detect imidacloprid in stream sites that were 10-100 m upstream of treated trees, and because stream salamanders typically have home ranges smaller than $100 \mathrm{~m}$ (reviewed by Petranka 1998).

\subsection{Water and Sediment Imidacloprid Extraction and Quantification}

See thesis chapter 2, sections 2.2 and 2.3 for water and sediment sampling, imidacloprid extraction, and imidacloprid quantification methods. 


\subsection{Salamander Sampling}

Within each of the 48 sites, we established three $3.3 \times 2 \mathrm{~m}$ subplots for a total plot area of $10 \times 2 \mathrm{~m}$. One $\mathrm{m}$ of the subplot width was on the bank and one $\mathrm{m}$ was within the wetted stream channel (Appendix 3-1). We primarily placed subplots in riffles $(\mathrm{n}=123)$, but placed subplots in runs $(\mathrm{n}=13)$ or pools $(\mathrm{n}=8)$ if the site did not have riffle habitat. We chose subplots that were similar in terms of stream depth, substrate, canopy cover, vegetative community, and flow regime. We completed salamander sampling in the NPS sites between April and July of 2017 and in the MNF sites between April and July of 2018, sampling each site 6-7 times during the year. We conducted surveys only during baseflow conditions. While moving upstream to prevent stream sediment from flowing downstream and obscuring our view, we flipped every cover object greater than $50 \mathrm{~mm}$ in diameter and searched through leaf packs. We recorded the number of cover objects flipped while sampling.

We removed all captured salamanders and placed them in plastic bags. We identified all salamanders to species, or genus when identification to species was not possible. After processing, we returned salamanders to their point of capture. We noted the genus or species of any escaped salamanders when possible. We considered Eurycea spp. and Gyrinophilus porphyriticus with gills to be juveniles. We also classified Desmognathus monticola $<18 \mathrm{~mm}$, D. fuscus $<15 \mathrm{~mm}$, and D. ochrophaeus $<12 \mathrm{~mm}$ to be juveniles (Bruce 1989, Danstedt 1975, Tilley 1980). When possible, we recorded whether escaped salamanders were juveniles or adults.

\subsection{Habitat variables measured}

At each subplot during salamander sampling, we measured air temperature $\left({ }^{\circ} \mathrm{C}\right)$ and relative humidity with a weather meter (Kestrel 3000, Kestrel Instruments, Boothwyn, Pennsylvania). After every sampling event, we measured stream depth $(\mathrm{cm})$ in the center of the plot. After most sampling events (5-6/year), we measured total dissolved solids ( $\mathrm{g} / \mathrm{L}$ ), water temperature $\left({ }^{\circ} \mathrm{C}\right)$, and $\mathrm{pH}$ at each subplot using a low range $\mathrm{pH} /$ conductivity/TDS tester (HI98129, Hanna Instruments, Woonsocket, Rhode Island). We measured canopy cover at each subplot once during each sampling season using a $25 \mathrm{~cm}$ x $25 \mathrm{~cm}$ plexiglass grid which was divided into $5 \mathrm{~cm} \times 5 \mathrm{~cm}$ cells. We held the plexiglass grid overhead and visually estimated how many cells were covered by the tree canopy and calculated \% canopy cover (Haché et al. 2013). We averaged the canopy cover measurements from the three subplots. Additionally, we 
estimated live hemlock basal area per hectare using a prism with a basal area factor of 10 . At each subplot, we sited trees through the prism to determine whether they should be tallied or tallied as borderline. Borderline trees were counted as a half of a tree. We calculated basal area

per hectare by dividing the total tree tally by the number of sampling points (3) and multiplying by the basal area factor (10). Once per season, we also visually estimated what percentage of the stream portion of the subplots was cover by cobble $(5-256 \mathrm{~mm})$ or boulders $(>256 \mathrm{~mm})$. We added $\%$ cobble and $\%$ boulder together to assess what percentage of the subplots were rocky cover, and averaged across the three subplots.

\subsection{Benthic surveys}

During May - June 2017 and May - July 2018, we sampled macroinvertebrates at three $0.3 \times 2 \mathrm{~m}$ subplots within each stream site so that total area sampled per stream was $0.3 \times 6 \mathrm{~m}$. We collected the samples adjacent to salamander sampling plots. We collected the samples in riffles $(n=128)$, except in several instances where riffles were not present. In these instances, we collected samples in runs $(n=12)$ or pools $(n=1)$. We placed a $0.3 \mathrm{~m}$ wide $\mathrm{D}$-net flush with the bottom of the stream and disturbed the substrate upstream of the D-net for 30 seconds. We only sampled sites in base flow conditions. We composited the three samples from each stream site into one sample and stored the invertebrates in $75 \%$ ethanol. All organisms in each sample were counted and body length of each was measured to the nearest mm using a millimeter grid placed underneath a dissecting microscope (Carl Zeiss Microscope, Thornwood, New York). We estimated macroinvertebrate biomass by using the length of each individual and length-weight equations found in the literature (e.g., Benke et al. 1990; Sabo et al. 2002) and summed the biomass estimates to obtain total biomass for each site.

\subsection{Statistical Methods}

We used single-season $N$-mixture models and a model selection approach to determine influential predictors of salamander abundance (Kéry and Royle, 2016). $\mathrm{N}$-mixture models use both spatial and temporal replication of count data to jointly estimate abundance and detection probability $(p)$, and thus they account for observed numbers being a product of both ecological and observational processes (Royle, 2004). We separated species capture datasets into adults and juveniles because we would expect individual-level detection probability to differ between the 
two groups. We estimated abundance for Desmognathus fuscus adults, D. monticola adults, D. ochrophaeus adults, Eurycea spp. adults, and G. porphyriticus juveniles. We excluded juveniles D. fuscus, D. monticola, and D. ochrophaeus and adult G. porphyriticus due to low sample sizes, and excluded Eurycea spp. juveniles due to high overdispersion (c-hat > 4).

For each abundance submodel, we tested Poisson, Zero-Inflated Poisson (ZIP), and negative binomial (NB) distributions. We selected distributions based on the model's $\mathrm{AIC}_{c}$ value and whether the models converged. We selected the ZIP distribution for D. fuscus adults, $D$. monticola adults, D. ochrophaeus adults, Eurycea spp. adults, and Eurycea spp. larvae. We selected the Poisson distribution for G. porphyriticus larvae. No models converged when the NB distribution was used. We assessed goodness-of-fit using the most complex candidate model and a 1,000-replication parametric bootstrap of the Pearson chi-square statistic (Kéry and Royle, 2016). Goodness-of-fit tests revealed some overdispersion in the models for all species ( $D$. fuscus c-hat $=2.49 ;$ D. monticola $\mathrm{c}$-hat $=2.08 ;$ D. ochrophaeus $\mathrm{c}-$ hat $=2.14 ;$ Eurycea spp. adults $\mathrm{c}-$ hat $=1.36 ;$ . porphyriticus c-hat $=2.05)$. We accounted for this overdispersion by ranking models using Quasi Akaike's information criterion, corrected for small sample $\left(\mathrm{QAIC}_{c}\right.$; Symonds and Moussalli, 2011).

We first determined the strongest predictor(s) of detection probability $(p)$ for each salamander species. We tested relative humidity (\%), number of cover objects flipped, water temperature $\left({ }^{\circ} \mathrm{C}\right.$; linear and quadratic), air temperature $\left({ }^{\circ} \mathrm{C}\right.$; linear and quadratic $)$, and water depth (linear and quadratic). For all species, we also tested one additive model containing the two predictors with the lowest $\mathrm{QAIC}_{c}$ (Table 3-1). We retained the most parsimonious $p$ submodel for all further analyses. Next, we determined the strongest habitat predictors of stream salamander abundances for each species. We tested water total dissolved solids (TDS; ng/mL), water $\mathrm{pH}$, hemlock basal area per ha, total canopy cover (\%), benthic macroinvertebrate biomass, locality (MNF or NPS), and \% rock for all species. We tested one additive model for each species containing the two predictors with the lowest QAIC $_{c}$ (Table 3-2). We retained the habitat variables from the most parsimonious model for each species for all further analyses.

After selecting the most parsimonious $p$ submodel and habitat variables, we individually tested and ranked four predictors of imidacloprid exposure: imidacloprid water concentration (ng/mL), number of imidacloprid applications, presence/absence of treated trees, and presence/absence of environmental imidacloprid. The number of imidacloprid applications 
represented the total number of trees treated at a site, including retreatments of individual trees across years, and thus served as a measure of treatment intensity. We defined presence of environmental imidacloprid as imidacloprid being detected in the stream water or sediment, imidacloprid metabolites being detected in the stream water or sediment, or treated trees being present.

We used $\triangle \mathrm{QAIC}_{c}$ and Akaike weight $\left(w_{i}\right)$ to assess model support, and considered candidate models to have some support when $\Delta \mathrm{AIC}_{c}<7$ (Burnham et al. 2011). We conducted $N$-mixture model analyses using the package unmarked (Fiske et al. 2019; version $0.12-2$ ) in program R (R Core Team 2019; version 3.4.1), and model selection analyses using the package AICcmodavg (Mazerolle 2019; version 2.1-1) in program R.

\section{RESULTS}

\subsection{Water and Sediment Imidacloprid Concentration}

Of the 48 sampled sites, 27 were directly adjacent to HWA treatments. Imidacloprid was detected in the stream water at 24 sites, with a mean concentration of $49.83 \pm 20.22 \mathrm{ng} / \mathrm{mL}$ (range $=6.52-489.56 \mathrm{ng} / \mathrm{mL}$; Table 1-1). Imidacloprid-urea was not detected in the stream water at any site. We detected imidacloprid-olefin in the water at two sites, and we detected imidacloprid in the water at both sites with detectable levels of imidacloprid-olefin. Imidacloprid was detected in sediment at four sites, three of which were adjacent to HWA treatments. We did not detect imidacloprid-olefin or imidacloprid-urea in the sediment at any site.

\subsection{Salamander Abundances}

We captured 431 D. fuscus adults, 496 D. monticola adults, 269 D. ochrophaeus adults, 125 Eurycea spp. adults, and 249 G. porphyriticus larvae. Of the 48 sampled sites, we detected D. fuscus adults at 36 sites, D. monticola adults at 40 sites, D. ochrophaeus adults at 35 sites, Eurycea spp. adults at 34 sites, and G. porphyriticus larvae at 41 sites. Mean estimated abundance per site was 13.3 for $D$. fuscus adults, 5.5 for $D$. monticola adults, 8.4 for $D$. ochrophaeus adults, 6 for Eurycea spp. adults, and 4.1 for G. porphyriticus larvae. 


\subsection{Detection Probability}

The variables included in the most parsimonious $p$ submodels varied among the species (Table 3-1). Number of cover objects flipped was a strong predictor for D. monticola. Relative humidity was a strong predictor for D. monticola, D. ochrophaeus, and Eurycea spp. In addition, air temperature (linear) was important for Eurycea spp., water depth (quadratic) was important for D. ochrophaeus, and water depth (linear) was important for D. fuscus. Water temperature was also important for $D$. fuscus. The most parsimonious $p$ submodel for $G$. porphyriticus was the null model (Table 3-1).

\subsection{Habitat Variables}

The most influential habitat variables also varied among the species (Table 3-2). The most parsimonious model for D. fuscus abundance included TDS $\left(w_{i}=0.49\right)$, and the most supported abundance submodel for $D$. monticola included $\mathrm{pH}$ and hemlock basal area $\left(w_{i}=\right.$ 0.78). The most parsimonious model for $D$. ochrophaeus included $\%$ rock $\left(w_{i}=0.47\right)$. The most parsimonious model for Eurycea spp. included TDS and canopy cover $\left(w_{i}=0.32\right)$, and for $G$. porphyriticus included biomass and TDS $\left(w_{i}=0.40\right)$.

\subsection{Imidacloprid Exposure}

For all species except Eurycea spp., the null model (i.e., $p$ variables and habitat variablesonly) received higher support than models containing a predictor of imidacloprid exposure (Table 3-3). For Eurycea spp., the most supported model contained presence/absence of environmental imidacloprid (Table 3-3), with presence positively correlated with abundance (Table 3-4). For all species, models containing predictors of imidacloprid exposure did have some support (Table 3-3). The four imidacloprid predictors were negatively correlated with $D$. fuscus abundances, but confidence intervals for all models except for number of imidacloprid applications overlapped with 0 . Number of imidacloprid applications had a negative relationship with abundances for D. fuscus, D. monticola, and D. ochrophaeus, but the $95 \%$ confidence interval for D. ochrophaeus overlapped with 0 . Presence of environmental imidacloprid also had a negative relationship with $D$. monticola and D. ochrophaeus abundances, and presence of treated trees had a negative relationship with $D$. ochrophaeus abundances. The abundances of $D$. 
monticola, D. ochrophaeus, Eurycea spp., and G. porphyriticus had inconsistent directional relationships with imidacloprid predictors and the imidacloprid predictors (except number of applications) had inconsistent directional relationships across species (Table 3-4).

\section{DISCUSSION}

Our results suggest that Desmognathus spp. abundances may be negatively affected by HWA treatments, particularly number of imidacloprid applications and presence of treated trees. However, we did not detect negative effects of imidacloprid exposure on Eurycea spp. or G. porphyriticus. Previous studies have documented co-occurring salamander species having differing responses to water quality degradation (Ryan et al. 2013). Obtaining different responses among species could be due to physiological differences, habitat use, or activity patterns.

Widespread application of pesticides and herbicides to the global environment has prompted studies which thus far have largely focused on physiological changes or impacts of agricultural pesticides on amphibian populations (Brühl et al. 2011). Substantial anuran declines in agricultural regions of California have been linked to pesticide exposure (Davidson 2004, Sparling et al. 2001). Laboratory studies have shown that common pesticides can be lethally toxic, decrease survival and survival to metamorphosis, and induce sublethal effects such as altered behavior (Brühl et al. 2011, Metts et al. 2005). Exposure to chemical contaminants may cause physiological changes in salamanders for months after exposure (Rohr 2009). Exposure to pesticides and insecticides also induces immune system suppression and may increase susceptibility to infectious diseases (Forson and Storfer 2006, Kerby and Storfer 2009).

In two concurrent studies, we documented physiological changes in salamanders due to HWA treatments and imidacloprid exposure. Sublethal effects of imidacloprid exposure on salamanders included bioaccumulation, reduced body condition indices, increased levels of the stress hormone corticosterone, and impeded feeding behavior (see thesis chapter 2 and appendix 2-1). In these studies, we were not able to assess the potential sublethal effects of imidacloprid exposure on G. porphyriticus or Eurycea spp., but we did detect both sublethal changes and potential population level effects in Desmognathus spp. Future research will benefit from examining relationships between sublethal effects and population level effects for diverse amphibian species. Assessing what level of sublethal effects will correspond with a population level effect will also be beneficial to forest managers. 
In this study, we were only able to assess the effects of imidacloprid on salamander juveniles for G. porphyriticus because of a low sample size for Desmognathus larva and poorlyfitting models for Eurycea spp. juveniles. Researching potential impacts on juvenile amphibians is an important avenue for future research on HWA treatments because previous research has shown that juvenile and subadult amphibians have strong responses to pesticide exposure, likely due to their high surface-to-volume ratio (Brïhl et al. 2011). Additionally, potential effects of HWA treatments on terrestrial salamanders are important to examine because they may have an increased proximity to treated hemlocks.

The goal of this study was to inform managers of any unintended effects of imidacloprid treatment on adjacent stream salamander populations. Hemlocks are a foundation species and imidacloprid application will be necessary throughout much of the Eastern U.S. until other alternatives to imidacloprid are developed (Ellison 2014, Havill et al. 2014). To our knowledge, this was the first field-based study investigating the effects of imidacloprid treatments on salamanders. We detected potential negative effects on Desmognathus spp. abundances, and thus encourage managers to use caution when applying imidacloprid near streams or in areas with the potential for imidacloprid to move into a stream. More field-based studies assessing the realworld effects of HWA treatment are necessary to allow for well-informed forest management decisions.

\section{ACKNOWLEDGMENTS}

Funding for this research was provided by the U.S. Geological Survey-National Park Service Water Quality Partnership Program and the West Virginia University Program to Stimulate Competitive Research. The West Virginia Division of Natural Resources and National Park Service provided field housing. The WV Cooperative Fish and Wildlife Research Unit provided field vehicles. We thank Dr. Terrance McManus, Dr. Kang Mo Ku, Dr. Moo Jung Kim, and Tyler Simpson for assistance with chemical analyses. We thank John Perez, Layne Strickler, and Lenza Paul for assistance with site selection and information on treatment histories. We thank Allison Fulcher, Sam Wilson, Devin Hoffer, and Kait Sudol for assistance with salamander sampling. We are thankful to Justin Hatcher for allowing us to access his private property. Donald Brown was supported by the USDA National Institute of Food and Agriculture, McIntire Stennis project WVA00122, and the West Virginia Agricultural and Forestry Experiment 
Station. Any use of trade, product, or firm names is for descriptive purposes only and does not imply endorsement by the U.S. Government.

\section{LITERATURE CITED}

Ade, C.M., Boone, M.D., Puglis, H.J. 2010. Effects of an insecticide and potential predators on green frogs and northern cricket frogs. Journal of Herpetology, 44(4): 591-601.

Becker, D.A., Brittingham, M.C., Goguen, C.B. 2008. Effects of hemlock woolly adelgid on breeding birds at Fort Indiantown Gap, Pennsylvania. Northeastern Naturalist, 15(2): $227-240$.

Benke, A.C., Huryn, A.D., Smock, L.A., Wallace, J.B. 1999. Length-mass relationships for freshwater macroinvertebrates in North America with particular reference to the southeastern United States. Journal of the North American Benthological Society, 18(3): 308-343.

Benton, E.P., Grant, J.F., Mueller, T.C., Webster, R.J., Nichols, R.J. 2016. Consequences of imidacloprid treatments for hemlock woolly adelgid on stream water quality in the southern Appalachians. Forest Ecology and Management, 360(2016): 152-158.

Bruce, R.C. 1989. Life history of the salamander Desmognathus monticola, with a comparison of the larval periods of D. monticola and D. ochrophaeus. Herpetologica, 1989: 44-155.

Brühl, C.A., Pieper, S., Weber, B. 2011. Amphibians at risk? Susceptibility of terrestrial amphibian life stages to pesticides. Environmental Toxicology and Chemistry, 30(11): 2465-2472.

Burnham, K.P., Anderson, D.R., Huyvaert, K.P. 2011. AIC model selection and multimodel inference in behavioral ecology: some background, observations, and comparisons. Behavioral Ecology and Sociobiology 65: 23-35.

Burton, T.M., Likens, G.E. 1975. Salamander populations and biomass in the Hubbard Brook Experimental Forest, New Hampshire. Copeia, 1975(3): 541-546.

Churchel, M.A., Hanula, J.L., Berisford, C.W., Vose, J.M., Dalusky, M.J. 2011. Impact of imidacloprid for control of hemlock woolly adelgid on nearby aquatic macroinvertebrate assemblages. Southern Journal of Applied Forestry, 35(1): 26-32.

Danstedt Jr, R.T. 1975. Local geographic variation in demographic parameters and body size of Desmognathus fuscus (Amphibia: Plethodontidae). Ecology, 56(5): 1054-1067.

Davic, R.D., Welsh, H.H. 2004. On the ecological roles of salamanders. Annual Review of Ecology, Evolution, and Systematics, 35(2004): 405-434. 
Davidson, C. 2004. Declining downwind: amphibian population declines in California and historical pesticide use. Ecological Applications, 14(6): 1892-1902.

Davidson, C., Knapp, R.A. 2007. Multiple stressors and amphibian declines: dual impacts of pesticides and fish on yellow-legged frogs. Ecological Applications, 17(2): 587-597.

Ding, T., Jacobs, D., Lavine, B.K. 2011. Liquid chromatography-mass spectrometry identification of imidacloprid photolysis products. Microchemical Journal, 99(2): 535541.

Ellison, A.M. 2014. Experiments are revealing a foundation species: a case study of eastern hemlock (Tsuga canadensis). Advances in Ecology, 2014: article 456904.

Feng, S., Kong, Z., Wang, X., Zhao, L., Peng, P. 2004. Acute toxicity and genotoxicity of two novel pesticides on amphibian, Rana N. Hallowell. Chemosphere, 56(5): 457-463.

Fiske, I., Chandler, R., Miller, D., Royle, A., Kéry, M., Hostetler, J., Hutchinson, R., Smith, A., Kellner, K. 2019. Package "unmarked". Models for Data from Unmarked Animals. Available from https://web.archive.org/web/20190710031607/https://cran.rproject.org/web/packages/unmarked/unmarked.pdf

Forson, D.D., Storfer, A. 2006. Atrazine increases ranavirus susceptibility in the tiger salamander, Ambystoma tigrinum. Ecological Applications, 16(6): 2325-2332.

Gabor, C.R., Knutie, S.A., Roznik, E.A., Rohr, J.R. 2018. Are the adverse effects of stressors on amphibians mediated by their effects on stress hormones? Oecologia, 186(2): 393-404.

Gibbons, D., Morrissey, C., Mineau, P. 2015. A review of the direct and indirect effects of neonicotinoids and fipronil on vertebrate wildlife. Environmental Science and Pollution Research, 22(1): 103-118.

Haché, S., Pétry, T., Villard, M.-A. 2013. Numerical response of breeding birds following experimental selection harvesting in northern hardwood forests. Avian Conservation and Ecology, 8(1):4.

Hallmann, C.A., Foppen, R.P., van Turnhout, C.A., de Kroon, H., Jongejans, E. 2014. Declines in insectivorous birds are associated with high neonicotinoid concentrations. Nature, 511(7509): 341-343.

Havill, N.P., Vieira, L.C., Salom, S.M. 2014. Biology and control of hemlock woolly adelgid. USDA Forest Service, Forest Health Technology Enterprise Team, Morgantown, West Virginia.

Houlahan, J.E., Findlay, C.S., Schmidt, B.R., Meyer, A.H., Kuzmin, S.L. 2000. Quantitative evidence for global amphibian population declines. Nature, 404(6779): 752.

Kerby, J.L., Storfer, A. 2009. Combined effects of atrazine and chlorpyrifos on susceptibility of the tiger salamander to Ambystoma tigrinum virus. EcoHealth, 6(1): 91-98.

Kéry, M., Royle, J.A. 2016. Applied hierarchical modeling in ecology: analysis of distribution, abundance and species richness in R and BUGS. Academic Press, Waltham, MA, USA. 
Larson, D.L., McDonald, S., Hamilton, S.J., Fivizzani, A.J., Newton, W.E. 1998. Effects of the herbicide atrazine on Ambystoma tigrinum metamorphosis: duration, larval growth, and hormonal response. Physiological Zoology, 71(6): 671-679.

Liu, W., Zheng, W., Gan, J. 2002. Competitive sorption between imidacloprid and imidaclopridurea on soil clay minerals and humic acids. Journal of Agricultural and Food Chemistry, 50(23): 6823-6827.

Lowe, W.H., Bolger, D.T. 2002. Local and landscape-scale predictors of salamander abundance in New Hampshire headwater streams. Conservation Biology, 16(1): 183-193.

Matsuda, K., Buckingham, S.D., Kleier, D., Rauh, J.J., Grauso, M., Sattelle, D.B. 2001. Neonicotinoids: insecticides acting on insect nicotinic acetylcholine receptors. Trends in Pharmacological Sciences, 22(11): 573-580.

Mazerolle, M. 2019. Package “AICcmodavg”. Model selection and Multimodel Inference Based on (Q)AIC(c). Available from https://web.archive.org/web/20190710031635/https://cran.rproject.org/web/packages/AICcmodavg/AICcmodavg.pdf.

Metts, B.S., Hopkins, W.A., Nestor, J.P. 2005. Interaction of an insecticide with larval density in pond-breeding salamanders (Ambystoma). Freshwater Biology, 50(4): 685-696.

Orwig, D.A., Foster, D.R., Mausel, D.L. 2002. Landscape patterns of hemlock decline in New England due to the introduced hemlock woolly adelgid. Journal of Biogeography, 29(10-11): 1475-1487.

Pérez-Iglesias, J.M., de Arcaute, C.R., Nikoloff, N., Dury, L., Soloneski, S., Natale, G.S., Larramendy, M.L. 2014. The genotoxic effects of the imidacloprid-based insecticide formulation Glacoxan Imida on Montevideo tree frog Hypsiboas pulchellus tadpoles (Anura, Hylidae). Ecotoxicology and Environmental Safety, 104(2014): 120-126.

Petranka, J.W. 1998. Salamanders of the United States and Canada. Smithsonian Books, Washington, D.C., USA.

Petranka, J.W., Murray, S.S. 2001. Effectiveness of removal sampling for determining salamander density and biomass: a case study in an Appalachian streamside community. Journal of Herpetology, 35(1): 36-44.

R Core Team. 2019. R: a language and environment for statistical computing. R Foundation for Statistical Computing, Vienna, Austria. Available from https://web.archive.org/save/https://www.R-project.org/.

Relyea, R.A., Diecks, N. 2008. An unforeseen chain of events: lethal effects of pesticides on frogs at sublethal concentrations. Ecological Applications, 18(7): 1728-1742.

Rohr, J.R., Palmer, B.D. 2005. Aquatic herbicide exposure increases salamander desiccation risk eight months later in a terrestrial environment. Environmental Toxicology and Chemistry: An International Journal, 24(5): 1253-1258.

Royle, J.A., 2004. N-mixture models for estimating population size from spatially replicated counts. Biometrics, 60(1): 108-115. 
Ryan, M.E., Johnson, J.R., Fitzpatrick, B.M., Lowenstine, L.J., Picco, A.M., Shaffer, H.B. 2013. Lethal effects of water quality on threatened California salamanders but not on cooccurring hybrid salamanders. Conservation Biology, 27(1): 95-102.

Sabo, J.L., Bastow, J.L., Power, M.E. 2002. Length-mass relationships for adult aquatic and terrestrial invertebrates in a California watershed. Journal of the North American Benthological Society, 21(2): 336-343.

Snyder, C.D., Young, J.A., Lemarié, D.P., Smith, D.R. 2002. Influence of eastern hemlock (Tsuga canadensis) forests on aquatic invertebrate assemblages in headwater streams. Canadian Journal of Fisheries and Aquatic Sciences, 59(2): 262-275.

Southerland, M.T., Jung, R.E., Baxter, D.P., Chellman, I.C. Mercurio, G., Vølstad, J.H. 2004. Stream Salamanders as Indicators of Stream Quality in Maryland, USA. Applied Herpetology, 2(1): 23-46.

Sparling, D.W., Fellers, G.M., McConnell, L.L. 2001. Pesticides and amphibian population declines in California, USA. Environmental Toxicology and Chemistry: An International Journal, 20(7): 1591-1595.

Stuart, S.N., Chanson, J.S., Cox, N.A., Young, B.E., Rodrigues, A.S., Fischman, D.L., Waller, R.W. 2004. Status and trends of amphibian declines and extinctions worldwide. Science, 306 (5702): 1783 - 1786.

Symonds, M.R., Moussalli, A. 2011. A brief guide to model selection, multimodel inference and model averaging in behavioural ecology using Akaike's information criterion. Behavioral Ecology and Sociobiology, 65(1): 13-21.

Tilley, S.G. 1980. Life histories and comparative demography of two salamander populations. Copeia, 4(1980): 806-821.

Tingley, M.W., Orwig, D.A., Field, R., Motzkin, G. 2002. Avian response to removal of a forest dominant: consequences of hemlock woolly adelgid infestations. Journal of Biogeography, 29(10-11): 1505-1516.

U.S. Environmental Protection Agency. 2003. Imidacloprid; Pesticide tolerances. Fed. Regist. 68, 35303-35315 [online]. http://www.epa.gov/fedrgstr/EPA-PEST/ 2003/June/Day13/p14880.htm. U.S. EPA, Washington, DC.

Quaranta, A., Bellantuono, V., Cassano, G., Lippe, C. 2009. Why amphibians are more sensitive than mammals to xenobiotics. PLoS ONE, 4(11): e7699.

Wamhoff, H., Schneider, V. 1999. Photodegradation of imidacloprid. Journal of Agricultural and Food Chemistry, 47(4): 1730-1734.

Welsh, Jr., H.H., Ollivier, L.M. 1998. Stream amphibians as indicators of ecosystem stress: a case study from California's redwoods. Ecological Applications, 8(4): 1118-1132.

Wiggins, G., Benton, E., Grant, J., Kerr, M., Lambdin, P. 2018. Short-term detection of imidacloprid in streams after applications in forests. Journal of Environmental Quality 47(3): 571-578.

Wood, P.B., Williams, J.M. 2013. Impact of valley fills on streamside salamanders in southern West Virginia. Journal of Herpetology, 47(1): 119-125. 
Yap, T.A., Koo, M.S., Ambrose, R.F., Wake, D.B., Vredenburg, V.T. 2015. Averting a North American biodiversity crisis. Science, 349(6247): 481-482. 
Table 3-1. Model selection results for detection $(p)$ submodels. Detection predictors tested included relative humidity $(\%)$, number of cover objects flipped, water temperature $\left({ }^{\circ} \mathrm{C}\right.$; linear and quadratic), air temperature $\left({ }^{\circ} \mathrm{C}\right.$; linear and quadratic), and water depth (linear and quadratic). For all species, we also tested one additive model containing the two predictors with the lowest $\mathrm{QAIC}_{c}$. Model selection was based on Quasi Akaike's Information Criterion corrected for small sample size $\left(\mathrm{QAIC}_{c}\right)$. The null model (.) only included the intercept.

\begin{tabular}{|c|c|c|c|c|}
\hline Model & Parameters & $\mathrm{QAIC}_{c}$ & $\Delta \mathrm{QAIC}_{c}$ & $\mathbf{W}_{i}$ \\
\hline \multicolumn{5}{|l|}{ D. fuscus adults } \\
\hline Water Temperature + Water Depth & 6 & 508.27 & 0.00 & 0.60 \\
\hline Water Temperature & 5 & 510.23 & 1.95 & 0.23 \\
\hline Water Temperature + Water Temperature ${ }^{2}$ & 6 & 512.67 & 4.39 & 0.07 \\
\hline (.) & 4 & 514.22 & 5.95 & 0.03 \\
\hline Water Depth & 5 & 514.80 & 6.52 & 0.02 \\
\hline Cover Objects & 5 & 515.62 & 7.34 & 0.02 \\
\hline Air Temperature & 5 & 515.90 & 7.63 & 0.01 \\
\hline Relative Humidity & 5 & 516.09 & 7.82 & 0.01 \\
\hline Water Depth + Water Depth ${ }^{2}$ & 6 & 517.94 & 9.67 & 0.00 \\
\hline Air Temperature + Air Temperature 2 & 6 & 518.45 & 10.17 & 0.00 \\
\hline Julian Date & 5 & 787.30 & 279.02 & 0.00 \\
\hline Julian Date + Julian Date ${ }^{2}$ & 6 & 790.18 & 281.90 & 0.00 \\
\hline \multicolumn{5}{|l|}{ D. monticola adults } \\
\hline Cover Objects + Relative Humidity & 6 & 443.00 & 0.00 & 0.97 \\
\hline Cover Objects & 5 & 450.14 & 7.14 & 0.03 \\
\hline Relative Humidity & 5 & 464.43 & 21.43 & 0.00 \\
\hline Air Temperature & 5 & 468.57 & 25.58 & 0.00 \\
\hline Air Temperature + Air Temperature 2 & 6 & 469.87 & 26.87 & 0.00 \\
\hline (.) & 4 & 471.37 & 28.37 & 0.00 \\
\hline Water Temperature & 5 & 471.86 & 28.86 & 0.00 \\
\hline Water Temperature + Water Temperature ${ }^{2}$ & 6 & 471.92 & 28.92 & 0.00 \\
\hline Water Depth & 5 & 473.85 & 30.85 & 0.00 \\
\hline Water Depth + Water Depth ${ }^{2}$ & 6 & 476.35 & 33.35 & 0.00 \\
\hline Julian Date & 5 & 611.38 & 168.38 & 0.00 \\
\hline Julian Date + Julian Date ${ }^{2}$ & 6 & 614.02 & 171.02 & 0.00 \\
\hline
\end{tabular}




\section{D. ochrophaeus adults}

Water Depth + Water Depth ${ }^{2}+$ Relative

Humidity

Water Depth + Water Depth ${ }^{2}$

Relative Humidity

(.)

Cover Objects

Water Depth

Air Temperature

Water Temperature

Air Temperature + Air Temperature ${ }^{2}$

Water Temperature + Water Temperature ${ }^{2}$

Julian Date

Julian Date + Julian Date ${ }^{2}$

$\begin{array}{rrrr}7 & 375.39 & 0 & 0.61 \\ 6 & 377.63 & 2.24 & 0.20 \\ 5 & 379.23 & 3.84 & 0.09 \\ 4 & 381.58 & 6.18 & 0.03 \\ 5 & 381.66 & 6.27 & 0.03 \\ 5 & 381.91 & 6.51 & 0.02 \\ 5 & 383.47 & 8.08 & 0.01 \\ 5 & 383.98 & 8.59 & 0.01 \\ 6 & 384.95 & 9.56 & 0.01 \\ 6 & 386.27 & 10.87 & 0.00 \\ 5 & 494.8 & 119.4 & 0.00 \\ 6 & 497.81 & 122.42 & 0.00\end{array}$

\section{Eurycea spp. adults}

Air Temperature + Relative Humidity

Relative Humidity

Air Temperature

Air Temperature + Air Temperature ${ }^{2}$

Water Depth

Water Temperature + Water Temperature ${ }^{2}$

Water Temperature

(.)

Water Depth + Water Depth ${ }^{2}$

Cover Objects

Julian Date

Julian Date + Julian Date ${ }^{2}$

$\begin{array}{rrrr}6 & 359.52 & 0.00 & 0.63 \\ 5 & 360.62 & 1.09 & 0.37 \\ 5 & 374.58 & 15.06 & 0.00 \\ 6 & 375.40 & 15.87 & 0.00 \\ 5 & 398.62 & 39.10 & 0.00 \\ 6 & 399.94 & 40.41 & 0.00 \\ 5 & 401.04 & 41.52 & 0.00 \\ 4 & 403.77 & 44.25 & 0.00 \\ 6 & 409.83 & 50.30 & 0.00 \\ 5 & 419.20 & 59.68 & 0.00 \\ 5 & 488.73 & 129.21 & 0.00 \\ 6 & 491.93 & 132.41 & 0.00\end{array}$

\section{G. porphyriticus larva}

(.)

Cover Objects

Relative Humidity

Air Temperature

Water Temperature

Water Depth

Cover Objects + Humidity

Water Temperature + Water Temperature ${ }^{2}$

Air Temperature + Air Temperature ${ }^{2}$

Water Depth + Water Depth ${ }^{2}$

Julian Date

\begin{tabular}{lrrr}
3 & 365.64 & 0.00 & 0.27 \\
4 & 365.82 & 0.17 & 0.25 \\
4 & 367.94 & 2.30 & 0.09 \\
4 & 367.94 & 2.30 & 0.09 \\
4 & 368.01 & 2.37 & 0.08 \\
4 & 368.02 & 2.37 & 0.08 \\
5 & 368.31 & 2.67 & 0.07 \\
5 & 369.95 & 4.31 & 0.03 \\
5 & 370.42 & 4.78 & 0.02 \\
5 & 370.54 & 4.90 & 0.02 \\
4 & 430.31 & 64.66 & 0.00 \\
5 & 435.09 & 69.44 & 0.00 \\
\hline
\end{tabular}


Table 3-2. Model selection results for habitat variables submodels. Habitat predictors tested included water total dissolved solids (TDS; ppm), water $\mathrm{pH}$, hemlock basal area per hectare, total canopy cover (\%), \% of plot covered by boulders or cobble, and benthic macroinvertebrate biomass. We also tested the predictor $\%$ bank leaf cover for D. ochrophaeus. For all species, we also tested one additive model containing the two predictors with the lowest $\mathrm{QAIC}_{c}$. Model selection was based on Quasi Akaike's Information Criterion corrected for small sample size $(\mathrm{QAIC})$. The null model (.) included the most parsimonious detection $(p)$ model.

\begin{tabular}{lcccc}
\hline Model & Parameters & QAIC $_{\boldsymbol{c}}$ & $\Delta \mathbf{Q A I C}_{\boldsymbol{c}}$ & $\mathbf{w}_{\boldsymbol{i}}$ \\
\hline $\boldsymbol{D}$. fuscus adults & & & & \\
TDS & 6 & 502.53 & 0.00 & 0.49 \\
TDS + pH & 7 & 503.84 & 1.30 & 0.25 \\
pH & 6 & 504.49 & 1.96 & 0.18 \\
Total Canopy & 6 & 507.80 & 5.27 & 0.03 \\
Locality & 6 & 509.45 & 6.91 & 0.02 \\
(.) & 5 & 510.23 & 7.69 & 0.01 \\
Hemlock Basal Area/ha & 6 & 510.95 & 8.41 & 0.01 \\
Biomass & 6 & 512.03 & 9.50 & 0.00 \\
\% Rock & 6 & 512.37 & 9.84 & 0.00
\end{tabular}

\section{D. monticola adults}

Hemlock Basal Area/ha +

$\mathrm{pH}$

$\mathrm{pH}$

Hemlock Basal Area/ha

(.)

Total Canopy

Locality

$\%$ Rock

Biomass

TDS

$\begin{array}{rrrr}8 & 432.82 & 0.00 & 0.78 \\ 7 & 435.76 & 2.94 & 0.18 \\ 7 & 440.10 & 7.29 & 0.02 \\ 6 & 443.00 & 10.18 & 0.00 \\ 7 & 443.62 & 10.80 & 0.00 \\ 7 & 444.10 & 11.29 & 0.00 \\ 7 & 444.48 & 11.67 & 0.00 \\ 7 & 445.16 & 12.34 & 0.00 \\ 7 & 445.37 & 12.55 & 0.00\end{array}$

\section{D. ochrophaeus adults}

$\begin{array}{lrrrr}\text { \% Rock } & 8 & 372.22 & 0 & 0.47 \\ \text { \% Rock + Total Canopy } & 9 & 373.74 & 1.52 & 0.22 \\ \text { (.) } & 7 & 375.39 & 3.18 & 0.1 \\ \text { Total Canopy } & 8 & 375.79 & 3.57 & 0.08 \\ \text { pH } & 8 & 376.52 & 4.3 & 0.05 \\ \text { TDS } & 8 & 377.71 & 5.5 & 0.03 \\ \text { Biomass } & 8 & 377.93 & 5.71 & 0.03 \\ \text { Hemlock Basal Area/ha } & 8 & 378.28 & 6.06 & 0.02 \\ \text { Locality } & 8 & 382 & 9.78 & 0\end{array}$


Eurycea spp. adults

Total Canopy + TDS

TDS

Total Canopy

Locality

(.)

Biomass

$\mathrm{pH}$

Hemlock Basal Area/ha

$\%$ Rock

$\begin{array}{lrrr}8 & 354.23 & 0 & 0.32 \\ 7 & 354.49 & 0.26 & 0.28 \\ 7 & 354.79 & 0.56 & 0.24 \\ 7 & 356.43 & 2.2 & 0.11 \\ 6 & 359.52 & 5.29 & 0.02 \\ 7 & 361.04 & 6.81 & 0.01 \\ 7 & 361.18 & 6.95 & 0.01 \\ 7 & 362.2 & 7.97 & 0.01 \\ 7 & 362.27 & 8.04 & 0.01\end{array}$

\section{G. porphyriticus larva}

Biomass + TDS

Biomass

TDS

$\%$ Rock

(.)

Locality

$\mathrm{pH}$

\begin{tabular}{llll}
5 & 361.64 & 0.00 & 0.40 \\
4 & 362.43 & 0.80 & 0.27 \\
4 & 363.93 & 2.29 & 0.13 \\
4 & 365.47 & 3.83 & 0.06 \\
3 & 365.64 & 4.01 & 0.05 \\
4 & 367.33 & 5.69 & 0.02 \\
4 & 367.66 & 6.02 & 0.02 \\
4 & 367.72 & 6.09 & 0.02 \\
4 & 367.93 & 6.29 & 0.02 \\
\hline
\end{tabular}


Table 3-3. Model selection results for imidacloprid predictors. Predictors include imidacloprid concentration in the water (ng/mL; Concentration), number of imidacloprid applications

(Number), presence of environmental imidacloprid (Presence), presence of treated trees (Trees). Model selection was based on Quasi Akaike's Information Criterion corrected for small sample size $\left(\mathrm{QAIC}_{c}\right)$. The null model included the most parsimonious detection $(p)$ model and the most parsimonious habitat model.

\begin{tabular}{|c|c|c|c|c|}
\hline Model & Parameters & QAIC $_{c}$ & $\Delta \mathrm{QAIC}_{c}$ & $\mathbf{w}_{i}$ \\
\hline \multicolumn{5}{|l|}{ D. fuscus adults } \\
\hline TDS & 6 & 312.54 & 0.00 & 0.53 \\
\hline TDS + Trees & 7 & 315.17 & 2.63 & 0.14 \\
\hline TDS + Presence & 7 & 315.24 & 2.70 & 0.14 \\
\hline TDS + Concentration & 7 & 315.37 & 2.82 & 0.13 \\
\hline TDS + Number & 7 & 317.10 & 4.65 & 0.05 \\
\hline \multicolumn{5}{|l|}{ D. monticola adults } \\
\hline pH + Hemlock Basal Area/Acre & 8 & 432.82 & 0.00 & 0.42 \\
\hline pH + Hemlock Basal Area/Acre + Presence & 9 & 433.91 & 1.09 & 0.24 \\
\hline $\mathrm{pH}+$ Hemlock Basal Area/Acre + Trees & 9 & 434.59 & 1.78 & 0.17 \\
\hline pH + Hemlock Basal Area/Acre + Concentration & 9 & 435.76 & 2.95 & 0.10 \\
\hline $\mathrm{pH}+$ Hemlock Basal Area/Acre + Number & 9 & 436.17 & 3.35 & 0.08 \\
\hline \multicolumn{5}{|l|}{ D. ochrophaeus adults } \\
\hline Rock & 8 & 375.89 & 0.00 & 0.36 \\
\hline Rock + Trees & 9 & 377.38 & 1.50 & 0.17 \\
\hline Rock + Presence & 9 & 377.40 & 1.51 & 0.17 \\
\hline Rock + Number & 9 & 377.46 & 1.57 & 0.17 \\
\hline Rock + Concentration & 9 & 377.99 & 2.11 & 0.13 \\
\hline \multicolumn{5}{|l|}{ Eurycea spp. adults } \\
\hline TDS + Presence & 8 & 353.60 & 0.00 & 0.50 \\
\hline TDS & 7 & 354.49 & 0.88 & 0.32 \\
\hline TDS + Trees & 8 & 357.03 & 3.43 & 0.09 \\
\hline Trees + Concentration & 8 & 357.13 & 3.53 & 0.09 \\
\hline Trees + Number & 8 & 582.09 & 228.48 & 0.00 \\
\hline \multicolumn{5}{|l|}{ G. porphyriticus larva } \\
\hline Biomass & 4 & 362.43 & 0.00 & 0.38 \\
\hline Biomass + Concentration & 5 & 362.93 & 0.50 & 0.30 \\
\hline Biomass + Presence & 5 & 363.35 & 0.91 & 0.24 \\
\hline Biomass + Number & 5 & 365.54 & 3.10 & 0.08 \\
\hline Biomass + Trees & 5 & 373.98 & 11.54 & 0.00 \\
\hline
\end{tabular}


Table 3-4. Parameter estimate ( $\beta$ ) and standard errors (SE) for imidacloprid predictors. Predictors include imidacloprid concentration in the water $(\mathrm{ng} / \mathrm{mL}$; Concentration), number of imidacloprid applications (Number), presence of environmental imidacloprid (Presence), presence of treated trees (Trees).

\begin{tabular}{lrrr}
\hline Imidacloprid Predictor & $\boldsymbol{\beta}$ & SE & 95\% CI \\
\hline D. fuscus adults & & & \\
Concentration & -0.001 & 0.001 & $(-0.002-0.001)$ \\
Number & -0.001 & 0 & $(-0.0009--0.0006)$ \\
Presence & -0.22 & 0.13 & $(-0.47-0.02)$ \\
Trees & -0.21 & 0.12 & $(-0.43-0.02)$
\end{tabular}

\section{D. monticola adults}

Concentration

Number

Presence

Trees

\section{D. ochrophaeus adults}

Concentration

Number

Presence

Trees

Eurycea spp. adults

Concentration

Number

Presence

Trees

\section{G. porphyriticus larva}

Concentration

Number

Presence

Trees

$\begin{array}{rrr}0.001 & 0.001 & (-0.002-0.003) \\ -0.001 & 0 & (-0.001--0.0005) \\ -0.32 & 0.16 & (-0.63--0.01) \\ -0.26 & 0.16 & (-0.56-0.06)\end{array}$

$\begin{array}{rrr}0 & 0.0007 & (-0.001-0.002) \\ -0.0004 & 0.0005 & (-0.001-0.001) \\ -0.33 & 0.17 & (-0.66--0.007) \\ -0.33 & 0.15 & (-0.63--0.03)\end{array}$

$\begin{array}{rrr}-0.003 & 0.003 & (-0.008-0.003) \\ 0 & 0 & (-0.0002-0.0002) \\ 0.51 & 0 & (0.07-0.94) \\ 0.14 & 0.2 & (-0.25-0.52)\end{array}$

$0.002 \quad 0.001 \quad(0.0003-0.004)$

$0 \quad 0 \quad(-0.0003-0)$

$\begin{array}{lll}0.37 & 0.21 & (-0.05-0.79)\end{array}$

$\begin{array}{lll}-0.16 & 0.15 & (-0.45-0.12)\end{array}$


Appendix 3-1. Salamander sampling subplot layout. Each site had three $3.3 \times 2 \mathrm{~m}$ subplots with $1 \mathrm{~m}$ of the width on the bank and $1 \mathrm{~m}$ of the width in the stream channel.

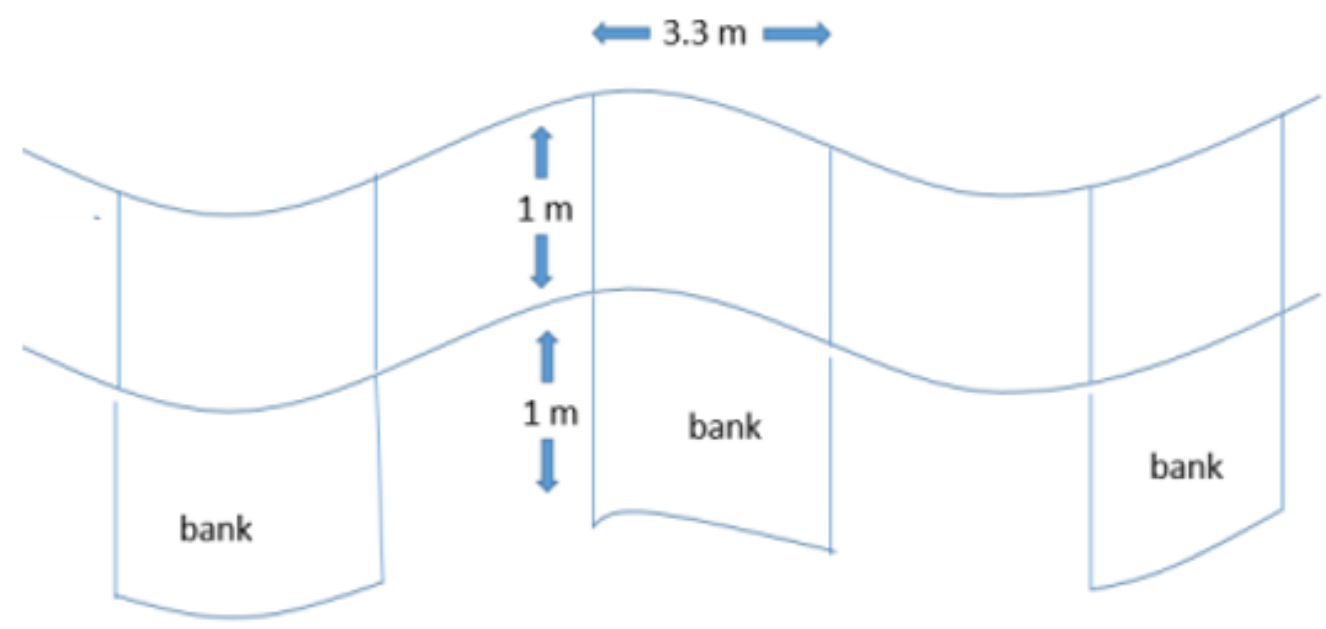

Subplot 1

Subplot 2

Subplot 3 
Appendix 3-2. Summary of means \pm SE for multiple measures of stream habitat for sites without environmental imidacloprid (absent; $\mathrm{n}=14$ ) and with environmental imidacloprid (present; $\mathrm{n}=34$ ). We defined sites as having environmental imidacloprid if imidacloprid or its metabolites were detected in the water or sediment, or if the stream was adjacent to HWA treatments.

\begin{tabular}{lrr}
\hline & Absent & Present \\
\hline Water Temp $\left({ }^{\circ} \mathrm{C}\right)$ & $14.71 \pm 0.57$ & $14.25 \pm 0.21$ \\
Water pH & $6.9 \pm 0.17$ & $6.9 \pm 0.08$ \\
Water Conductivity $(\mathrm{ng} / \mathrm{mL})$ & $62730 \pm 23000$ & $46760 \pm 10110$ \\
Water TDS $(\mathrm{ng} / \mathrm{mL})$ & $31520 \pm 12330$ & $23050 \pm 5080$ \\
Bank Leaf Cover $(\%)$ & $32.88 \pm 5.71$ & $32.65 \pm 3.48$ \\
Water Depth $(\mathrm{cm})$ & $7.68 \pm 1.79$ & $5.77 \pm 0.66$ \\
Wetted Stream Width $(\mathrm{cm})$ & $123.24 \pm 14.07$ & $133.34 \pm 12.98$ \\
Stream Gradient $\left({ }^{\circ}\right)$ & $8.12 \pm 1.30$ & $6.75 \pm 0.66$ \\
Total Canopy Cover $(\%)$ & $49.79 \pm 9.07$ & $58.94 \pm 6.11$ \\
Stream Substrate $(\%)$ & & \\
\% Sand & $14.79 \pm 3.85$ & $16.82 \pm 2.68$ \\
\% Gravel & $12.67 \pm 2.85$ & $14.2 \pm 2.19$ \\
\% Cobble & $33.24 \pm 4.86$ & $30.1 \pm 4.05$ \\
\% Boulder & $8.98 \pm 2.69$ & $16.67 \pm 3.4$ \\
\% Bedrock & $3.57 \pm 2.38$ & $0.87 \pm 0.53$ \\
\% Pebble & $8.26 \pm 1.79$ & $7.35 \pm 1.37$ \\
\% Silt & $12.05 \pm 4.29$ & $7.38 \pm 1.82$ \\
\% Detritus & $5.26 \pm 1.81$ & $4.76 \pm 1.01$ \\
Hemlock basal area/ha & $61.46 \pm 13.49$ & $86.94 \pm 11.24$ \\
Biomass (g) & $227.29 \pm 43.21$ & $201.22 \pm 33.82$ \\
\hline
\end{tabular}


Appendix 3-3. Summary of means \pm SE for number of salamanders detected during one survey per site in the Monongahela National Forest (MNF) and two units of the National Park Service (NPS) for sites without environmental imidacloprid (absent; $\mathrm{n}=14$ ) and with environmental imidacloprid (present; $n=34$ ). We defined sites as having environmental imidacloprid if imidacloprid or its metabolites were detected in the water or sediment, or if the stream was adjacent to HWA treatments.

\begin{tabular}{|c|c|c|c|c|}
\hline & \multicolumn{2}{|c|}{ MNF } & \multicolumn{2}{|c|}{ NPS } \\
\hline & Absent $(n=8)$ & Present $(n=16)$ & Absent $(n=7)$ & Present $(n=17)$ \\
\hline \multicolumn{5}{|l|}{ D. fuscus } \\
\hline adult & $0.28 \pm 0.15$ & $1.29 \pm 0.34$ & $1.75 \pm 0.75$ & $1.53 \pm 0.45$ \\
\hline juvenile & $0.02 \pm 0.02$ & $0.01 \pm 0.01$ & $0.14 \pm 0.12$ & $0.10 \pm 0.09$ \\
\hline \multicolumn{5}{|c|}{ D. monticola } \\
\hline adult & $2.25 \pm 0.58$ & $2.10 \pm 0.46$ & $1.17 \pm 0.28$ & $1.10 \pm 0.36$ \\
\hline juvenile & $0.13 \pm 0.11$ & $0.20 \pm 0.15$ & $0.11 \pm 0.09$ & $0.2 \pm 0.13$ \\
\hline \multicolumn{5}{|c|}{ D. ochrophaeus } \\
\hline adult & $1.42 \pm 0.60$ & $1.24 \pm 0.54$ & $0.28 \pm 0.18$ & $0.55 \pm 0.19$ \\
\hline juvenile & $0.00 \pm 0.00$ & $0.08 \pm 0.08$ & $0.00 \pm 0.00$ & $0.02 \pm 0.02$ \\
\hline \multicolumn{5}{|c|}{$\begin{array}{l}\text { Desmognathus } \\
\text { spp. }\end{array}$} \\
\hline adult & $0.14 \pm 0.14$ & $0.27 \pm 0.17$ & $0.89 \pm 0.39$ & $0.59 \pm 0.28$ \\
\hline juvenile & $0.04 \pm 0.04$ & $0.04 \pm 0.04$ & $0.19 \pm 0.15$ & $0.25 \pm 0.17$ \\
\hline \multicolumn{5}{|c|}{ Eurycea spp. } \\
\hline adult & $0.22 \pm 0.16$ & $0.32 \pm 0.21$ & $0.64 \pm 0.34$ & $0.56 \pm 0.33$ \\
\hline juvenile & $0.21 \pm 0.17$ & $0.70 \pm 0.65$ & $6.11 \pm 2.49$ & $2.68 \pm 0.99$ \\
\hline \multicolumn{5}{|c|}{ G. porphyriticus } \\
\hline adult & $0.00 \pm 0.00$ & $0.10 \pm 0.06$ & $0.00 \pm 0.00$ & $0.00 \pm 0.00$ \\
\hline juvenile & $0.64 \pm 0.25$ & $0.81 \pm 0.31$ & $0.56 \pm 0.21$ & $1.06 \pm 0.41$ \\
\hline \multicolumn{5}{|c|}{ Total captures } \\
\hline adult & $4.26 \pm 0.88$ & $4.84 \pm 0.95$ & $4.72 \pm 1.11$ & $4.31 \pm 1.01$ \\
\hline juvenile & $1.04 \pm 0.40$ & $1.84 \pm 0.94$ & $7.11 \pm 2.58$ & $4.07 \pm 1.15$ \\
\hline
\end{tabular}




\title{
CHAPTER 4: BENTHIC MACROINVERTEBRATE COMMUNITY RESPONSES TO IMIDACLOPRID EXPOSURE
}

\begin{abstract}
Hemlock woolly adelgid is an invasive insect that is causing widespread declines in eastern hemlock (Tsuga canadensis). Currently, the most effective method of preventing hemlock loss is application of imidacloprid, a neonicotinoid insecticide. Concerns have been raised about the negative effects of imidacloprid application on non-target insects. Imidacloprid exposure can inhibit feeding and foraging, cause immobility, and lead to declines in emergence in benthic macroinvertebrates. In this study, we assessed the effects of imidacloprid application to benthic macroinvertebrate communities in adjacent streams. We sampled benthic macroinvertebrates in 48 headwater streams in the Monongahela National Forest (MNF) and two National Park Service (NPS) units, New River Gorge National River and Gauley River National Recreation Area, in West Virginia, 26 of which were directly adjacent to or downstream of imidacloprid applications. We calculated seven metrics of biotic integrity, including GLIMPSS, WVSCI, and biomass, and compared them to four measures of imidacloprid exposure. We found negative relationships between treated streams and community metrics at MNF sites, but not NPS sites, indicating that responses to imidacloprid exposure may vary by geographic region due to other past or current environmental factors. We also completed a community functional traits analysis and compared the traits to presence of imidacloprid in the environment and presence of treated trees. Functional traits did not differ between sites with and without environmental imidacloprid or treated trees, but variation in functional traits did differ in MNF. We conclude that application of imidacloprid appears to be negatively affecting benthic macroinvertebrate community composition in the MNF, but impacts are not strong in the NPS units.
\end{abstract}




\section{INTRODUCTION}

Eastern hemlock (Tsuga canadensis) is a late-successional and ecologically important species that provides critical habitat for diverse taxa such as birds, mammals, herpetofauna, and fish (Becker et al. 2008, Ellison 2014, Snyder et al. 2002, Tingley et al. 2002). Hemlocks typically grow near headwater streams and influence stream characteristics such as temperature, nutrient cycling, and the biotic communities within the streams (Ellison et al. 2010, Havill et al. 2014). Hemlock-dominated stands produce deep shade and slowly-decomposing litter, creating damp and cool microclimates (Mathewson 2009). These characteristics enable aquatic macroinvertebrate species that are intolerant of seasonal drying to persist in streams within hemlock forests, resulting in high macroinvertebrate diversity (Snyder et al. 2002). Several macroinvertebrate taxa show strong associations with hemlock forests (Snyder et al. 2002). However, hemlock populations are declining due to infestations by the invasive hemlock woolly adelgid (HWA; Adelges tsugae), which causes mortality in both eastern hemlock and the less widely distributed Carolina Hemlock (T. caroliniana) (Havill et al. 2014, Ward et al. 2004).

Treatment with the neonicotinic insecticide imidacloprid is one of the most commonly used and effective methods to manage HWA infestations (Webb et al. 2003), but it can leach from HWA treatment areas into adjacent stream systems (Benton et al. 2016, Churchel et al. 2011, Wiggins et al. 2018). Several characteristics of imidacloprid make it more susceptible to leaching than many other pesticides. Its high water solubility allows for leaching into groundwater and streams (US EPA 2003), while its low volatility and a low soil adsorption coefficient makes it highly mobile in soil with low organic matter (Ding et al. 2011, Liu et al. 2002). These characteristics, in conjunction with the general proximity of hemlock forests to riparian areas, increase the risk of imidacloprid leaching into stream systems (Ding et al. 2011). Although imidacloprid begins to break down quickly in surface water when exposed to sunlight, continual leaching into stream systems may maintain imidacloprid presence in stream systems near treated hemlocks (Benton et al. 2016, Wamhoff and Schneider 1999).

Numerous laboratory and mesocosm studies have demonstrated both sub-lethal and lethal impacts of imidacloprid on benthic macroinvertebrates. Imidacloprid can inhibit feeding and foraging behavior (Alexander et al. 2007, Kreutzweiser et al. 2008), cause immobility (Alexander et al. 2007), and prompt downstream drift, which is a reaction to environmental disturbances in which stressors such as toxicants cause invertebrates to become dislodged and 
move downstream (Beketov and Liess 2008, Berghahn et al. 2012). Pulses of low concentrations of imidacloprid led to decreases in survival and emergence of Ephemeroptera, Tanypodinae, and Orthocladiinae, and an increase in the survival of Radix spp., which is a non-sensitive genus of snail (Columbo et al. 2013). Pulses of imidacloprid simulating runoff during rain events caused significant declines in benthic macroinvertebrate abundances and community diversity (Pestana et al. 2009).

While laboratory studies have clearly shown that exposure to imidacloprid impacts benthic macroinvertebrates, previous field studies have found that effects are not always strong in real-world systems. In an agricultural system in the Netherlands, concentration of imidacloprid in surface water was strongly negatively correlated with abundance of aquatic macroinvertebrates (Van Dijk et al. 2013). In contrast, macroinvertebrate functional feeding group richness and life habit (i.e. burrower, clinger) richness did not differ between control streams and streams with known imidacloprid presence from HWA treatments in Great Smoky Mountains National Park (Benton et al. 2017). Similarly, benthic macroinvertebrate communities in streams adjacent to HWA treatments in Georgia and North Carolina did not respond negatively to imidacloprid exposure, however, imidacloprid was only detected in one study stream over the course of the study (Churchel et al. 2011).

The purpose of our study was to investigate whether HWA treatments using imidacloprid are adversely affecting benthic macroinvertebrate communities in adjacent headwater streams. To accomplish this goal, our objectives included: 1) quantify the concentration of imidacloprid and its metabolites, imidacloprid-urea and imidacloprid-olefin in the water and identify presence of imidacloprid and metabolites in sediment of streams near HWA treatments, and compare four measures of imidacloprid exposure to: 2) metrics of benthic macroinvertebrate abundance, diversity, and biomass, and 3) benthic macroinvertebrate traits and functional groups.

\section{METHODS}

\subsection{Study Sites}

This study was conducted in the Monongahela National Forest (MNF) and two units of the National Park Service (NPS): Gauley River National Recreational Area (GARI) and New River Gorge National River (NERI) in West Virginia, USA (Fig. 4-1). Hemlock stands in the MNF were treated with a single application of imidacloprid in 2014 or 2015. Hemlock stand 
treatments in NPS units began in 2006 and have continued annually, including multiple applications (1-7 times) at 10 of the sampling locations (Table 1-1). We did not select NPS treatment sites if the last treatment occurred prior to 2011.

We used ArcGIS 10.4 (ESRI 2016) to identify candidate streams based on proximity to HWA treatments. We visited candidate streams to determine whether the stream depth, stream substrate, and water flow speeds were suitable for sampling benthic macroinvertebrates. We made our final study site selections based on the suitability of the streams for sampling, the proximity of treated trees, or the absence of treatments for non-impacted sites. The average site adjacent to HWA treatments had $306 \pm 158.7$ occurrences of imidacloprid applications (range = 5-3993 applications), with applications representing individual tree treatments.

We sampled headwater streams for benthic macroinvertebrates in 24 sites in MNF, 14 sites in NERI, and ten sites in GARI. Of these 48 sites, 27 were directly adjacent to HWA treatments and 21 were not adjacent to HWA treatments. Sites that were not adjacent to HWA treatments were either a minimum of $100 \mathrm{~m}$ upstream of imidacloprid application or were in a watershed without known HWA treatments. We selected $100 \mathrm{~m}$ as a minimum distance because Benton et al. (2016) did not detect imidacloprid in stream sites that were 10-100 m upstream of HWA treatments. For all analyses, however, we excluded one sampled site in GARI that was an extreme outlier for its imidacloprid concentration and the number of invertebrates collected. This stream was an ephemeral, drying stream with only 1 pool of water available by the time sampling occurred. Only 1 macroinvertebrate was collected, and the site had the highest imidacloprid concentration $(489.6 \mathrm{ng} / \mathrm{mL}$ in the water).

\subsection{Water and Sediment Imidacloprid Extraction and Quantification}

See thesis chapter 2, sections 2.2 and 2.3 for water and sediment sampling, imidacloprid extraction, and imidacloprid quantification methods.

\subsection{Benthic macroinvertebrate sampling}

During May-June 2017 and May-July 2018, we sampled macroinvertebrates at three 0.3 x 2 m subplots within each stream site so that total area sampled per stream was $0.3 \times 6 \mathrm{~m}$. Because this study was concurrent with a study on stream salamanders, we collected samples adjacent to the salamander sampling plots (see thesis chapter 3, section 2.3). We collected the 
samples in riffles when available ( $\mathrm{n}=128$ subplots). When riffles were not present on sampling plots, we collected samples in runs $(n=12)$ or pools $(n=1)$. We collected invertebrates by placing a $0.3 \mathrm{~m}$ wide D-net flush with the bottom of the stream and disturbing the substrate upstream of the D-net for 30 seconds. We only conducted sampling in base flow conditions. We composited the three samples from each stream site into one sample and stored the invertebrates in $75 \%$ ethanol until identification.

All invertebrates were identified by a certified taxonomist to the lowest possible taxonomic level, except for Chironomidae, which were identified as either Tanypodinae or nonTanypodinae due to the high diversity of Chironomidae in WV (over 100 genera) and difficulty of identification to the genus level (Pond et al. 2011). All organisms in each sample were counted and body length of each was measured to the nearest mm using a millimeter grid placed underneath a Zeiss dissecting microscope (Carl Zeiss Microscope, Thornwood, New York). We estimated macroinvertebrate biomass by using the length of each individual and length-weight equations published in the literature (e.g. Benke et al. 1990; Sabo et al. 2002) and summed the biomass estimates to obtain total estimated biomass for each site.

\subsection{Benthic macroinvertebrate response metrics}

We calculated two assemblage-level multi-metric indices (MMI) to evaluate stream impairment status, GLIMPSS (CF) (genus level index of most probable stream status) and WVSCI (West Virginia Stream Condition Index). GLIMPSS (CF) is a variation of GLIMPSS that does not require genus-level identification of Chironomidae (Pond et al. 2011). GLIMPSS is calibrated by season and region and assigns metric values to each stream on a 100-point scale and then averages the scores to create the GLIMPSS score. If a sample was collected before June 1 of each year, we used the "mountain spring calculator", and if a sample was collected after June 1 of each year, we used the "mountain summer calculator" (Pond et al. 2011). We used slightly modified sampling methods (i.e. full sample processing and sampling a 0.3 x $6 \mathrm{~m}$ area) for calculating GLIMPSS, and therefore the GLIMPSS values in this study are not useable for their original purpose of identifying reference and stressed streams relative to all streams in WV. However, the GLIMPSS values are valid for comparing the sites in this study among each other. It is impossible to directly compare GLIMPSS scores across different seasons or regions, so we calculated a "percent of threshold" value for each sample by dividing the GLIMPPS score by the 
$5^{\text {th }}$ percentile for that region and multiplying by 100 . The $5^{\text {th }}$ percentile for the mountain spring sites was 53 and the $5^{\text {th }}$ percentile for the mountain summer sites was 55 . When comparing to the $5^{\text {th }}$ percentile of the reference distribution, streams with a percent of threshold value of $>100 \%$ are considered to be unimpaired and streams with a percent of threshold value of $<100 \%$ are considered to be impaired (Pond et al. 2011). WVSCI is a family-level MMI that is not stratified by season or region (Gerristen et al. 2000). It is calculated from six metrics: total number of families, number of Ephemeroptera + Plecoptera + Trichoptera (EPT) families, family-level Hilsenhoff Biotic Index (HBI), \% 2 dominant families, and \% Chironomidae individuals to give streams scores from $0-100$ (Gerristen et al. 2000).

In addition to GLIMPSS and WVSCI, we assessed total benthic macroinvertebrate biomass and four individual indices of biotic integrity that are used to calculate GLIMPSS values. These variables were genus richness, percentage of taxa which are EPT taxa (\% EPT), percent of taxa which are Chironomidae and Annelida (\% Chironomidae and Annelida), and percent of genera which are of the five most dominant genera (\%5 Dominant Genera). We predicted that GLIMPSS, WVSCI, and biomass would be lower in streams with imidacloprid presence. We also predicted that genus richness and percentage of taxa which are EPT taxa would be lower with imidacloprid presence, and that percentage of taxa which are Chironomidae and Annelida and percent of genera which are of the five most dominant genera would increase with imidacloprid presence.

\subsection{Statistical Analysis}

Prior to assessing responses of macroinvertebrate community metrics to imidacloprid exposure, we determined if there was strong geographic variation in site-level community composition, independent of imidacloprid application. We used non-metric multidimensional scaling (NMDS) to determine if site-level community composition varied among our study areas (i.e., MNF, NERI, and GARI). We also used permutational analysis of variance (perMANOVA) to test the null hypothesis that there were not significant differences in site-level community composition between study areas (Anderson 2001). The NMDS showed a strong geographic split between MNF and the two NPS localities (NERI and GARI) and perMANOVA detected significant differences in community composition between the MNF and NPS sites (Appendix 41). Thus, we included locality (MNF or NPS) as a predictor in all models containing predictors 
of imidacloprid exposure. We conducted the NMDS using the package vegan (Oksanen 2019; version 2.5 - 5) in program $\mathrm{R}$ ( $\mathrm{R}$ Core Team 2019; version 3.4.1).

We used linear regressions or beta regressions and a model selection approach using Akaike's Information Criterion corrected for small sample size $\left(\mathrm{AIC}_{c}\right)$ to assess responses of the seven community metrics to imidacloprid exposure (Burnham et al. 2011, Zuur et al. 2009). We used beta regressions for the metrics that represented percentages (transformed to proportions; Ferrari and Cribari-Neto 2004). We visually assessed assumptions of normality and heteroscedasticity using graphical diagnostics (Cribari-Neto and Zeileis 2010, Zuur et al. 2010). We square root transformed total biomass to satisfy the assumption of normality. For the \% EPT analysis, we removed three sites that represented proportions of 0 or 1 to facilitate model convergence. We created linear regressions using the generalized least squares (GLS) function and a constant variance structure in the package nlme (Pinheiro et al. 2016; version 3.1 - 137). We created beta regressions using the package betareg (Zeileis and Cribari-Neto 2018; version $3.1-2)$.

For each model selection, candidate models included an intercept-only (null) model, locality, and four predictors of imidacloprid exposure in our analyses: imidacloprid water concentration $(\mathrm{ng} / \mathrm{mL})$, number of imidacloprid applications, presence/absence of treated trees, and presence/absence of environmental imidacloprid (Table 4-1). The number of imidacloprid applications represented the total number of trees treated at a site, including retreatments of individual trees across years, and thus served as a measure of treatment intensity. We defined presence of environmental imidacloprid as imidacloprid being detected in the stream water or sediment, imidacloprid metabolites being detected in the stream water or sediment, or treated trees being present. For each imidacloprid exposure predictor, we included models containing additive and interactive effects with locality. We used $\Delta \mathrm{AIC}_{c}$ and Akaike weight $\left(w_{i}\right)$ to assess model support, and considered candidate models to have support when $\Delta \mathrm{AIC}_{c}<7$.

Finally, we assessed how imidacloprid in the environment relates to the prevalence of functional traits (e.g., feeding group, respiration type) within the macroinvertebrate communities. Functional traits analyses investigate changes in function across a community rather than only changes in taxa (Poff et al. 2006, Cummins 2016). We assigned 20 functional traits to each taxon using Poff et al. (2006), the EPA database (U.S. EPA 2012) when appropriate, or the next most similar known taxa (Appendix 4-2). We used NMDS and the Jaccard distance metric to compare 
functional groups between sites with and without environmental imidacloprid exposure, and between sites with and without treated trees (Legendre and Legendre 2012). We used permutational analysis of variance (perMANOVA) to test the null hypothesis that there were not significant differences in functional traits between groups (Anderson 2001). We also assessed differences in group variance using a multivariate homogeneity of groups dispersions test (Anderson 2006). We conducted the functional traits analyses using the package vegan in program R.

\section{RESULTS}

\subsection{Water and Sediment Imidacloprid Concentration}

Imidacloprid was detected in the stream water at 24 sites (Appendix 4-3). Excluding the one outlier site described in section 1.1, stream water had a mean concentration of $15.03 \pm 4.02$ $\mathrm{ng} / \mathrm{mL}$ (range $=6.52-121.43 \mathrm{ng} / \mathrm{mL}$ ). Imidacloprid-urea was not detected in the stream water at any site. We detected imidacloprid-olefin in the water at two sites, and we detected imidacloprid in the water at both sites with detectable levels of imidacloprid-olefin. Imidacloprid was detected in sediment at seven sites, four of which were adjacent to HWA treatments, and two of which had no imidacloprid detected in water (Table 1-1). We did not detect imidacloprid-olefin or imidacloprid-urea in the sediment at any site. Of the 47 sites used for analyses, we classified 33 sites as present and 14 sites as absent for environmental imidacloprid (Appendix 4-3).

\subsection{Community Metrics}

We collected 8764 benthic macroinvertebrates in this study, 7999 of which were identified to genus. Mean invertebrate abundance per site was $186.4 \pm 24.4$ and abundances per site ranged from 6 to 842 individuals.

The most parsimonious models for GLIMPSS, WVSCI, \% Chironomidae and Annelida, and \%5 Dominant Genera all included an interaction between locality and presence of environmental imidacloprid, and the second most supported model for biomass contained an interaction between locality and presence of environmental imidacloprid (Table 4-1). There was support for an additive model containing locality and water imidacloprid concentration for $\%$ EPT. An additive model containing locality and presence of treated trees was the second most supported for genus richness and was also a supported model for \% EPT. There also was 
evidence to support models containing number of imidacloprid applications and water concentration for all predictors except for \% 5 Dominant Genera.

Models containing locality received more support than the null model for all community metrics except biomass (Table 4-1). The directional effects of presence of environmental imidacloprid differed depending on locality (MNF or NPS) for four of the five models containing an interaction term (Table 4-2). GLIMPSS score, WVSCI score, and biomass were lower at sites with environmental imidacloprid in MNF and higher at sites with environmental imidacloprid in NPS (Fig. 4-2). \% Chironomidae and Annelida was similar at sites with and without environmental imidacloprid in MNF and NPS. Confidence intervals (95\% CI) for model predicted values mostly did not overlap for GLIMPSS and WVSCI in presence/absence MNF sites, but CIs overlapped for GLIMPSS and WVSCI in the NPS sites. CIs also overlapped for all other metrics between MNF and NPS presence/absence sites. Genus richness was negatively associated with presence of treated trees, but the CI overlapped 0 (Table 4-2). Percent EPT was positively associated with imidacloprid water concentration, but the CI overlapped 0 (Table 4-2).

A jaccard-based NMDS of MNF sites (stress = 0.0183) did not result in significantly different groups based on presence/absence of environmental imidacloprid ( $p=0.93$ ), however, the difference in variation between sites with and without environmental imidacloprid was significant $(p<0.05)$. A jaccard-based NMDS of NPS sites (stress $=0.0231)$ did not result in significantly different groups based on presence/absence of environmental imidacloprid ( $p=$ 0.31 ) and the difference in variation between sites with and without environmental imidacloprid was non-significant ( $p=0.55$; Fig. 4-3).

A jaccard-based NMDS of MNF sites (stress $=0.0183$ ) did not result in significantly different groups based on presence/absence of treated trees $(p=0.93)$, and the difference in variation between sites with and without treated trees was not significant $(p=0.74)$. A jaccardbased NMDS of NPS sites (stress $=0.0231$ ) did not result in significantly different groups based on presence/absence of treated trees $(p=0.74)$ and the difference in variation between sites with and without treated trees was non-significant ( $p=0.37$; Fig. 4-4).

\section{DISCUSSION}

The presence of environmental imidacloprid and the presence of treated trees are influential predictors of numerous indices of biotic integrity. We predicted that GLIMPSS, 
WVSCI, \%EPT, and biomass would be lower in sites with environmental imidacloprid, but this was only true for sites within MNF. In NPS, GLIMPSS, WVSCI, \%EPT, and biomass were higher in streams with environmental imidacloprid. Thus, imidacloprid exposure appeared to have a negative impact on benthic macroinvertebrate communities in MNF, but not NPS, sites.

There may be intrinsic differences in imidacloprid treatments or sites between MNF and NPS that we did not account for in this study that influenced the differences in community responses. For example, historical land uses continue to impact the abiotic and biotic environment in the Appalachian region (e.g. McTammany et al. 2007) and differences in historical land disturbances between MNF and NPS may have contributed to the different responses to imidacloprid exposure. During the early $20^{\text {th }}$ century, MNF, like much eastern National Forest land, was widely logged and clearcut and the NPS units were logged, mined, and disturbed by railroads (Good and Stasick 2008, Shands 1991). Mining can have strong and longlasting effects on benthic communities (Pond et al. 2014). Physical, chemical, and biological conditions of streams, including benthic macroinvertebrate metrics, are influenced by historical land uses, and historical land use may be more influential than current land use on benthic macroinvertebrate diversity (Harding et al. 1998, Maloney et al. 2008). Additionally, most MNF sites were treated with imidacloprid more recently than NPS sites, which also could have influenced the results. Imidacloprid concentrations are at their highest soon after treatment and during rain events (Churchel et al. 2011). It is possible that larger effects on invertebrate communities can be detected after precipitation washes high imidacloprid concentrations into streams. The assumption that there are additional external factors influencing responses at NPS sites is supported by the wide CI for every community metric (see Fig. 4-2), indicating there is a large amount of variance at these sites that our models do not explain.

We calculated both GLIMPSS and WVSCI to assess whether genus-level identification was necessary to detect changes in community composition. GLIMPSS and WVSCI had the same directional responses to presence of environmental imidacloprid and similar response magnitudes. Future studies assessing effects of HWA treatments in WV may be able to save resources by identifying samples only to family without decreasing the ability to detect changes. We did not detect a difference in community composition based on functional traits between sites with/without environmental imidacloprid or treated trees, but we did detect a difference in variation between sites with and without environmental imidacloprid in MNF. Variance 
increased in sites with environmental imidacloprid, indicating an increase in variation in what functional traits were present at each site. Increased variation may indicate the imidacloprid exposure is selectively removing certain traits from the communities. Further analyses are warranted investigating which functional traits or combinations of traits are more affected by imidacloprid treatments.

Although laboratory and mesocosm studies have documented sublethal and lethal effects of imidacloprid on benthic macroinvertebrates (Alexander et al. 2007, Beketov and Liess 2008, Berghahn et al. 2012, Kreutzweiser et al. 2008, Kreutzweiser et al. 2009), few previous studies have involved sampling streams adjacent to HWA treatments or sampling surface waters otherwise contaminated with imidacloprid. Two previous studies found no effect on benthic communities (Benton et al. 2017, Churchel et al. 2011), but our study did on the MNF. Additional research is needed to determine why responses varied between MNF and NPS sites. In addition, we did not assess crayfish populations in this study, but crayfish also are an important part of riparian trophic webs (Paul and Simonin 2006), and we encourage future research on effects of HWA treatments on crayfish. Continued research into community impacts of imidacloprid on stream arthropods is warranted given their importance as prey for many taxa.

Imidacloprid is being applied widely on public lands and continual imidacloprid application in forest systems will be needed to maintain ecosystem integrity until acceptable alternatives to pesticides treatment are developed (Havill et al. 2014). The wide-spread usage of neonicotinoids such as imidacloprid has raised concerns in recent years because of documented non-target impacts to diverse taxa (e.g. Gibbons et al. 2015, Hallman et al. 2014). The primary goal of our study was to assess the effects of imidacloprid application on benthic macroinvertebrate communities. We detected negative effects of imidacloprid exposure on multiple community metrics and differences in functional traits variation in MNF, and conclude that the effects of imidacloprid on community metrics is occurring but may be variable depending on location. We encourage managers to use caution when applying imidacloprid to forest systems, especially when risk of leaching into streams is high.

\section{ACKNOWLEDGMENTS}

Funding for this research was provided by the U.S. Geological Survey-National Park Service Water Quality Partnership Program and the West Virginia University Program to Stimulate 
Competitive Research. The West Virginia Division of Natural Resources and National Park Service provided field housing. The WV Cooperative Fish and Wildlife Research Unit provided field vehicles. We thank Dr. Terrance McManus, Dr. Kang Mo Ku, Dr. Moo Jung Kim, and Tyler Simpson for assistance with chemical analyses. We thank Brian Carlson for contributing his knowledge in benthic invertebrate identification. We thank John Perez, Layne Strickler, and Lenza Paul for assistance with site selection and information on treatment histories. We thank Allison Fulcher, Sam Wilson, Devin Hoffer, and Kait Sudol for assistance with benthic macroinvertebrate sampling, and Tyler Sylvester, Allie Brabham, and Jamie Saunders for sorting invertebrate samples. We are thankful to Justin Hatcher for allowing us to access his private property. Special thanks to Laura Farwell and George Merovich for assistance with analysis. Donald Brown was supported by the USDA National Institute of Food and Agriculture, McIntire Stennis project WVA00122, and the West Virginia Agricultural and Forestry Experiment Station. Any use of trade, product, or firm names is for descriptive purposes only and does not imply endorsement by the U.S. Government.

\section{LITERATURE CITED}

Alexander, A.C., Culp, J.M., Liber, K., Cessna, A.J. 2007. Effects of insecticide exposure on feeding inhibition in mayflies and oligochaetes. Environmental Toxicology and Chemistry, 26(8): 1726-1732.

Anderson, M.J. 2001. A new method for non-parametric multivariate analysis of variance. Austral ecology, 26(1): 32-46.

Anderson, M.J. 2006. Distance-based tests for homogeneity of multivariate dispersions. Biometrics, 62(1): 245-253.

Becker, D.A., Brittingham, M.C., Goguen, C.B. 2008. Effects of hemlock woolly adelgid on breeding birds at Fort Indiantown Gap, Pennsylvania. Northeastern Naturalist, 15(2): $227-240$.

Beketov, M.A., Liess, M. 2008. Potential of 11 pesticides to initiate downstream drift of stream macroinvertebrates. Archives of Environmental Contamination and Toxicology, 55(2): 247-253.

Benke, A.C., Huryn, A.D., Smock, L.A., Wallace, J.B. 1999. Length-mass relationships for freshwater macroinvertebrates in North America with particular reference to the southeastern United States. Journal of the North American Benthological Society, 18(3): 308-343. 
Benton, E.P., Grant, J.F., Mueller, T.C., Webster, R.J., Nichols, R.J. 2016. Consequences of imidacloprid treatments for hemlock woolly adelgid on stream water quality in the southern Appalachians. Forest Ecology and Management, 360(2016): 152-158.

Benton, E.P., Grant, J.F., Nichols, R.J., Webster, R.J., Schwartz, J.S., Bailey, J.K. 2017. Risk assessment of imidacloprid use in forest settings on the aquatic macroinvertebrate community. Environmental Toxicology and Chemistry, 36(11): 3108-3119.

Berghahn, R., Mohr, S., Hübner, V., Schmiediche, R., Schmiedling, I., Svetich-Will, E., Schmidt, R. 2012. Effects of repeated insecticide pulses on macroinvertebrate drift in indoor stream mesocosms. Aquatic Toxicology, 122(2012): 56-66.

Burnham, K.P., Anderson, D.R., Huyvaert, K.P. 2011. AIC model selection and multimodel inference in behavioral ecology: some background, observations, and comparisons. Behavioral Ecology and Sociobiology, 65(1): 23-35.

Churchel, M.A., Hanula, J.L., Berisford, C.W., Vose, J.M., Dalusky, M.J. 2011. Impact of imidacloprid for control of hemlock woolly adelgid on nearby aquatic macroinvertebrate assemblages. Southern Journal of Applied Forestry, 35(1): 26-32.

Colombo, V., Mohr, S., Berghahn, R., Pettigrove, V.J. 2013. Structural changes in a macrozoobenthos assemblage after imidacloprid pulses in aquatic field-based microcosms. Archives of Environmental Contamination and Toxicology, 65(4): 683-692.

Cribari-Neto, F., Zeileis, A. 2010. Beta regression in R. Journal of Statistical Software, 34(2): 124.

Cummins, K.W. 2016. Combining taxonomy and function in the study of stream macroinvertebrates. Journal of Limnology, 75(1): 235-241.

Ding, T., Jacobs, D., Lavine, B.K. 2011. Liquid chromatography-mass spectrometry identification of imidacloprid photolysis products. Microchemical Journal, 99(2): 535541.

Ellison, A.M. 2014. Experiments are revealing a foundation species: a case study of eastern hemlock (Tsuga canadensis). Advances in Ecology, 2014: Article ID 456904.

Ellison, A.M., Barker-Plotkin, A.A., Foster, D.R., Orwig, D.A. 2010. Experimentally testing the role of foundation species in forests: the Harvard Forest Hemlock Removal Experiment. Methods in Ecology and Evolution, 1(2): 168-179.

Environmental Systems Research Institute. 2016. Redlands, California, USA.

Ferrari, S., Cribari-Neto, F. 2004. Beta regression for modelling rates and proportions. Journal of Applied Statistics, 31(7): 799-815.

Gerritsen, J., Burton, J., Barbour, M.T., 2000. A Stream Condition Index for West Virginia Wadeable Streams. Tetra Tech, Inc., Owings Mills, Maryland.

Gibbons, D., Morrissey, C., Mineau, P. 2015. A review of the direct and indirect effects of neonicotinoids and fipronil on vertebrate wildlife. Environmental Science and Pollution Research, 22(1): 103-118.

Good, G.A., Stasick, L. 2008. New River Gorge National River administrative history. National Park Service. 
Hallmann, C.A., Foppen, R.P., van Turnhout, C.A., de Kroon, H., Jongejans, E. 2014. Declines in insectivorous birds are associated with high neonicotinoid concentrations. Nature, 511(7509): $341-343$.

Harding, J.S., Benfield, E.F., Bolstad, P.V., Helfman, G.S., Jones, E.B.D. 1998. Stream biodiversity: the ghost of land use past. Proceedings of the National Academy of Sciences, 95(25): 14843-14847.

Havill, N.P., Vieira, L.C., Salom, S.M. 2014. Biology and control of hemlock woolly adelgid. USDA Forest Service, Forest Health Technology Enterprise Team, Morgantown, West Virginia.

Kreutzweiser, D.P., Thompson, D.G., Scarr, T.A. 2009. Imidacloprid in leaves from systemically treated trees may inhibit litter breakdown by non-target invertebrates. Ecotoxicology and Environmental Safety, 72(4): 1053-1057.

Kreutzweiser, D.P., Good, K.P., Chartrand, D.T., Scarr, T.A., Thompson, D.G. 2008. Toxicity of the systemic insecticide, imidacloprid, to forest stream insects and microbial communities. Bulletin of Environmental Contamination and Toxicology, 80(3): 211-214.

Legendre, P., Legendre, L. 2012. Numerical Ecology. Elsevier, Amsterdam.

Liu, W., Zheng, W., Gan, J. 2002. Competitive sorption between imidacloprid and imidaclopridurea on soil clay minerals and humic acids. Journal of Agricultural and Food Chemistry, 50(23): 6823-6827.

Maloney, K.O., Feminella, J.W., Mitchell, R.M., Miller, S.A., Mulholland, P.J., Houser, J.N. 2008. Landuse legacies and small streams: identifying relationships between historical land use and contemporary stream conditions. Journal of the North American Benthological Society, 27(2): 280-294.

Mathewson, B. 2009. The relative abundance of eastern red-backed salamanders in eastern hemlock-dominated and mixed deciduous forests at Harvard Forest. Northeastern Naturalist, 16(1): 1-12.

McTammany, M.E., Benfield, E.F., Webster, J.R. 2007. Recovery of stream ecosystem metabolism from historical agriculture. Journal of the North American Benthological Society, 26(3): 532-545.

Oksanen, J. 2019. Package "vegan". An Introduction to Ordination. Available from https://web.archive.org/web/20190706155607/https://cran.rproject.org/web/packages/vegan/vignettes/intro-vegan.pdf.

Paul, E.A., Simonin, H.A. 2006. Toxicity of three mosquito insecticides to crayfish. Bulletin of Environmental Contamination and Toxicology, 76(4): 614-621.

Pestana, J.L.T., Alexander, A.C., Culp, J.M., Baird, D.J., Cessna, A.J., Soares, A.M.V.M. 2009. Structural and functional responses of benthic invertebrates to imidacloprid in outdoor stream mesocosms. Environmental Pollution, 157(8): 2328-2334.

Pinheiro, J. and Bates, D. 2019. Package "nlme". Linear and Nonlinear Mixed Effects Models. Available from https://web.archive.org/web/20190805170757/https://cran.rproject.org/web/packages/nlme/nlme.pdf. 
Poff, N.L., Olden, J.D., Vieira, N.K.M., Finn, D.S., Simmons, M.P., Kondratieff, B.C. 2006.

Functional trait niches of North American lotic insects: traits-based ecological applications in light of phylogenetic relationships. Journal of the North American Benthological Society, 25(4): 730-755.

Pond, G.J., Bailey, J.E., Lowman, B.M., Whitman, M.J. 2011. The West Virginia GLIMPSS (Genus Level Index of Most Probable Stream Status): A Benthic Macroinvertebrate Index of Biotic Integrity for West Virginia's Wadeable Streams. WV EPA Technical Report. DOI: 10.13140/RG.2.1.4536.3682.

Pond, G.J., Passmore, M.E., Pointon, N.D., Felbinger, J.K., Walker, C.A., Krock, K.J., Fulton, J.B. Nash, W.L. 2014. Long-term impacts on macroinvertebrates downstream of reclaimed mountaintop mining valley fills in central Appalachia. Environmental Management, 54(4): 919-933.

R Core Team. 2019. R: a language and environment for statistical computing. R Foundation for Statistical Computing, Vienna, Austria. URL https://web.archive.org/save/https://www.R-project.org/.

Sabo, J.L., Bastow, J.L., Power, M.E. 2002. Length-mass relationships for adult aquatic and terrestrial invertebrates in a California watershed. Journal of the North American Benthological Society, 21(2): 336-343.

Shands, W. E. 1991. The lands nobody wanted: the legacy of the eastern national forests. Washington, DC: Pinchot Institute.

Snyder, C.D., Young, J.A., Lemarié, D.P., Smith, D.R. 2002. Influence of eastern hemlock (Tsuga canadensis) forests on aquatic invertebrate assemblages in headwater streams. Canadian Journal of Fisheries and Aquatic Sciences, 59(2): 262-275.

Tingley, M.W., Orwig, D.A., Field, R., Motzkin, G. 2002. Avian response to removal of a forest dominant: consequences of hemlock woolly adelgid infestations. Journal of Biogeography, 29(10-11): 1505-1516.

U.S. EPA. Freshwater Biological Traits Database (Final Report). U.S. Environmental Protection Agency, Washington, DC, EPA/600/R-11/038F, 2012.

Van Dijk, T.C., Van Staalduinen, M.A., Van der Sluijs, J.P. 2013. Macro-invertebrate decline in surface water polluted with imidacloprid. PLoS ONE, 8(5): e62374.

Wamhoff, H., Schneider, V. 1999. Photodegradation of imidacloprid. Journal of Agricultural and Food Chemistry, 47(4): 1730-1734.

Ward, J.S., Montgomery, M.E., Cheah, C.A.J., Onken, B.P., Cowles, R.S. 2004. Eastern hemlock forests: guidelines to minimize the impacts of hemlock woolly adelgid. USDA Forest Service.

Webb, R.E., Frank, J.R., Raupp, M.J. 2003. Eastern hemlock recovery from hemlock woolly adelgid damage following imidacloprid therapy. Journal of Arboriculture, 29(5): 298302. 
Wiggins, G., Benton, E., Grant, J., Kerr, M., Lambdin, P. 2018. Short-term detection of imidacloprid in streams after applications in forests. Journal of Environmental Quality, 47(3): 571-578.

Zeileis, A, Cribari-Neto, F., Gruen B., Kosmidis, I. 2018. Package "betareg”. Beta regression. Available from https://web.archive.org/web/20190724170548/https://cran.rproject.org/web/packages/betareg/betareg.pdf

Zuur, A.F., Ieno, E.N., Elphick, C.S. 2010. A protocol for data exploration to avoid common statistical problems. Methods in Ecology and Evolution, 2010(1): 3-14.

Zuur, A.F., Ieno, E.N., Walker, N.J., Saveliev, A.A., Smith, G.M. 2009. Mixed effects models and extensions in ecology with R. Springer, New York, New York, USA. 

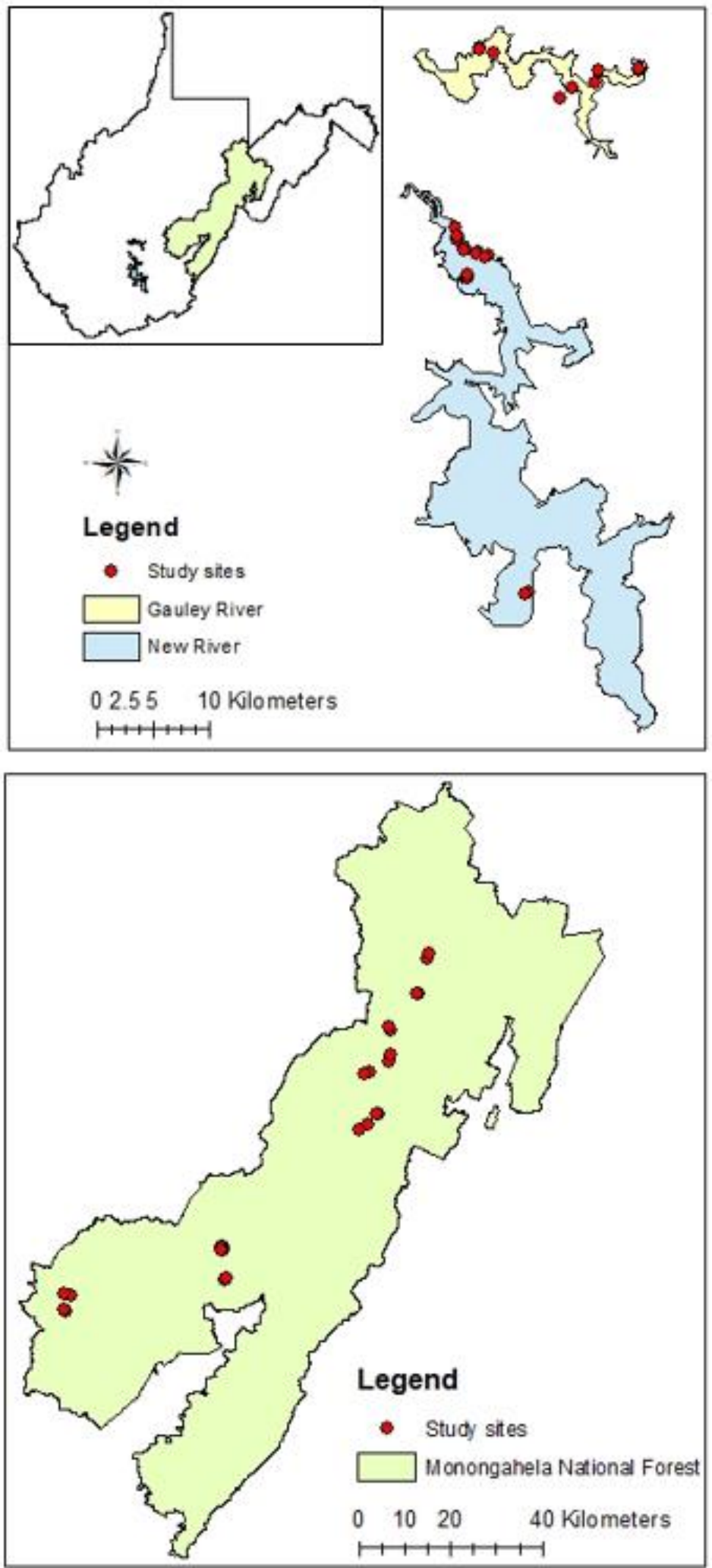

Figure 4-1. Locations of sampled streams within the Monongahela National Forest, New River Gorge National River, and Gauley River National Recreation Area. West Virginia (inset), USA. 

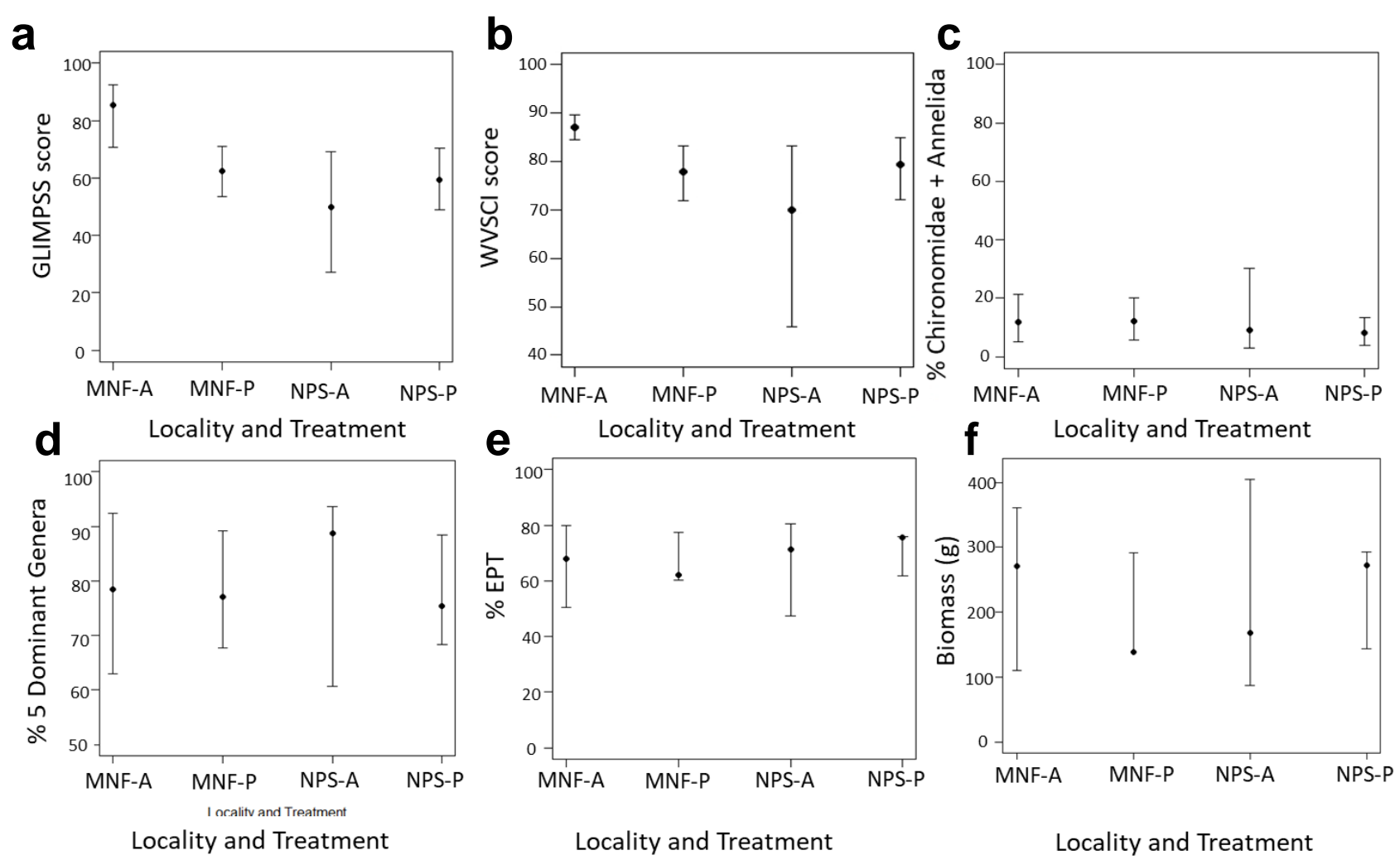

Figure 4-2. Model-estimated predictions and 95\% confidence intervals (CI) for (a) GLIMPSS, (b) WVSCI, (c) \% Chironomidae + Annelida, (d) \% 5 Dominant Genera, and (e) \% EPT and (f) total biomass. Predictions shown are for sites in the Monongahela National Forest without imidacloprid exposure (MNF-A; $\mathrm{n}=8$ ), Monongahela National Forest with imidacloprid exposure (MNF-P; $\mathrm{n}=16$ ); sites in the National Park Service without imidacloprid exposure (NPS-A; $n=6$ ); and sites in the National Park Service with imidacloprid exposure (NPS-P; $n=$ 17). 

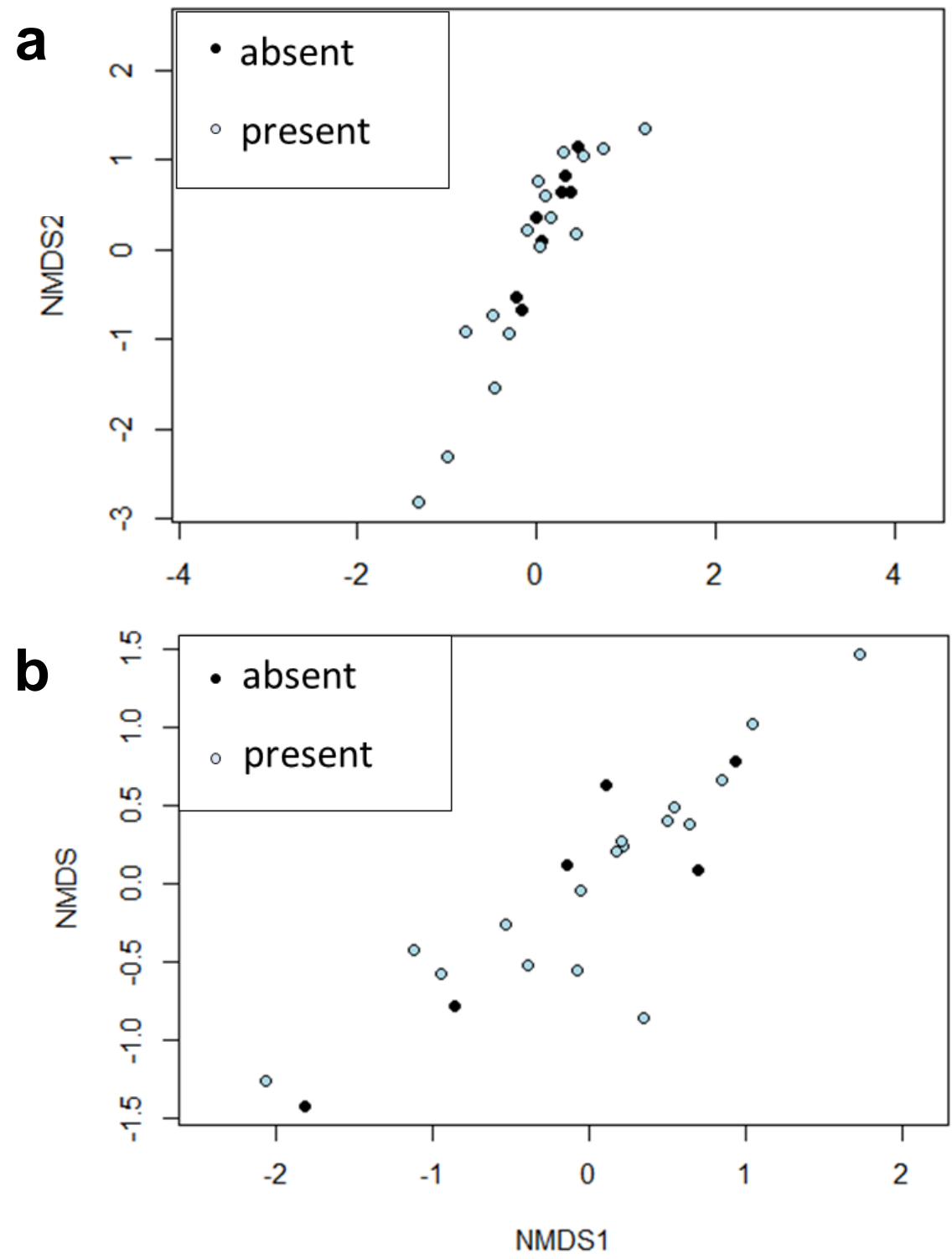

Figure 4-3. Non-metric multidimensional scaling (NMDS) plot showing differences in functional traits between sites exposed to environmental imidacloprid (present) and not exposed to environmental imidacloprid (absent) in the Monongahela National Forest (a) and two units of NPS in West Virginia (b). The presence and absence groups were not significantly different in MNF ( $p=0.93)$ or NPS $(p=0.31)$. Dispersal was significantly different between groups in MNF $(p<0.05)$ but was not different between groups in NPS $(p=0.55)$. 

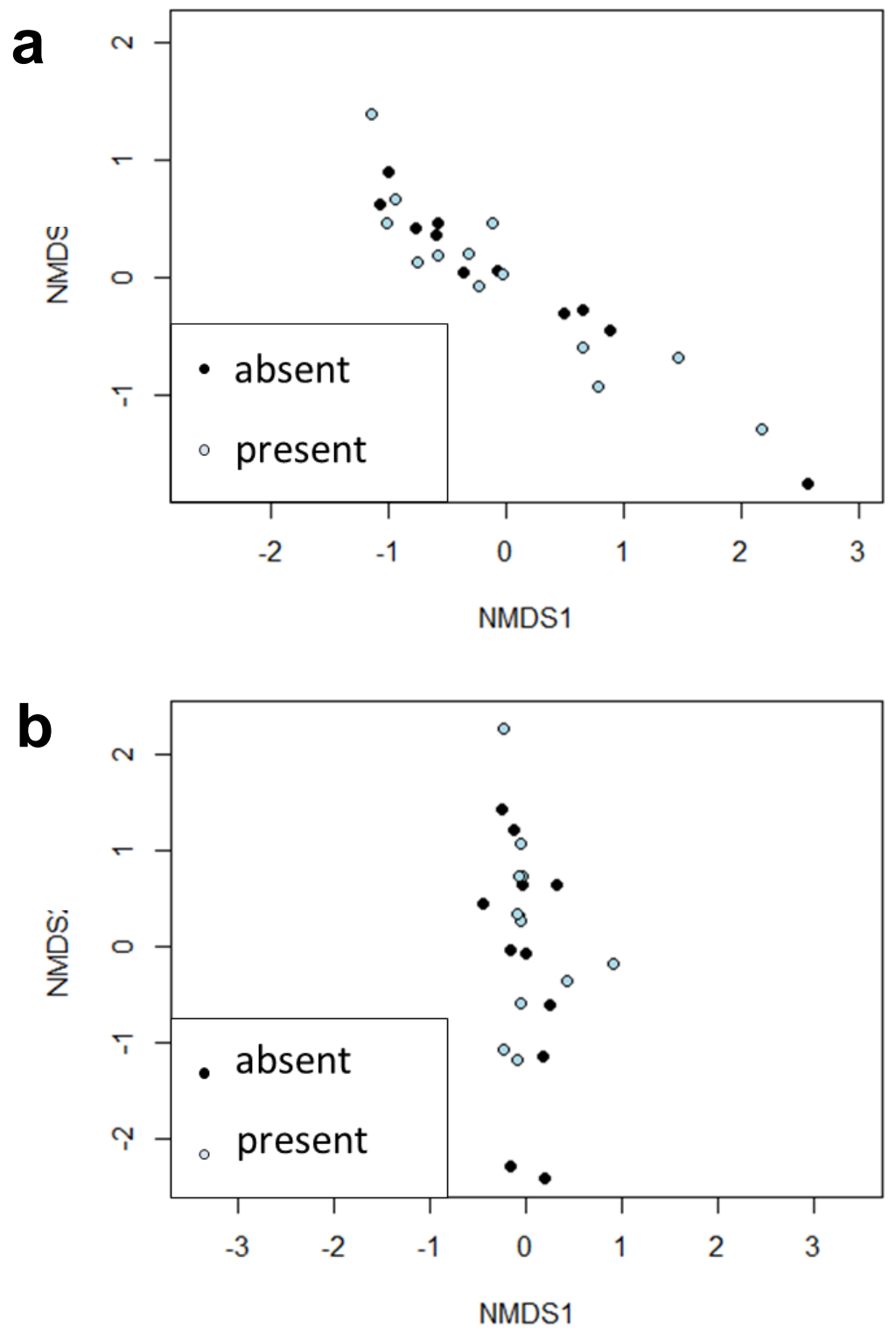

Figure 4-4. Non-metric multidimensional scaling (NMDS) plot showing differences in functional traits between sites with treated trees (present) and without treated trees (absent) in the Monongahela National Forest (a) and two units of NPS in West Virginia (b). The presence and absence groups were not significantly different in MNF $(p=0.93)$ or NPS $(p=0.74)$. Dispersal was not significantly different between groups in MNF $(p=0.74)$ or between groups in NPS $(p=$ $0.37)$. 
Table 4-1. Model selection results for the influence of locality, presence of environmental imidacloprid (Presence), presence of treated trees (Trees), number of imidacloprid applications (Number), and imidacloprid concentration in the water ( $\mathrm{ng} / \mathrm{mL}$; Concentration) on benthic macroinvertebrate community metrics. We used Akaike's Information Criterion corrected for small sample size $\left(\mathrm{AIC}_{c}\right)$ to rank candidate models. The null model is shown as (.) and included only the intercept. Akaike weights are represented as $w_{i}$.

\begin{tabular}{|c|c|c|c|c|c|}
\hline Model & Parameters & $\mathrm{AIC}_{\boldsymbol{c}}$ & $\Delta \mathbf{A I C}_{c}$ & $\mathbf{R}^{2}$ & $\mathbf{W}_{\mathbf{i}}$ \\
\hline \multicolumn{4}{|l|}{ GLIMPSS } & \multicolumn{2}{|c|}{ Pseudo-R ${ }^{2}$} \\
\hline Locality x Presence & 5 & -4.30 & 0.00 & 0.28 & 0.23 \\
\hline Locality x Trees & 5 & -3.60 & 0.70 & 0.23 & 0.16 \\
\hline Locality & 3 & -3.34 & 0.96 & 0.09 & 0.14 \\
\hline (.) & 2 & -2.38 & 1.92 & NA & 0.09 \\
\hline Locality + Presence & 4 & -2.27 & 2.03 & 0.15 & 0.08 \\
\hline Locality + Trees & 4 & -2.10 & 2.20 & 0.14 & 0.08 \\
\hline Locality x Concentration & 5 & -1.85 & 2.45 & 0.14 & 0.07 \\
\hline Locality + Number & 4 & -1.58 & 2.72 & 0.09 & 0.06 \\
\hline Locality + Concentration & 4 & -1.49 & 2.81 & 0.09 & 0.06 \\
\hline Locality x Number & 5 & -0.47 & 3.82 & 0.16 & 0.03 \\
\hline \multicolumn{3}{|l|}{ WVSCI } & \multicolumn{3}{|c|}{ Pseudo-R ${ }^{2}$} \\
\hline Locality x Presence & 5 & -61.29 & 0.00 & 0.18 & 0.22 \\
\hline (.) & 2 & -61.17 & 0.12 & NA & 0.21 \\
\hline Locality & 3 & -60.25 & 1.04 & 0.05 & 0.13 \\
\hline Locality + Concentration & 4 & -59.85 & 1.44 & 0.08 & 0.11 \\
\hline Locality x Trees & 5 & -59.72 & 1.57 & 0.15 & 0.10 \\
\hline Locality x Concentration & 5 & -59.31 & 1.98 & 0.14 & 0.08 \\
\hline Locality + Trees & 4 & -58.15 & 3.14 & 0.05 & 0.05 \\
\hline Locality + Presence & 4 & -58.08 & 3.21 & 0.05 & 0.04 \\
\hline Locality + Number & 4 & -58.02 & 3.27 & 0.04 & 0.04 \\
\hline Locality x Number & 5 & -56.60 & 4.69 & 0.07 & 0.02 \\
\hline \multicolumn{4}{|c|}{ \% Ephemeroptera + Plecoptera + Trichoptera } & \multicolumn{2}{|c|}{ Pseudo-R $^{2}$} \\
\hline Locality & 3 & -19.47 & 0.00 & 0.08 & 0.28 \\
\hline (.) & 2 & -18.95 & 0.52 & NA & 0.22 \\
\hline Locality + Concentration & 4 & -17.30 & 2.17 & 0.08 & 0.10 \\
\hline Locality + Trees & 4 & -17.28 & 2.19 & 0.08 & 0.09 \\
\hline Locality + Number & 4 & -17.07 & 2.41 & 0.08 & 0.08 \\
\hline Locality + Presence & 4 & -17.06 & 2.41 & 0.08 & 0.08 \\
\hline Locality x Trees & 5 & -15.69 & 3.78 & 0.10 & 0.04 \\
\hline Locality x Number & 5 & -15.51 & 3.97 & 0.10 & 0.04 \\
\hline Locality x Presence & 5 & -15.07 & 4.40 & 0.09 & 0.03 \\
\hline Locality x Concentration & 5 & -14.90 & 4.57 & 0.09 & 0.03 \\
\hline \multicolumn{3}{|c|}{ \% Chironomidae + Annelida } & \multicolumn{3}{|c|}{ Pseudo-R ${ }^{2}$} \\
\hline
\end{tabular}




\begin{tabular}{|c|c|c|c|c|c|}
\hline Locality x Presence & 5 & -196.54 & 0.00 & 0.10 & 0.41 \\
\hline Locality $\mathrm{x}$ Trees & 5 & -196.11 & 0.43 & 0.11 & 0.33 \\
\hline Locality + Presence & 4 & -193.08 & 3.46 & 0.06 & 0.07 \\
\hline (.) & 2 & 192.63 & 3.91 & $\mathrm{NA}$ & 0.06 \\
\hline Locality + Trees & 4 & -192.49 & 4.05 & 0.05 & 0.05 \\
\hline Locality & 3 & -191.39 & 5.15 & 0.02 & 0.03 \\
\hline Locality + Concentration & 4 & -189.57 & 6.97 & 0.03 & 0.01 \\
\hline Locality + Number & 4 & -189.56 & 6.98 & 0.03 & 0.01 \\
\hline Locality x Number & 5 & -189.29 & 7.25 & 0.05 & 0.01 \\
\hline Locality $\mathrm{x}$ Concentration & 5 & -188.42 & 8.12 & 0.04 & 0.01 \\
\hline \multicolumn{3}{|l|}{ \% 5 Dominant Genera } & \multicolumn{3}{|c|}{ Pseudo- $^{2}$} \\
\hline Locality x Presence & 5 & -86.91 & 0.00 & 0.36 & 0.98 \\
\hline Locality x Trees & 5 & -79.15 & 7.76 & 0.28 & 0.02 \\
\hline Locality + Presence & 4 & -69.83 & 17.08 & 0.21 & 0.00 \\
\hline Locality x Number & 5 & -67.40 & 19.51 & 0.18 & 0.00 \\
\hline Locality + Trees & 4 & -66.26 & 20.65 & 0.17 & 0.00 \\
\hline Locality $\mathrm{x}$ Concentration & 5 & -61.24 & 25.67 & 0.12 & 0.00 \\
\hline Locality & 3 & -60.20 & 26.70 & 0.08 & 0.00 \\
\hline Locality + Concentration & 4 & -58.21 & 28.70 & 0.08 & 0.00 \\
\hline Locality + Number & 4 & -57.86 & 29.05 & 0.07 & 0.00 \\
\hline (.) & 2 & -51.88 & 35.03 & NA & 0.00 \\
\hline \multicolumn{3}{|l|}{ Genus Richness } & \multicolumn{3}{|c|}{ Adj-R ${ }^{2}$} \\
\hline Locality & 3 & 344.32 & 0.00 & 0.08 & 0.30 \\
\hline Locality + Trees & 4 & 346.10 & 1.79 & 0.08 & 0.12 \\
\hline Locality + Presence & 4 & 346.11 & 1.80 & 0.08 & 0.12 \\
\hline Locality + Concentration & 4 & 346.6 & 2.29 & 0.07 & 0.10 \\
\hline Locality + Number & 4 & 346.64 & 2.33 & 0.07 & 0.09 \\
\hline (.) & 2 & 347.22 & 2.91 & NA & 0.07 \\
\hline Locality x Presence & 5 & 347.26 & 2.94 & 0.08 & 0.07 \\
\hline Locality x Trees & 5 & 347.69 & 3.38 & 0.07 & 0.06 \\
\hline Locality x Concentration & 5 & 348.29 & 3.98 & 0.06 & 0.04 \\
\hline Locality x Number & 5 & 348.78 & 4.46 & 0.05 & 0.03 \\
\hline \multicolumn{3}{|l|}{ Biomass } & \multicolumn{3}{|c|}{$\operatorname{Adj}-R^{2}$} \\
\hline (.) & 2 & 307.56 & 0.00 & NA & 0.31 \\
\hline Locality x Presence & 5 & 308.17 & 0.62 & 0.07 & 0.23 \\
\hline Locality & 3 & 309.21 & 1065 & -0.01 & 0.14 \\
\hline Locality x Trees & 5 & 309.69 & 2.13 & 0.04 & 0.11 \\
\hline Locality + Trees & 4 & 311.05 & 3.49 & -0.02 & 0.05 \\
\hline Locality + Presence & 4 & 311.23 & 3.67 & -0.02 & 0.05 \\
\hline Locality + Number & 4 & 311.45 & 3.89 & -0.03 & 0.04 \\
\hline Locality + Concentration & 4 & 311.55 & 3.99 & -0.03 & 0.04 \\
\hline Locality x Number & 5 & 313.67 & 6.11 & -0.05 & 0.01 \\
\hline Locality x Concentration & 5 & 314.05 & 6.49 & -0.05 & 0.01 \\
\hline
\end{tabular}


Table 4-2. Parameter estimates ( $\beta$ ) and standard errors (SE) for predictor variables for the most parsimonious models (identified in Table 4-2) for each of seven community metrics.

\begin{tabular}{|c|c|c|c|}
\hline Predictor & $\boldsymbol{\beta}$ & $\mathbf{S E}$ & $95 \% \mathrm{CI}$ \\
\hline \multicolumn{4}{|l|}{ GLIMPSS } \\
\hline Locality x Presence & 1.74 & 0.6 & $(0.57-2.91)$ \\
\hline Locality & -1.87 & 0.51 & $(-2.87--0.86)$ \\
\hline Presence & -1.36 & 0.42 & $(-2.18--0.53)$ \\
\hline Intercept & 1.86 & 0.36 & $(0.57-2.91)$ \\
\hline \multicolumn{4}{|l|}{ WVSCI } \\
\hline Locality x Presence & 1.15 & 0.47 & $(0.23-2.06)$ \\
\hline Locality & -1.06 & 0.39 & $(-1.83--0.29)$ \\
\hline Presence & -0.65 & 0.34 & $(-1.31--0.01)$ \\
\hline Intercept & 1.9 & 0.29 & $(1.33-2.48)$ \\
\hline \multicolumn{4}{|c|}{ \% Ephemeroptera + Plecoptera + Trichoptera } \\
\hline Locality & 0.49 & 0.29 & $(-0.07-1.05)$ \\
\hline Concentration & 0.002 & 0.01 & $(-0.01-0.01)$ \\
\hline Intercept & 0.54 & 0.22 & $(0.1-0.97)$ \\
\hline \multicolumn{4}{|c|}{$\%$ Chironomidae + Annelida } \\
\hline Locality x Presence & 1.6 & 0.65 & $(0.32-2.88)$ \\
\hline Locality & -1.56 & 0.55 & $(-2.63--0.49)$ \\
\hline Presence & -1.53 & 0.43 & $(-2.39--0.68)$ \\
\hline Intercept & -1.05 & 0.34 & $(-1.72--0.38)$ \\
\hline \multicolumn{4}{|c|}{ \% 5 Dominant Genera } \\
\hline Locality x Presence & 2.69 & 0.55 & $(1.61-3.78)$ \\
\hline Locality & -2.65 & 0.48 & $(-3.06--1.70)$ \\
\hline Presence & -2.33 & 0.42 & $(1.61-3.78)$ \\
\hline Intercept & 3.33 & 0.39 & $(2.57-4.09)$ \\
\hline \multicolumn{4}{|l|}{ Genus Richness } \\
\hline Trees & -2.01 & 2.66 & $(-7.36-3.34)$ \\
\hline Locality & -6.14 & 2.64 & $(-11.46--0.82)$ \\
\hline Intercept & 22.88 & 2.41 & $(18.03-27.73)$ \\
\hline \multicolumn{4}{|l|}{ Biomass } \\
\hline Locality x Presence & 8.88 & 3.82 & $(1.18-16.58)$ \\
\hline Locality & -4.77 & 3.21 & $(-11.24-1.70)$ \\
\hline Presence & -5.21 & 2.57 & $(-10.39--0.02)$ \\
\hline Intercept & 16.05 & 2.1 & $(11.81-20.28)$ \\
\hline
\end{tabular}




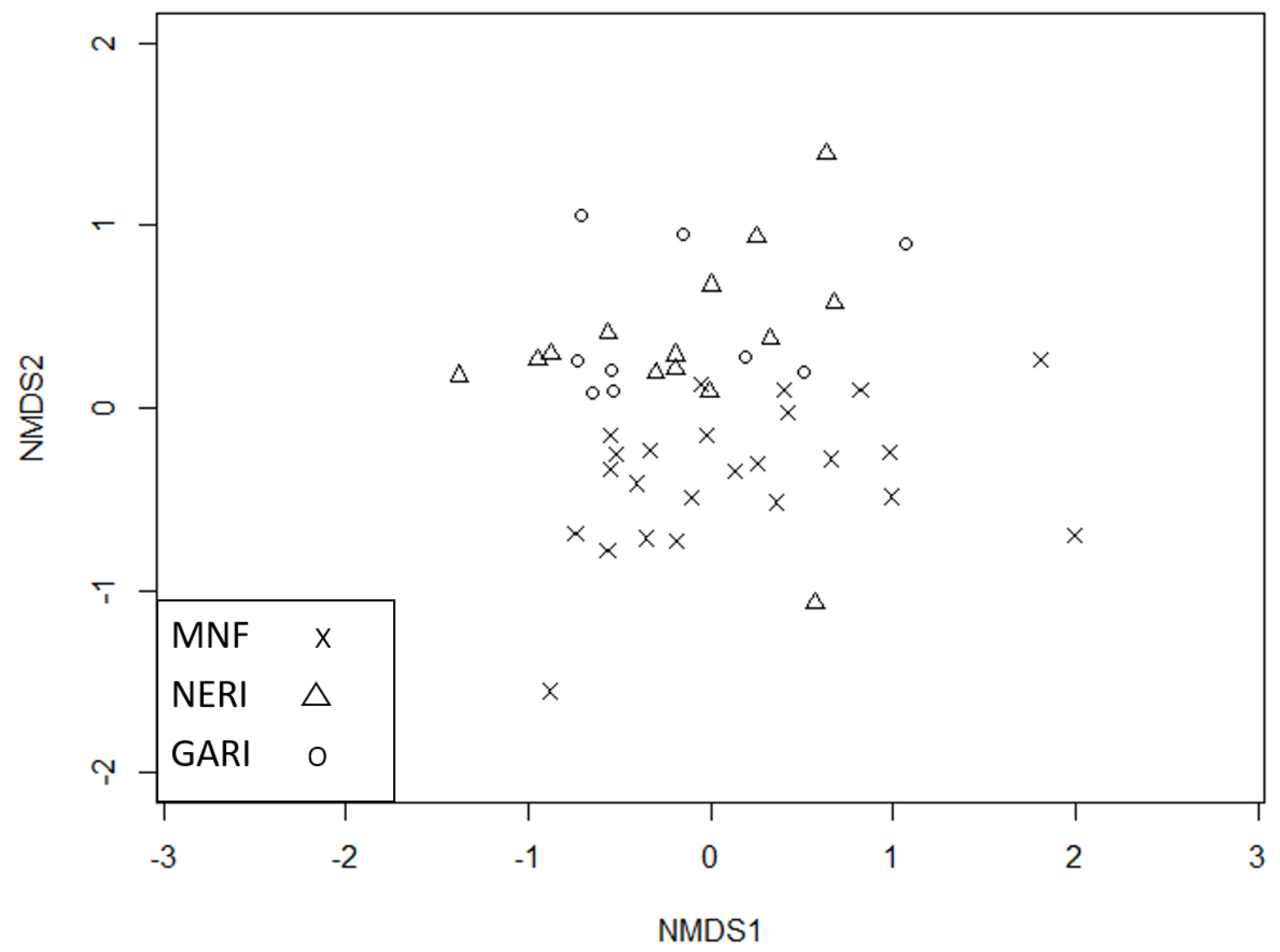

Appendix 4-1. Non-metric multidimensional scaling (NMDS) plots of benthic macroinvertebrate genus abundances for each stream site. Abundances differed based on geographic location between the Monongahela National Forest (MNF) and the NPS locations (Gauley River [GARI] and New River Gorge [NERI]). Stress was 0.216. NPS and MNF sites were significantly different $(p=0.002)$. 
Appendix 4-2. List of functional traits used to categorize benthic macroinvertebrate taxa for functional traits analysis. Functional traits were assigned to each taxon using Poff et al. (2006), the EPA database (U.S. EPA 2012) when appropriate, or the next most similar known taxa.

Semi-voltine
Univoltine
Non-seasonal development
Slow seasonal development
Poor synchronized dispersal
Well synchronized dispersal
Long life
Short life
Very short life
High dispersal
Low dispersal
Strong flyer
Weak flyer
Non-emergent
Common drifter
Rare drifter
High crawling activity
Low crawling activity
Very low crawling activity
Weak swimmer
Free ranging
No armor
Poor armor
Riffle and pool habitat
Riffle habitat
No desiccation ability
Desiccation ability
Non-streamlined
Streamlined
Size medium
Climbing activity
Clinging activity
Swimming activity
Cold water habitat
Cool-warm water habitat
Gilled breathing
Tegument breathing


Appendix 4-3. Site-level values for imidacloprid and indices of biotic integrity used in analyses.

Site locations are in Table 1-1.

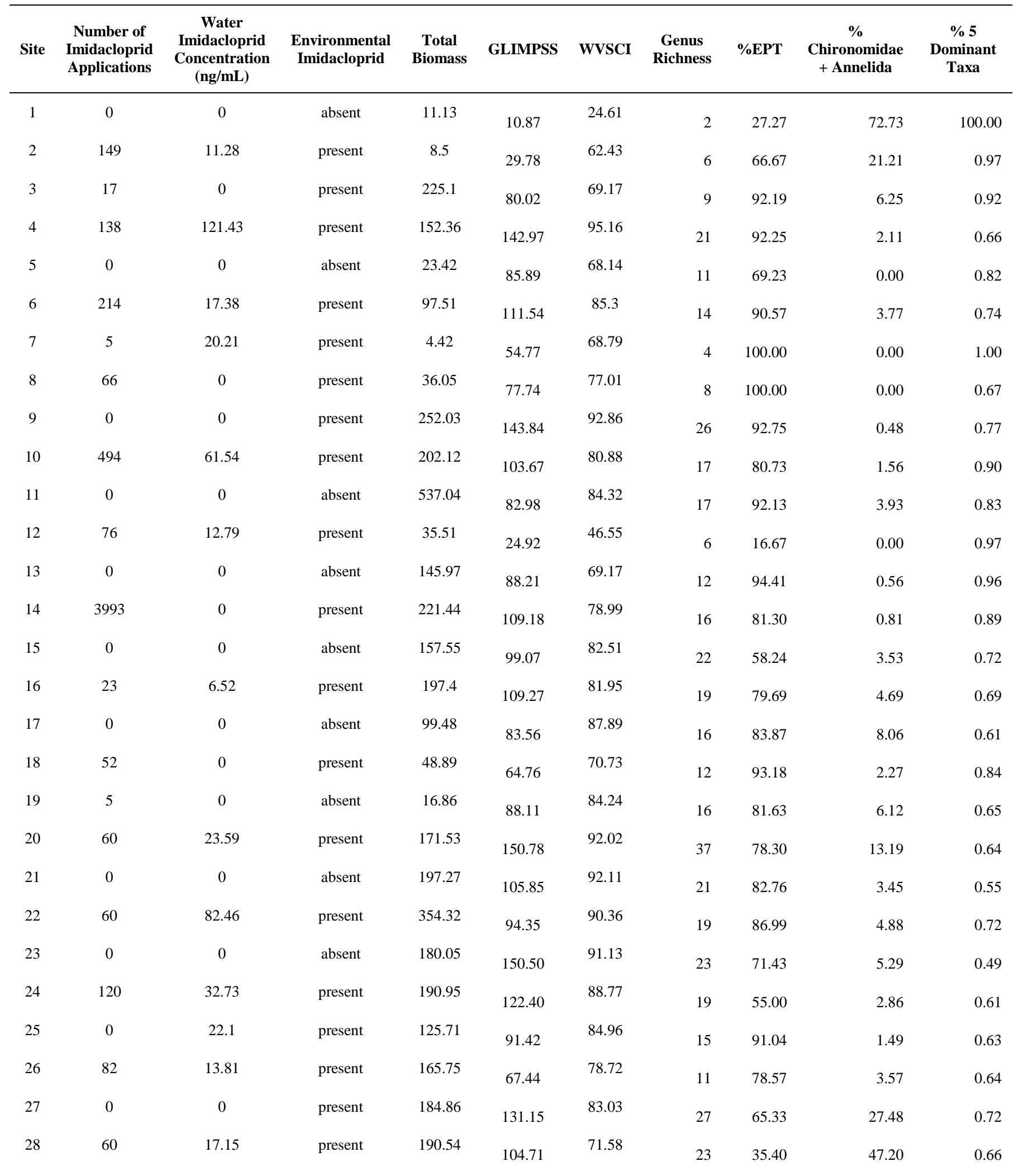




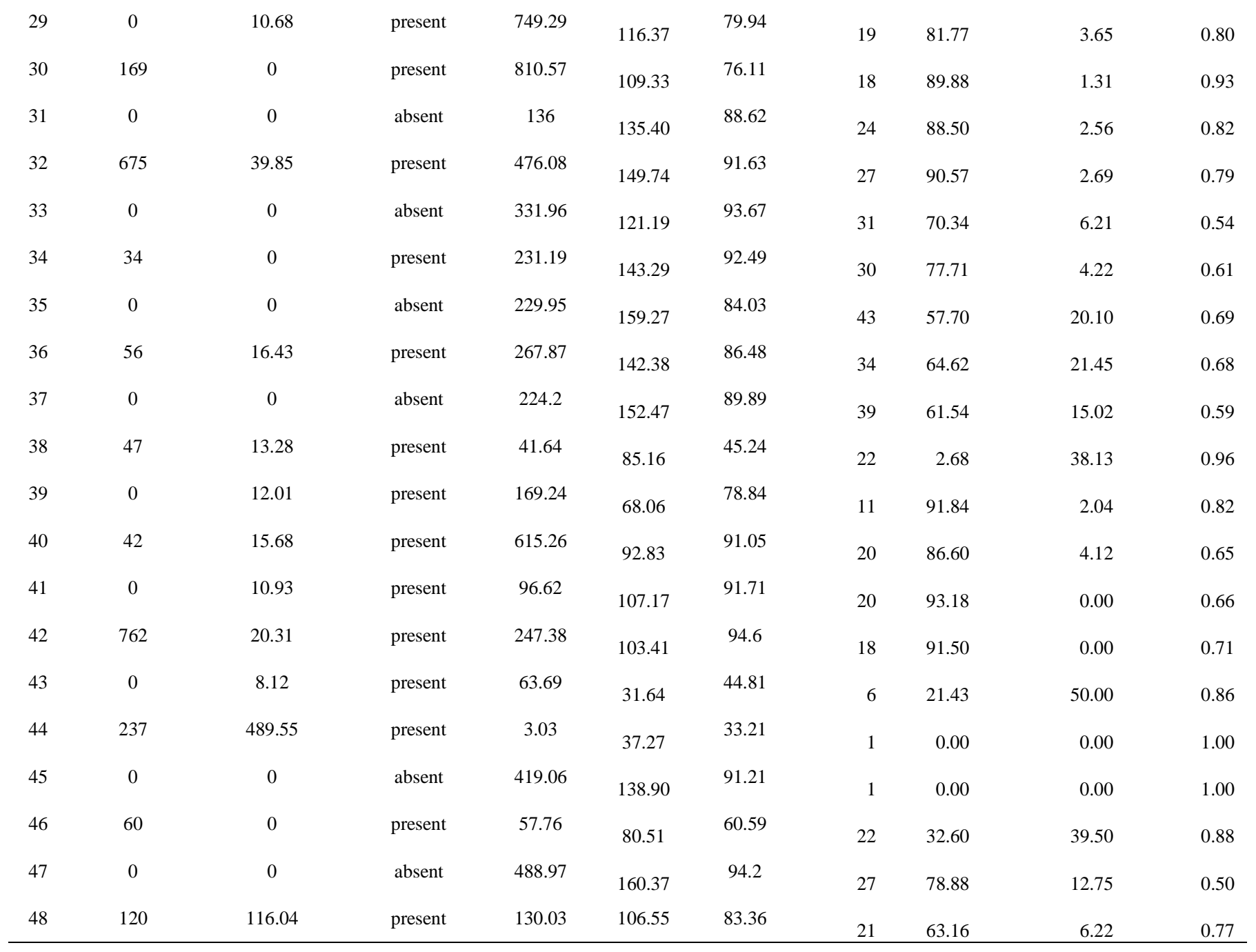


Appendix 4-4. Summary of means \pm SE for seven indicators of benthic macroinvertebrate community integrity for sites without environmental imidacloprid (absent; $\mathrm{n}=8$ ) and with environmental imidacloprid (present; $\mathrm{n}=16$ ) in the Monongahela National Forest (MNF) and for sites without environmental imidacloprid (absent; $n=6$ ) and with environmental imidacloprid (present; $\mathrm{n}=17$ ) in the National Park Service sites (NPS). We defined sites as having environmental imidacloprid if imidacloprid or its metabolites were detected in the water or sediment, or if the stream was adjacent to HWA treatments.

\begin{tabular}{lrrrr}
\hline & \multicolumn{2}{c}{ MNF } & \multicolumn{2}{c}{ NPS } \\
& absent $(\mathbf{n}=\mathbf{8})$ & present $(\mathbf{n}=\mathbf{1 6})$ & absent $(\mathbf{n}=\mathbf{7})$ & present $(\mathbf{n}=\mathbf{1 7})$ \\
Biomass (g) & $271.37 \pm 46.32$ & $138.65 \pm 24.90$ & $168.52 \pm 78.17$ & $271.77 \pm 59.05$ \\
WVSCI & $90.51 \pm 1.17$ & $78.65 \pm 3.19$ & $69.56 \pm 9.61$ & $78.94 \pm 3.75$ \\
GLIMPSS & $134.02 \pm 9.98$ & $100.35 \pm 7.49$ & $83.74 \pm 16.57$ & $96.10 \pm 9.28$ \\
Genus Richness & $25.13 \pm 4.70$ & $20.00 \pm 2.73$ & $14.67 \pm 3.30$ & $16.06 \pm 1.58$ \\
\% EPT & $63.32 \pm 9.64$ & $69.14 \pm 6.72$ & $71.63 \pm 10.61$ & $78.80 \pm 5.71$ \\
\% Chironomidae & $8.86 \pm 2.34$ & $13.66 \pm 3.97$ & $13.88 \pm 11.79$ & $6.16 \pm 2.99$ \\
+Annelida & $62.29 \pm 5.83$ & $73.06 \pm 3.13$ & $85.7 \pm 4.21$ & $80.64 \pm 2.69$ \\
\% 5 Dominant Genera & & & & \\
\hline
\end{tabular}


Appendix 4-5. Scatterplots comparing seven community indices to water imidacloprid concentration $(\mathrm{ng} / \mathrm{mL})$ for 48 sites sampled on MNF and NPS.
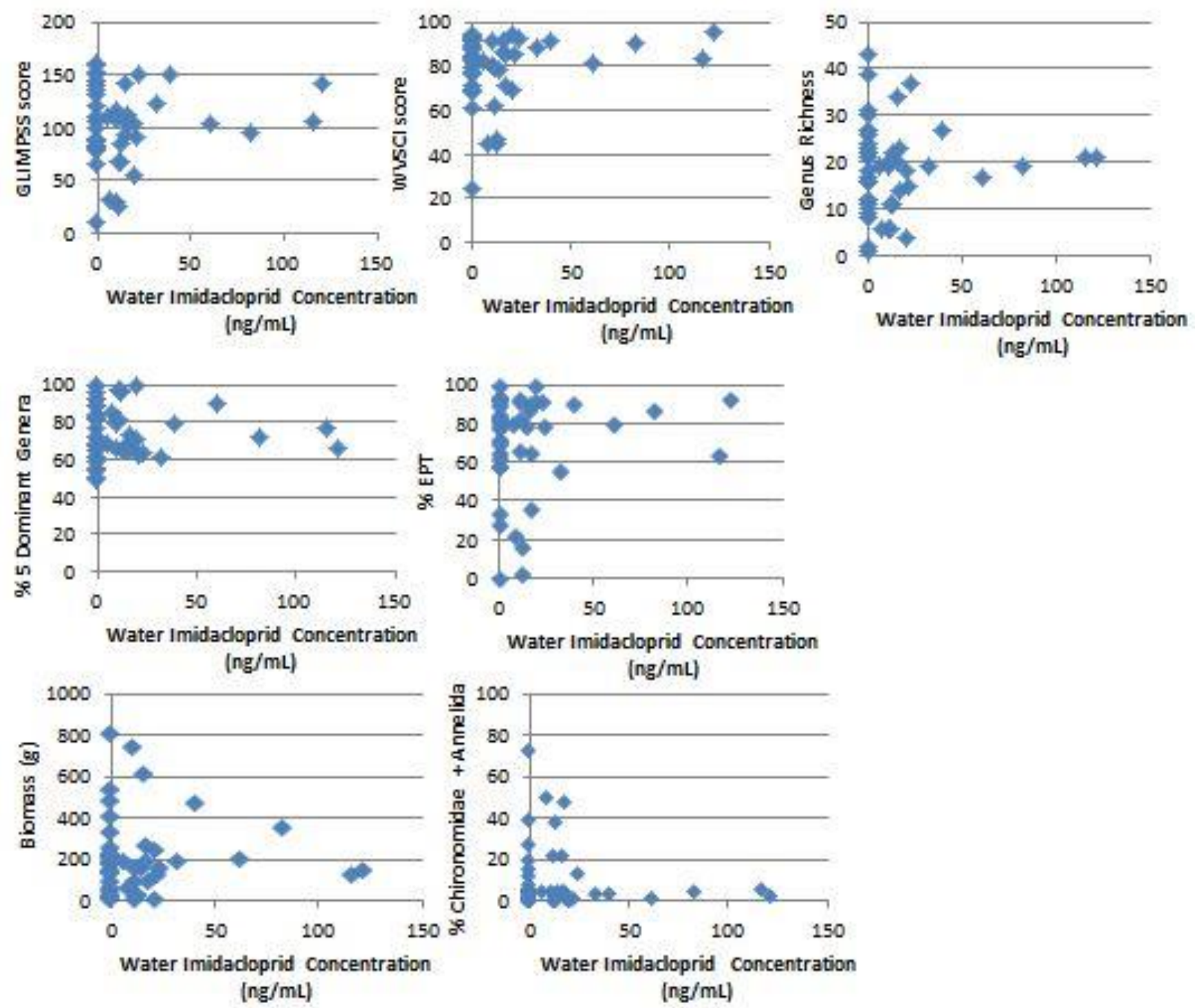
Appendix 4-6. Scatterplots comparing seven community indices to number of imidacloprid applications for 48 sites sampled on MNF and NPS.
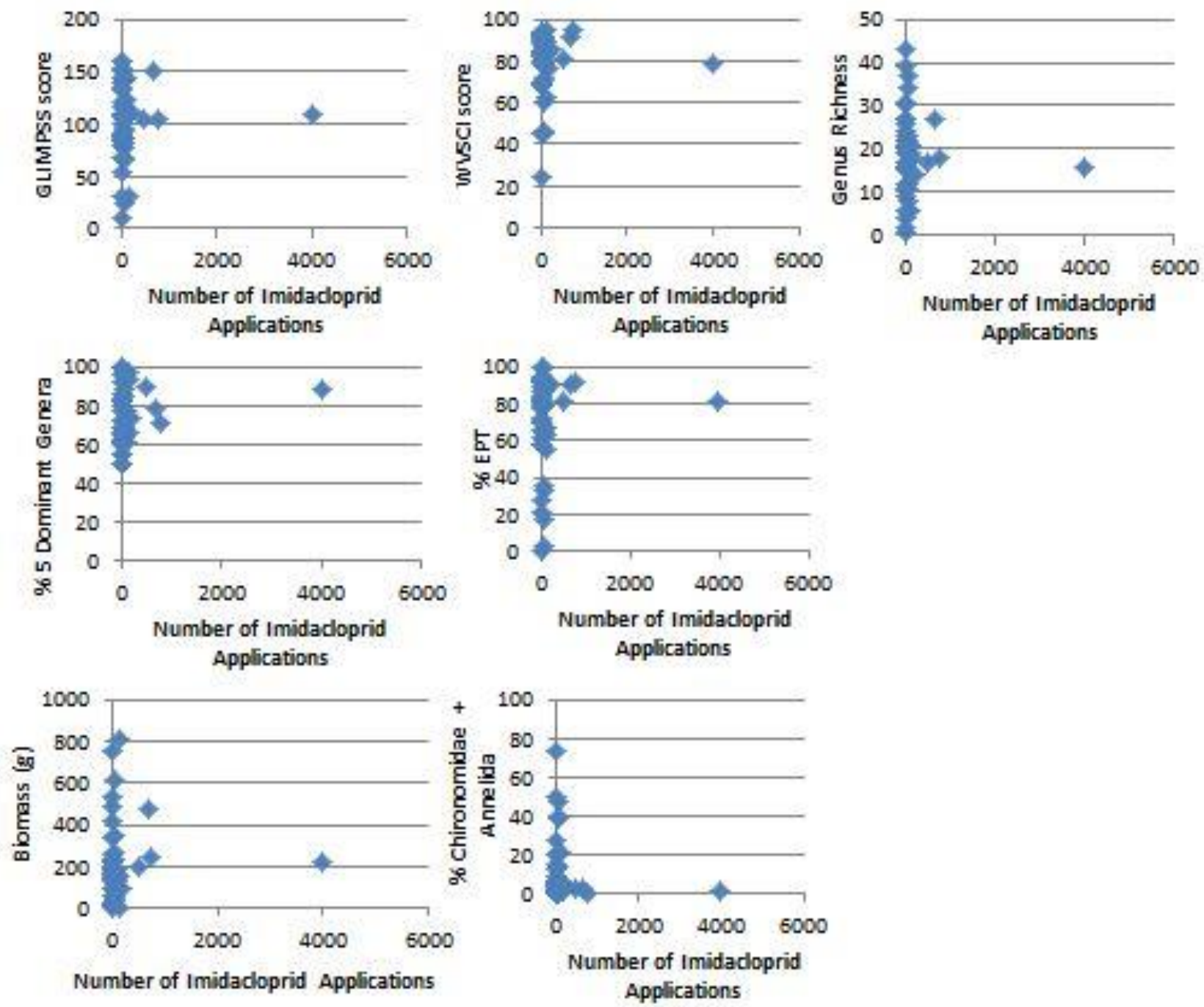